\title{
First systematic study using the variability of the residual colour patterns: the case of the Paleogene Seraphsidae (Mollusca, Gastropoda, Stromboidea)
}

\author{
Bruno CAZE \\ Didier MERLE \\ Jean-Michel PACAUD \\ Jean-Paul SAINT MARTIN \\ Muséum national d'Histoire naturelle, Département Histoire de la Terre, \\ Centre de Recherches sur la Paléobiodiversité \\ et les Paléoenvironnements (CR2P), UMR 7207 du CNRS 8, \\ case postale 38, 57 rue Cuvier, F-75231 Paris cedex 05 (France)
}

Caze B., Merle D., Pacaud J.-M. \& Saint Martin J.-P. 2010. - First systematic study using the variability of the residual colour patterns: the case of the Paleogene Seraphsidae (Mollusca, Gastropoda, Stromboidea). Geodiversitas 32 (3): 417-477.

KEY WORDS Mollusca,

Gastropoda, Stromboidea, Seraphsidae, residual colour patterns,

UV light,

Palaeogene,

Europe,

intraspecific variability,

new species.

\begin{abstract}
This work presents for the first time the application of the residual colour patterns revelead under UV light for the systematic study on Caenozoic seraphsids. The seraphsids species have been previously distinguished on the basis of the shell shape, but this generally bear few diagnostic characters. This study concerns 14 European Palaeogene species belonging, in the previous classification, to the following taxa Seraphs (s.s.) Montfort, 1810, S. (Diameza) Deshayes, 1865, S. (Miniseraphs) Jung, 1974 and Paraseraphs Jung, 1974. The observation of 1400 specimens under UV light allows integrating intraspecific variability. Except for $P$. praecedens $\mathrm{n}$. sp. (Thanetian, oldest occurrence of the genus) and S. subconvolutus (d'Orbigny, 1852) (Rupelian), all species show colour patterns. The bauplan of the fossil colour patterns is very similar to that of the single extant Terebellum terebellum (Linnaeus, 1758), except for Diameza Deshayes, 1865. Taking into account their peculiar pattern and shell shape, Diameza and Miniseraphs are here excluded from Seraphs and raised to genus level, and Miniseraphs is regarded as a subgenus of Diameza. At specific level, the similarity of the colour patterns of S. volutatus (Solander in Brander, 1766), S. olivaceus (Cossmann, 1889) and S. sopitus (Solander in Brander, 1766), do not justify their distinction based on close shell shapes. Considering the colour patterns, we demonstrate that several shell characters, previously used to distinguish Paraseraphs species, are no longer useful for diagnose. Seraphs peterjungi n. sp. (Lutetian, Paris Basin) is distinguished on the basis of the colour pattern and two Seraphs species are in open nomenclature. As for T. terebellum, the colour patterns of S. chilophorus (Cossmann, 1889) and P. tetanus Jung, 1974 are highly variable. Thus, taking into account intraspecific variability, the residual colour patterns represent an important taxonomic tool in addition to the traditional study of the shell shape.
\end{abstract}




\author{
MOTS CLÉS \\ Mollusca, \\ Gastropoda, \\ Stromboidea, \\ Seraphsidae, \\ patrons de coloration \\ résiduels, \\ lumière UV, \\ Paléogène, \\ Europe, \\ variabilité intraspécifique, \\ espèces nouvelles.
}

\begin{abstract}
RÉSUMÉ
Première étude systématique fondée sur la variabilité des motifs colorés résiduels: le cas des Seraphsidae paléogènes (Mollusca, Gastropoda, Stromboidea)

Ce travail propose pour la première fois l'utilisation d'une analyse descriptive des patrons de coloration résiduels révélés sous lumière UV pour le traitement systématique des Seraphsidae cénozoïques. Par le passé, celles-ci avaient été uniquement distinguées à partir de la coquille, bien qu'elle présente assez peu de caractères diagnostiques. Cette étude porte sur 14 espèces du Paléogène d'Europe appartenant, dans la classification précédente, aux taxons Seraphs (s.s.) Montfort, 1810, S. (Diameza) Deshayes, 1865, S. (Miniseraphs) Jung, 1974 et Paraseraphs Jung, 1974. Plus de 1400 spécimens ont été étudiés sous lumière ultraviolette ce qui a permis de bien prendre en compte la variabilité intraspécifique. Exceptés $P$. praecedens $\mathrm{n}$. sp. (Thanétien, plus ancien représentant du genre) et S. subconvolutus (d'Orbigny, 1852) (Rupélien), toutes les espèces montrent des motifs colorés. Le plan d'organisation des patrons de coloration fossiles est très similaire de celui de l'espèce actuelle Terebellum terebellum (Linnaeus, 1758), sauf chez Diameza Deshayes, 1865. Considérant ce motif particulier et la forme de la coquille, Diameza est, ici, exclu du genre Seraphs. Au niveau spécifique, la forte similitude du patron de coloration de S. volutatus (Solander in Brander, 1766), S. olivaceus (Cossmann, 1889) et S. sopitus (Solander in Brander, 1766), aux coquilles très proches, ne justifie pas leur distinction. Plusieurs caractères morphologiques de la coquille, utilisés habituellement pour distinguer les espèces de Paraseraphs, ne peuvent plus être considérés comme diagnostiques au regard des patrons de coloration. Seraphs peterjungi n. sp. (Lutétien, bassin de Paris) est exclusivement décrit grâce au patron et deux espèces de Seraphs sont en nomenclature ouverte. Comme chez T. terebellum, les patrons de coloration de $S$. chilophorus (Cossmann, 1889) et $P$. tetanus Jung, 1974 sont très variables. Ainsi, en tenant compte de la variabilité intraspécifique, les patrons de coloration représentent un outil taxonomique important en complément de l'étude traditionnelle de la forme de la coquille.
\end{abstract}

\section{INTRODUCTION}

Many Recent gastropod families are represented by species having various colour patterns. These patterns can be used as a discriminating criterion for specific recognition or identification (Cox 1969) as for the Cypraeidae Rafinesque, 1815, the Triviidae Troschel, 1863 (Dommergues et al. 2006), the Naticidae Guilding, 1834, the Conidae Fleming, 1822, the Marginellidae Fleming, 1828, the Columbellidae Swainson, 1840, the Volutidae Rafinesque, 1815 (Dockery 1980), the Olividae Latreille, 1825, etc. In the fossil record, shells usually do not show visible colour pat- terns, because the pigments have disappeared or are deteriorated. However, an approach initiated by Olsson in the 1960's (Krueger 1974) enables observation of residual colour patterns on fossil marine shells (Vokes \& Vokes 1968; Cate 1972; Krueger 1974; Hoerle 1976; Hoerle \& Vokes 1978; Dockery 1980; Bouniol 1982; Swann \& Kelley 1985; Kelley \& Swann 1988; Pitt \& Pitt 1992,1993; Merle 2003; Pacaud 2003, 2007; Cluzaud \& Cahuzac 2006a, b; Kase et al. 2008; Merle et al. 2008). These hidden patterns are revealed or enhanced by bleaching the shells in sodium hypochlorite and photographing them under long wave ultraviolet light. Subsequently, 
Systematics of Paleogene Seraphsidae (Mollusca, Gastropoda, Stromboidea)

A
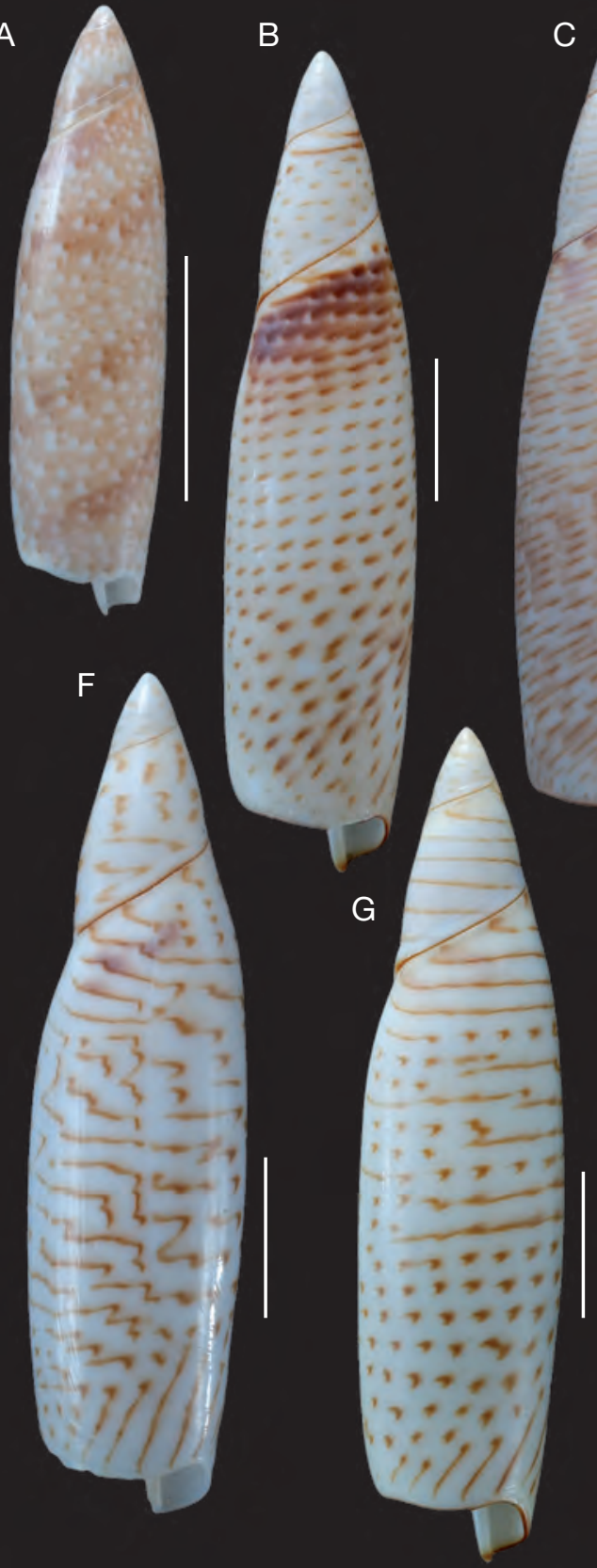

B

C

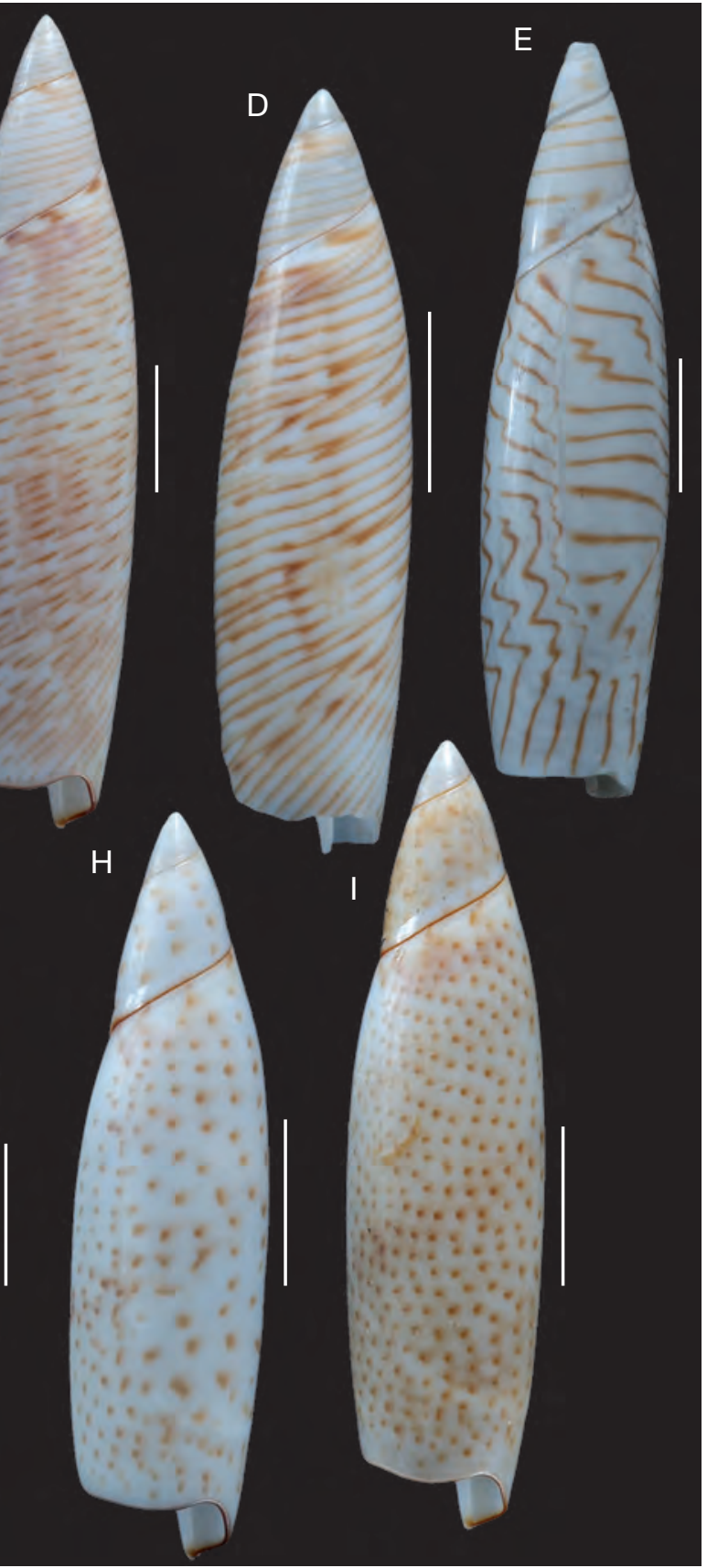

FIG. 1. - Variability of the extant species Terebellum terebellum (Linnaeus, 1758) in dorsal view and normal light: A, T. terebellum form delicatum Kuroda \& Kawamoto, 1961, MNHN IM, Segond Channel, Santo, Vanuatu; B, H, I, T. terebellum form punctulorum (Röding, 1798); C-G, T. terebellum form lineatum (Röding, 1798); B, MNHN IM, Grand Récif Sud, New Caledonia; C, MNHN IM, Lagon Nord, New Caledonia; D, MNHN IM, unknown locality; E, MNHN IM, New Caledonia; F, MNHN IM, Grand Récif Sud, New Caledonia; G, MNHN IM, Atoll de Surprise, New Caledonia; H, MNHN IM, Grand Récif Sud, New Caledonia; I, MNHN IM, Grand Récif Sud, New Caledonia. Scale bars: $10 \mathrm{~mm}$. Photographs by C. Lemzaouda (MNHN).

GEODIVERSITAS • $2010 \bullet 32(3)$

419 
this method has been used by a few authors for the study of Caenozoic gastropods. Most of them only illustrated one or two specimens of some species (e.g., Wilson 1975; Dockery 1977; Swann \& Kelley 1985) and described the residual patterns "as an additional point of interest" (Hoerle 1976) in the framework of the study of a given fauna. Some authors (Krueger 1974; Swann \& Kelley 1985; Kelley \& Swann 1988; Pitt \& Pitt 1993) asserted like Dockery (1980: 3) that "Color patterns in Tertiary molluscs may be a basis for establishing lineages and identifying new species or subspecies". However, they did not use the residual patterns as a taxonomic tool excepting Cate (1972) for the American volutids (Lyriinae Pilsbry \& Olsson, 1954) and recently Kase (2008) for Asiatic potamidids (genus Vicarya d'Archiac \& Aime, 1854). Thus, the use of the residual patterns, as taxonomic tool including the intraspecific variabilty, remains a largely unexplored field for palaeontologists. The present study of the Seraphsidae Jung, 1974 is the first approach using the full potential of this method in order to investigate the systematics of the fossils in this family.

\section{THE CASE OF SERAPHSIDAE}

The Seraphsidae are represented by Caenozoic taxa and by a single extant species Terebellum terebellum (Linnaeus, 1758), living in the Indo-Pacific province. The shells have a smooth surface and few diagnostic characters allowing a distinction between different species. Thus, the fossil species have often been distinguished considering the differences in the shell shape, but, unfortunately, without a study based on modern morphometric methods allowing access to shape variability. Moreover, investigations into the residual colour patterns have never been carried out.

The sole extant species, Terebellum terebellum, could be regarded as the single point of reference in order to better understand the variablility of colour pattern within the family. This species is so variable (Figs $1 ; 2$ ) that ancient authors distinguished nine species. However, Jung \& Abbott (1967) did not recognize these species as valid and individualised only four morphological types. According to Jung (1974), intermediary specimens show that it is impossible to separate one type from another, as distinct species (Figs 1; 2).

In the fossil record, traces of pigmentation are usually not preserved, except on rare perfectly preserved shells of Seraphs volutatus (Solander in Brander, 1766) from the Lutetian of the Paris basin, showing remnants of the colour patterns. Thus, as the distinction of the species is very difficult based on the shell characters, the study of the residual colour patterns using UV light provides an additional complex of characters for the identification of fossil species. However, as seen above with Terebellum terebellum, it is necessary to consider the intraspecific variability of the studied species. Our study is the first one integrating the intraspecific variability of the residual colour patterns thanks to the observation of a huge number of specimens.

\section{DESCRIPTIVE TERMINOLOGY}

The terminology defined by Meinhardt (1998) for the descriptions of the colour patterns of the Recent molluscs has also been used for the descriptions of the fossil residual patterns. In order to clarify these descriptions, a definition of different terms is given below.

Number of levels of residual pigmentation: the patterns can show from 2 to 4 different colours, called by Meinhardt (1998), levels of pigmentation.

Background relative pigmentation: a darker or paler background contrasts with other elements (making) resulting in different morphologies.

Nature of the pattern: the elements constituting the patterns, fluorescent or not, can show various morphologies having different distribution and density.

Patches-Dots (Fig. 3A, B, E): both terms apply to a small area of a colour contrasting sharply with the background. The distinction between the patches and the dots is essentially based on the relative size of the elements. We consider here that patches are larger than dots (see Figure 3).

Spots (Fig. 3C, D): the dots are composed of one or two coloured parts. These parts are called spots. 
Systematics of Paleogene Seraphsidae (Mollusca, Gastropoda, Stromboidea)

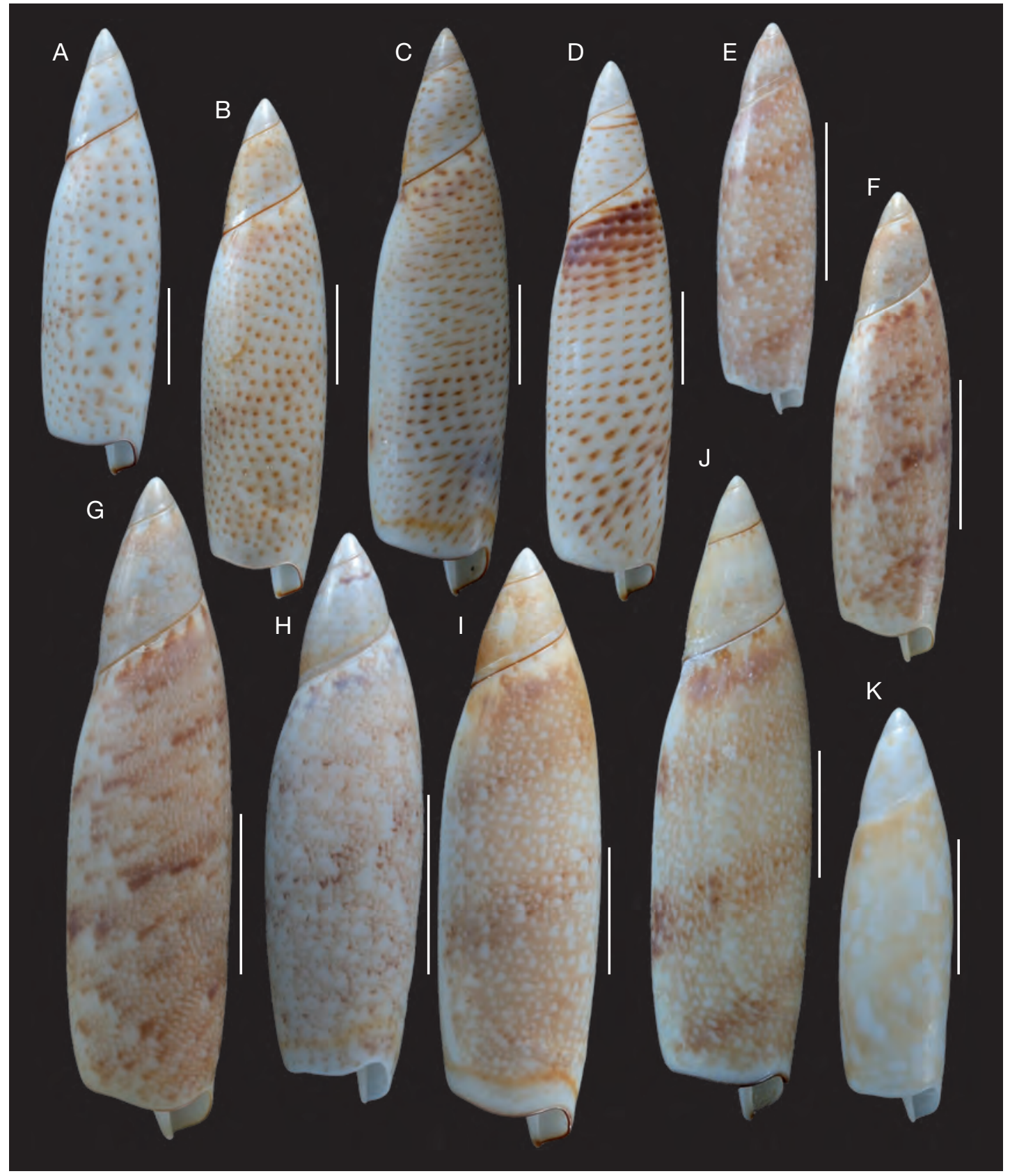

FIG. 2. - Variability of the extant species Terebellum terebellum (Linnaeus, 1758) in dorsal view and normal light: A-D, T. terebellum form punctulorum (Röding, 1798); E, T. terebellum form delicatum Kuroda \& Kawamoto, 1961, MNHN IM, Segond Channel, Santo, Vanuatu; F-J, T. terebellum form nebulosum (Röding, 1798); A, MNHN IM, Grand Récif Sud, New Caledonia; B, MNHN IM, Grand Récif Sud, New Caledonia; C, MNHN IM, Secteur de Balabio, New Caledonia; D, MNHN IM, Grand Récif Sud, New Caledonia; F, MNHN IM, Plateau des Chesterfield; G, MNHN IM, Plateau des Chesterfield); H, MNHN IM, Aésé Island, Santo, Vanuatu; I, MNHN IM, Baie des Citrons, Nouméa, New Caledonia; J, MNHN IM, Quatre Bancs de l'Ouest, lagoon of Nouméa, New Caledonia; K, T. terebellum, MNHN IM, Plateau des Chesterfield. Scale bars: $10 \mathrm{~mm}$. Photographs by C. Lemzaouda (MNHN).

GEODIVERSITAS • $2010 \bullet 32(3)$

421 
Lines-Stripes (Fig. 4A, B): both terms apply to any elongated (object) area or space which is axially or spirally continuous on the whole shell. The distinction between lines and stripes is based on the relative width of these elements. We consider that lines are narrower than stripes. Both elements can be spiral or axial (Fig. 4A, B) and often result from the coalescence of dots or patches.

Segments (Fig. 4D): the segments are short elongated strokes, generally resulting from the coalescence of dots or patches. They can be spiral or axial.

Rows (Fig. 4C): the rows are axial or spiral alignments of dots, patches or segments.

\section{MATERIAL}

The studied material represents about 1400 specimens from 61 fossiliferous sites of the French Palaeogene (Paris and Aquitan basins, Loire-Atlantique and Cotentin). It mainly comes from the Collection de Paléontologie and from the Collection de Malacologie of the Muséum national d'Histoire naturelle of Paris. The detailed list is given in Appendices 1,2 .

\section{METHOD}

As mentioned above, the residual shell pigmentation may be revealed or enhanced by bleaching specimens in sodium hypochlorite then directly exposing those under long wave UV light (Vokes \& Vokes 1968; Dockery 1980; Swann \& Kelley 1985). In this study, the residual patterns have been observed thanks to the procedure defined by Merle et al. (2008). First, the samples are placed in a bath of concentrated sodium hypochlorite for 24 hours. After the bath, they are carefully washed with water. Second, most of the patterns are revealed by an exposure under UV light emitting a wavelength of $3600 \AA$ (Merle 2003).

According to Krueger (1974) refering to Olsson: "When colour patterns fluoresce under UV light, they appear to the human eye as photographic negatives of the colour pattern on a modern shell". Thus, a negative of the picture may give information about the true relationship between a residual colour pat- tern and a live animal's shell. The negative has a dark colour pattern on a lighter background and can be used as a lantern slide to demonstrate how the fossil shell looked when the animal was alive (Fig. 5C, F). In the present work, the shells illustrated under UV light are generally presented without negative treatment. In order to show how the colour pattern was when the animal was alive, a negative treatment is sometimes given (Figs 5C, F; 11F; 16K; 30C).

\section{ABBREVIATIONS}

BMNH The Natural History Museum, Department of Palaeontology, London;

MHNG Muséum d'Histoire Naturelle, département de Géologie et de Paléontologie, Geneva;

MHNN Muséum d'Histoire naturelle de Nantes;

MNHN Muséum national d'Histoire naturelle, collection de Paléontologie, Paris;

IM Muséum national d'Histoire naturelle, collection d'invertébrés marins (mollusques), Paris;

NMB Naturhistorisches Museum, Basel;

UBT université Bordeaux1, Talence;

UCBL université Claude Bernard, UFR Sciences de la Terre, Lyon 1.

\section{RESULTS}

Before presenting the systematic treatment, it is important to stress that the inovation of this work is to have a sufficiently abundant material displaying residual colour pattern to allow the study of the intraspecific variability. Based on 1400 specimens, almost $90 \%$ of the material show positive results under UV light (Table 1). For the various species, the number of specimens observed differs considerably. Among the 14 fossil species, six species are represented by more than 30 specimens, among which four are represented by more than 100 specimens (between 117 and 494 specimens). These samples allow a precise and faithful idea of real variability. For the other species, the number of specimens is lower.

\section{SYSTEMATIC PALEONTOLOGY}

Order LITTORINIMORPHA

Golikov \& Starobogatov, 1975

Superfamily STROMBOIDEA Rafinesque, 1815 


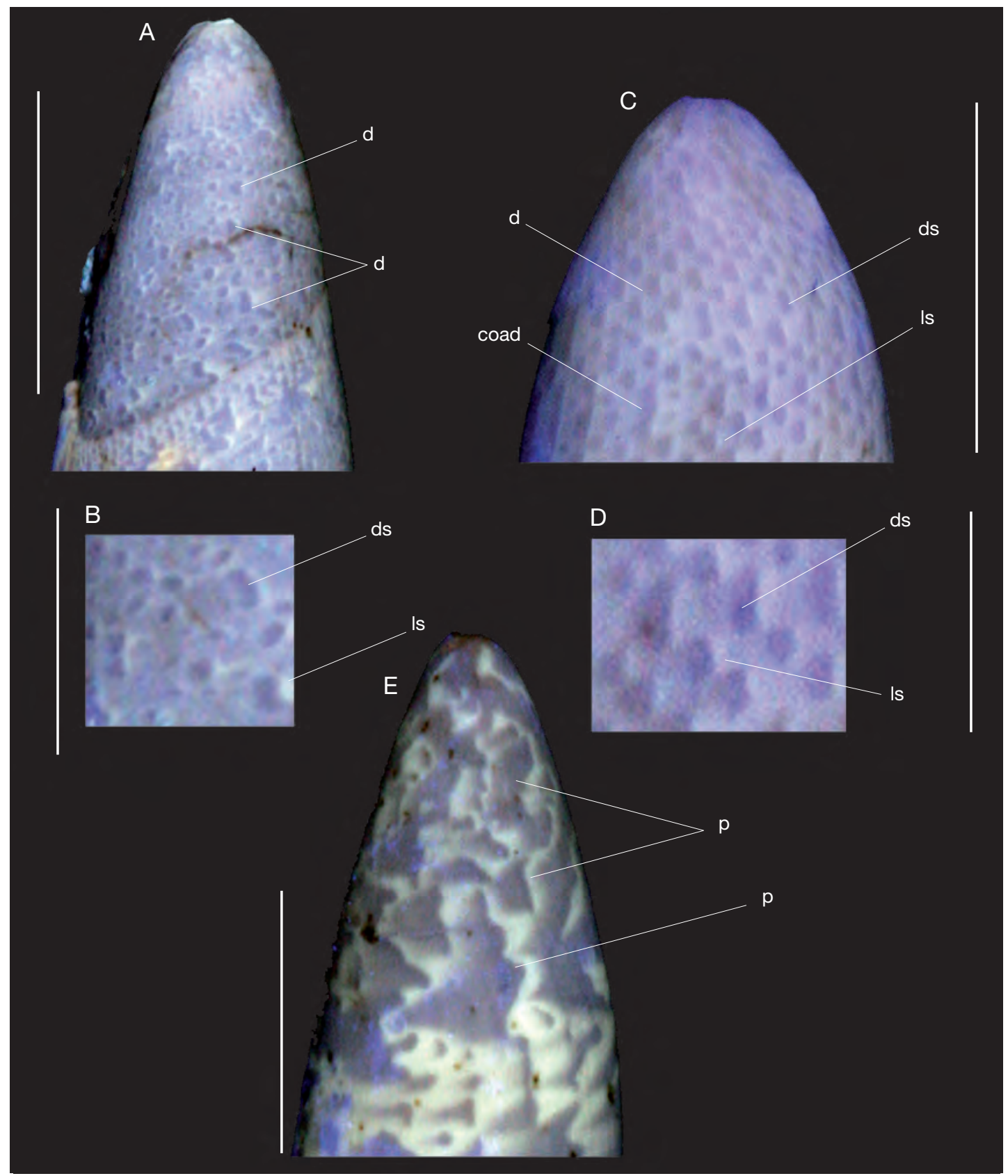

FIG. 3. - Descriptive terminology of the residual colour patterns of the Seraphsidae Jung, 1974: A, B, Paraseraphs placitus Jung, 1974, MNHN A28963 (Ballot coll.), Grignon, Yvelines, France, Lutetian; A, apical part; B, detailed view of the dots; C, D, Seraphs volutatus (Solander in Brander, 1766), MNHN A28873, Grignon, Lutetian; C, apical part; D, detailed view of the dots; E, S. chilophorus (Cossmann, 1889), MNHN A28922 (leg. Pacaud), Fercourt, Oise, France, Lutetian (apical part). Abbreviations: coad, coalescence of dots; d, dot; ds, darker spot; Is, lighter spot; p, patch. All pictures taken under UV light. Scale bars: A, C, E, 5 mm; B, D, 2 mm. Photographs by C. Lemzaouda (MNHN). 


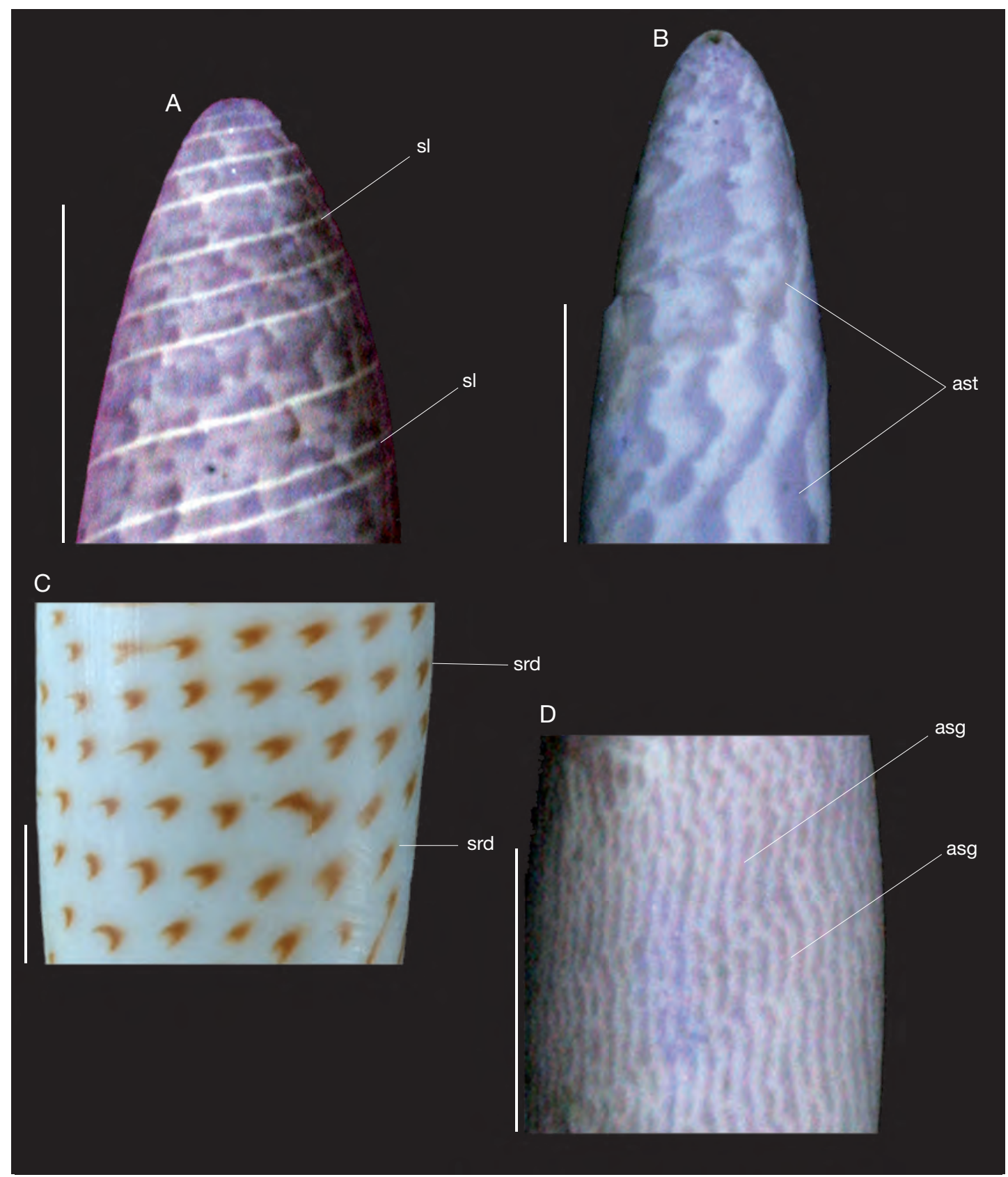

FIG. 4. - Descriptive terminology of the residual colour patterns of the Seraphsidae Jung, 1974: A, paratype of Seraphs peterjungi n. sp. (apical part), MNHN A28931 (leg. Pacaud), Chaussy (Les Garennes), Val d'Oise, France, Lutetian; B, Paraseraphs tetanus Jung, 1974 (apical part), MNHN A28958 (Faullummel coll.), Saint-Gobain, Aisne, France, Ypresian (Cuisian); C, Terebellum terebelIum (Linnaeus, 1758) (median part), MNHN IM, Atoll de Surprise, New Caledonia, Recent; D, Paraseraphs tetanus (median part), MNHN A28943, Cuise-Lamotte (Butte-des-Usages), Oise, France, Ypresian (Cuisian); A, B, D, under UV light; C, in normal light. Abbreviations: asg, axial segment; ast, axial stripes; sl, spiral line; srd, spiral row of dots. Scale bars: $5 \mathrm{~mm}$. Photographs by C. Lemzaouda (MNHN). 


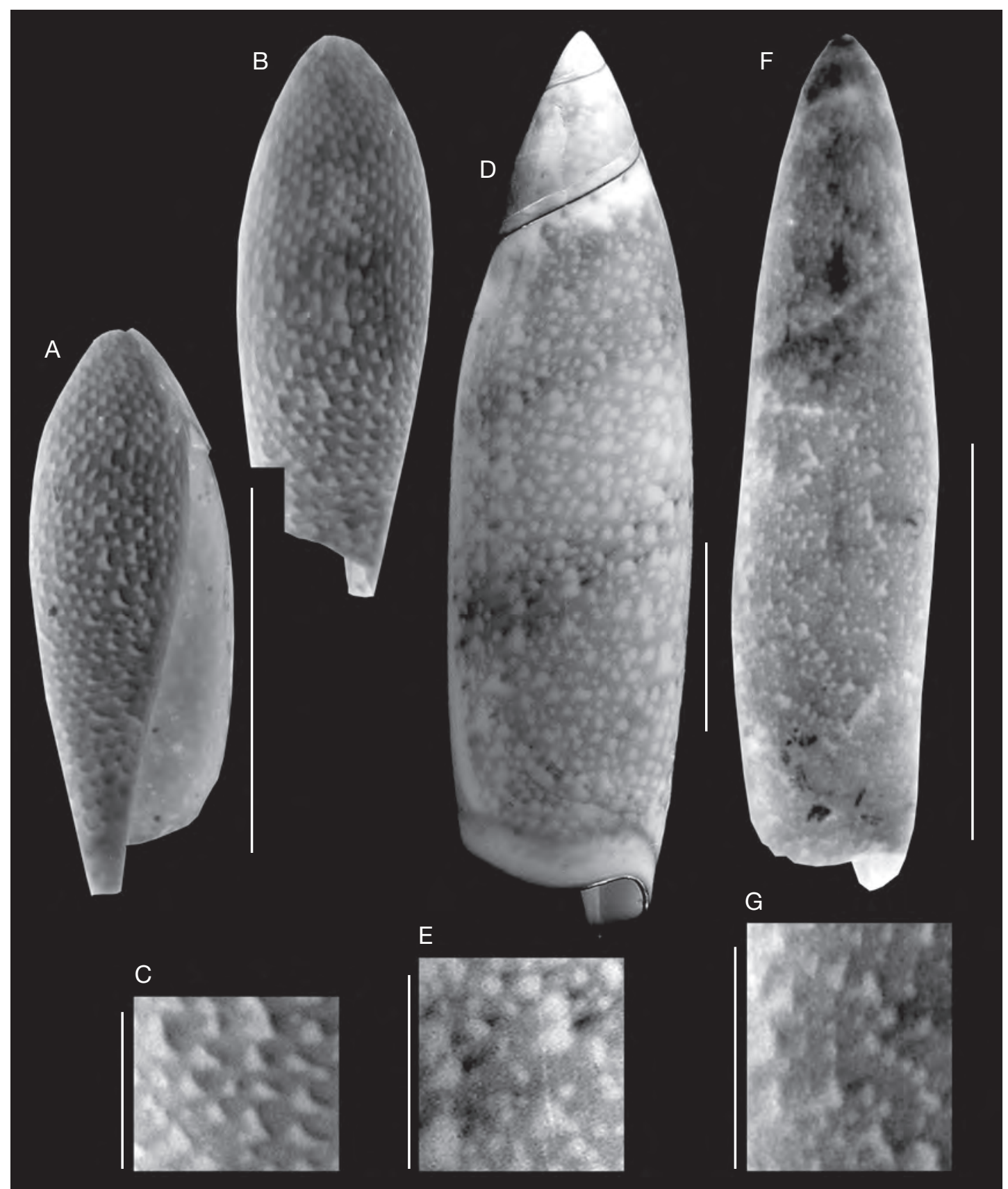

FIG. 5. - Comparison between the colour patterns of fossil and Recent Seraphsidae Jung, 1974: A-C, Seraphs volutatus (Solander in Brander, 1766), MNHN A28873, Grignon, Yvelines, France, Lutetian; A, ventral view; B, dorsal view; C, detailed view of the dots; D, E, Terebellum terebellum (Linnaeus, 1758), MNHN IM, Baie des Citrons, Nouméa, New Caledonia, Recent; D, dorsal view; E, detailed view of the dots; F, G, Paraseraphs placitus Jung, 1974, MNHN A29168 (leg. Pacaud), Chaussy, Val d'Oise, France, Lutetian; F, dorsal view; G, detailed view of the dots; A-C, F, G, under UV light in negative view; D, E, in normal light. Scale bars: A, B, D, F, 10 mm; C, G, 2 mm; E, 5 mm. Photographs by C. Lemzaouda (MNHN). 
TABLE 1. - Comparison between positive and negative results among the studied material.

\begin{tabular}{|c|c|c|c|c|}
\hline Species & $\begin{array}{l}\text { Total number } \\
\text { of specimens }\end{array}$ & $\begin{array}{c}\text { Positive } \\
\text { under UV light }\end{array}$ & $\begin{array}{c}\text { Negative } \\
\text { under UV light }\end{array}$ & Percentages \\
\hline Seraphs volutatus (Solander in Brander, 1766) & 562 & 494 & 68 & 87.9 \\
\hline Seraphs sopitus (Solander in Brander, 1766) & 15 & 11 & 4 & 73.3 \\
\hline Seraphs olivaceus (Cossmann, 1889) & 22 & 20 & 2 & 90.9 \\
\hline Seraphs leukoleptus Jung, 1974 & 5 & 4 & 1 & 80 \\
\hline Seraphs chilophorus (Cossmann, 1889) & 163 & 160 & 3 & 98.16 \\
\hline Seraphs peterjungi n. sp. & 24 & 24 & 0 & 100 \\
\hline Seraphs subconvolutus (d’Orbigny, 1852) & 14 & 0 & 14 & 0 \\
\hline Diameza (Miniseraphs) eratoides (Cossmann, 1889) & 36 & 28 & 8 & 77.8 \\
\hline $\begin{array}{l}\text { Diameza (Miniseraphs) isabella } \\
\text { (Bernay in Deshayes, 1865) }\end{array}$ & 132 & 117 & 15 & 88.6 \\
\hline Diameza (s.s.) fragilis (Defrance, 1825) & 41 & 31 & 10 & 75.6 \\
\hline Paraseraphs tetanus Jung, 1974 & 319 & 304 & 15 & 95.3 \\
\hline Paraseraphs placitus Jung, 1974 & 77 & 66 & 11 & 85.7 \\
\hline Paraseraphs armoricus (Vasseur, 1882) & 4 & 4 & 0 & 100 \\
\hline Paraseraphs praecedens n. sp. & 1 & 0 & 1 & 0 \\
\hline Total & 1415 & 1263 & 152 & 89.3 \\
\hline
\end{tabular}

Family SERAPHSIDAE Jung, 1974

Genus Seraphs Montfort, 1810

TYPE SPECIES. - Terebellum convolutum Lamarck, 1802 (= Bulla volutata Solander in Brander, 1766) by original designation. Lutetian, Paris Basin.

\section{Seraphs volutatus}

(Solander in Brander, 1766)

(Figs 5A, B, E; 6A-E; 7; 8)

Bulla volutata Solander in Brander, 1766: 34, pl. 6, fig. 75 .

Terebellum convolutum Lamarck, 1798: pl. 360, fig. 2 (nomen nudum).

Terebellum convolutum Lamarck, 1802: 390, no. 1, vélin 2, fig. 7a, b; 1805: 225, 226, pl. 2 [44], fig. 3a, b; 1810: 302, no. 2; 1816: pl. 360, fig. 2 ; 1822: 411, no. 2 ; 1823 : pl. 2, fig. 3a, b. - de Roissy 1804: 425-426. - Bory de Saint-Vincent 1826: 165, pl. 360, fig. 2; 1827: 165, pl. 360, fig. 2. - de Blainville 1827: pl. 27, fig. 2, 2a. Deshayes \& Milne-Edwards 1844: 585, no. 2. — Pictet 1855: pl. 64, fig. 1.

Terebellum sopitum - d'Orbigny 1850: 352, no. 263 partim. - Lowry et al. 1866: pl. 3. - Cossmann 1907: 254, fig. 3. - Bosatta et al. 1973: 190, pl. 1, figs 8, 9. Non Bulla sopita Solander in Brander, 1766.
Terebellum (Seraphs) sopitum-Cossmann 1901: 89, pl. 15, fig. 5. - Glibert 1933: 58; 1963: 40. — Korobkov 1955:260, pl. 57, fig. 4. Non Bulla sopita Solander in Brander, 1766.

Seraphs convolutus - de Montfort 1810: 375, 376, 1 fig. Defrance 1827: 490. — Wood 1829: 7, pl. 6, fig. 75.

Terebellum (Seraphs) convolutum - Fischer 1884: 673, fig. 433. - Cossmann 1904: 46, pl. 1, fig. 1. - Cossmann \& Pissarro 1911: pl. 31, fig. 158-2. - Wenz 1940: 938, fig. 2742.

Terebellum (Seraphs) sopitum var. convoluta - Cossmann 1889: 96-97; 1898: 341, pl. 7, fig. 35.

Seraphs sopitus - Jung 1974: 16-21, pl. 1, figs 1-19; pl. 2, figs 1-8; pl. 3, figs 1-9; pl. 4, figs 1-13, text-fig. 11. —Dolin et al. 1980: 28. - Savazzi 1991: 324, fig. 13F. Non Bulla sopita Solander in Brander, 1766.

Seraphs volutatus - Le Renard 1992: 6. — Le Renard \& Pacaud 1995: 112. — Pacaud \& Le Renard 1995: 162. — Pacaud 2008: 724, fig. 2E, F.

TYPE LOCALITY. — Hordwell (England), Bartonian (Middle Eocene).

TYPe MATERIAL. - Bulla volutata Solander in Brander, 1766: the single preserved syntype (BMNH GG 21010) has been selected unambiguously by Jung (1974: 18) as lectotype: "the type specimen of Bulla volutata Solander in Brander (1766, p. 34, pl. 6, fig. 75)". According to article 74.5 of the ICZN (1999) this mention, made before 2000, constitutes a valid lectotype designation. 


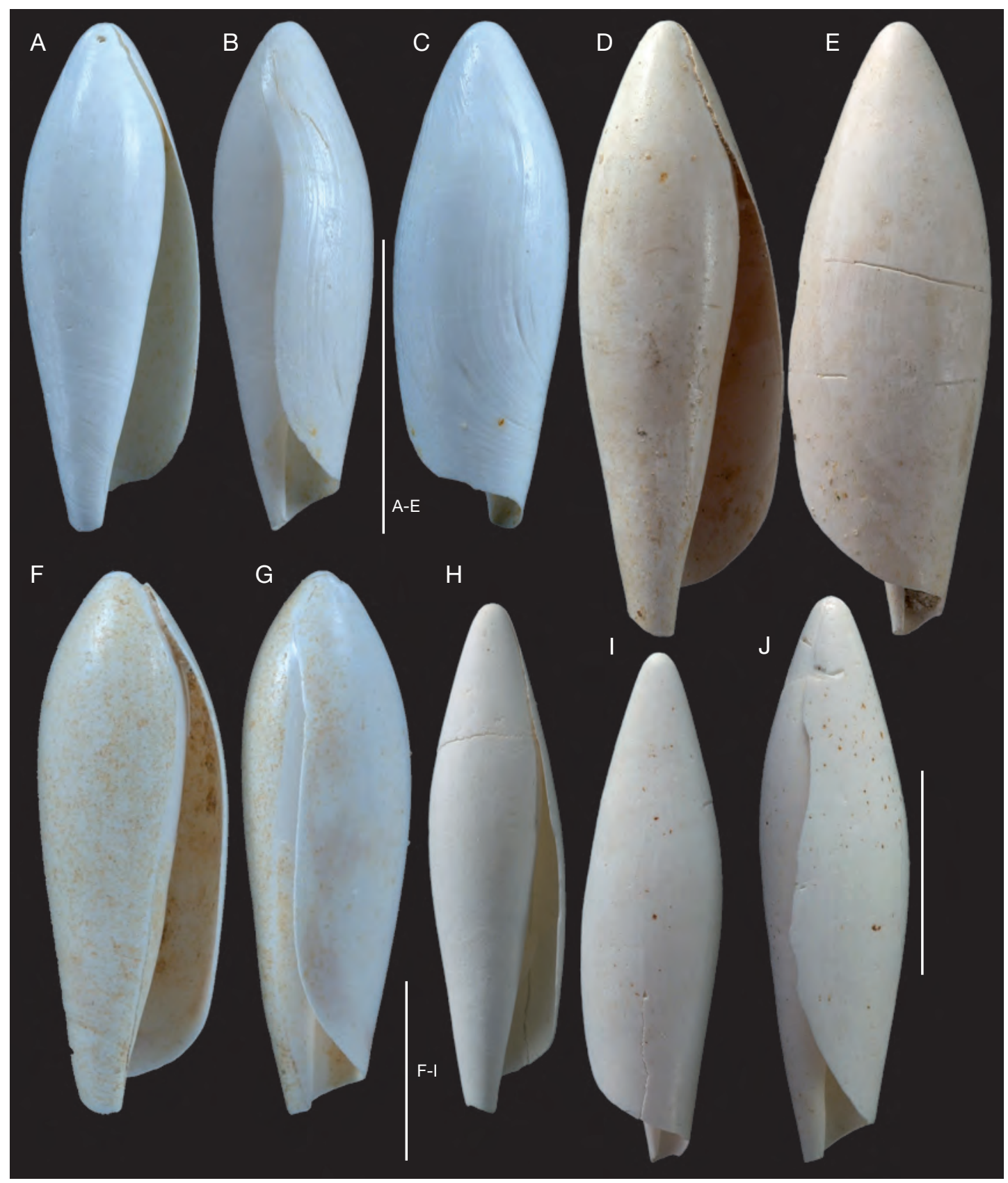

FIG. 6. - Seraphs Montfort, 1810 shells in normal light: A-E, S. volutatus (Solander in Brander, 1766); A-C, MNHN A28776 (ex Galerie de Zoologie coll.), Grignon, Yvelines, France, Lutetian; A, ventral view; B, labral view; C, dorsal view; D, E, lectotype of Terebellum convolutum Lamarck, 1802, MNHN B70325 (Lamarck coll.), Grignon, Lutetian; D, ventral view; E, dorsal view; F, G, S. sopitus (Solander in Brander, 1766), MNHN A28778 (Faullummel coll.), Le Limon, Seine-et-Marne, France, Bartonian; F, ventral view; G, labral view; H-J, S. olivaceus (Cossmann, 1889); H, I, MNHN A28577 (Ledon coll.), Chaussy (Les Garennes), Val d'Oise, France, Lutetian; H, ventral view; I, dorsal view; J, MNHN A29225, labral view (Ledon coll.), Chaussy (Les Garennes), Lutetian. Scale bars: $10 \mathrm{~mm}$. Photographs by $\mathrm{C}$. Lemzaouda (MNHN). 
Terebellum convolutum Lamarck, 1802: lectotype (MNHN B70325, Lamarck coll.) selected here from 3 syntypes from the Lutetian of Grignon (Yvelines); 2 paralectotypes (MNHN A28775, Lamarck coll.).

Other material eXamined. - See Appendix 1.

\section{DESCRIPTION}

Shells

Shell up to $75 \mathrm{~mm}$ in height and $22 \mathrm{~mm}$ in diameter, slightly inflated with short and blunt to somewhat acute apex (Jung 1974). Aperture long and narrow. Callus of the inner lip very thin and rarely preserved except on some "gerontic" shells. Columella almost straight near the base, or rarely bent in some big shells. Outer lip very thin, not thickened, sinuous for the whole height and extending to the apex (Fig. 6B). Siphonal notch moderately deep on the dorsal side of the shell. No sculpture on the surface of the shell.

\section{Colour pattern}

According to Jung (1974), perfectly preserved specimens from the Lutetian of Paris Basin show, in normal light, many small and irregular dots which compose the residual colour pattern.

Under UV light, the colour pattern consists of numerous small dots on a lighter background (Fig. 7). These dots, variable in size, show two levels of residual pigmentation (Fig. 7G). The first one consists of triangle-like spots, darker than the background. The apex of these spots is directed towards the growing edge. The second one consists of spots with a fuzzy border, white, fluorescent under UV light and directed towards the inner lip. They are adjacent to the base of the dark spots. Light spots are variable in shape and size, but they are usually narrower than the dark spots (Fig. 7A-D, G-I). These two components form the dots. Dot density is generally more important on the apical part of the shell. They often form sinuous, axial rows nearly parallel to the edge of growth (Fig. 7A, B). The space between these rows is narrow on the apex and broader on the median and basal parts of the shell.

\section{VARIABILITY OF THE COLOUR PATTERN}

The background is generally light, but sometimes shows large and diffuse darker areas (Fig. 7H, I).
The density of dots is very variable. Some shells have a few large dots and their axial rows are not clearly defined. On other shells, the density of dots is so great that their coalescence may hide the original background. Some specimens strongly coalescent show very few isolated dots. Juvenile specimens often show proportionally bigger dots (Fig. 7E, F). Sometimes the relative size of the light spot is greater than the dark triangular spot (Fig. 7E, F).

\section{STRATIGRAPHIC EXTENSION}

Several specimens (Fig. 8) collected in Sapicourt (Marne, France) constitute the new oldest occurence of the species (Ypresian [Cuisian]).

\section{Seraphs sopitus (Solander in Brander, 1766) (Figs 6F, G; 9)}

Bulla sopita Solander in Brander, 1766: 19, pl. 1, fig. 29a.

Seraphs convolutus Wood, 1829: 7, pl. 1, fig. 29a. Non Terebellum convolutum Lamarck, 1802.

Terebellum sopitum - d'Orbigny 1850: 352, no. 263 partim. - Newton 1894: 98.

Terebellum (Seraphs) sopitus - Cossmann 1889: 96, 97.

Terebellum (Seraphs) sopitum - Cossmann 1904: 46.

Seraphs sopitus - Jung 1974: 16-21 partim, pl. 1, figs 1-3.

Type LOCALiTy. - Hordwell (England), Bartonian (Middle Eocene).

TYPE MATERIAL. - Lectotype (BMNH GG21010) designated by Jung (1974).

Other material examined. - See Appendix 1.

\section{DESCRIPTION}

\section{Shell}

Shell up to $40 \mathrm{~mm}$ in height and $14 \mathrm{~mm}$ in diameter, inflated with short and blunt apex (Fig. 6F, G). Aperture long and narrow. Callus of the inner lip thin and rarely preserved, except on the largest shell. Columella mainly straight but bent back, near the base. Outer lip very thin, not thickened and sinuous for the whole height in labral view 


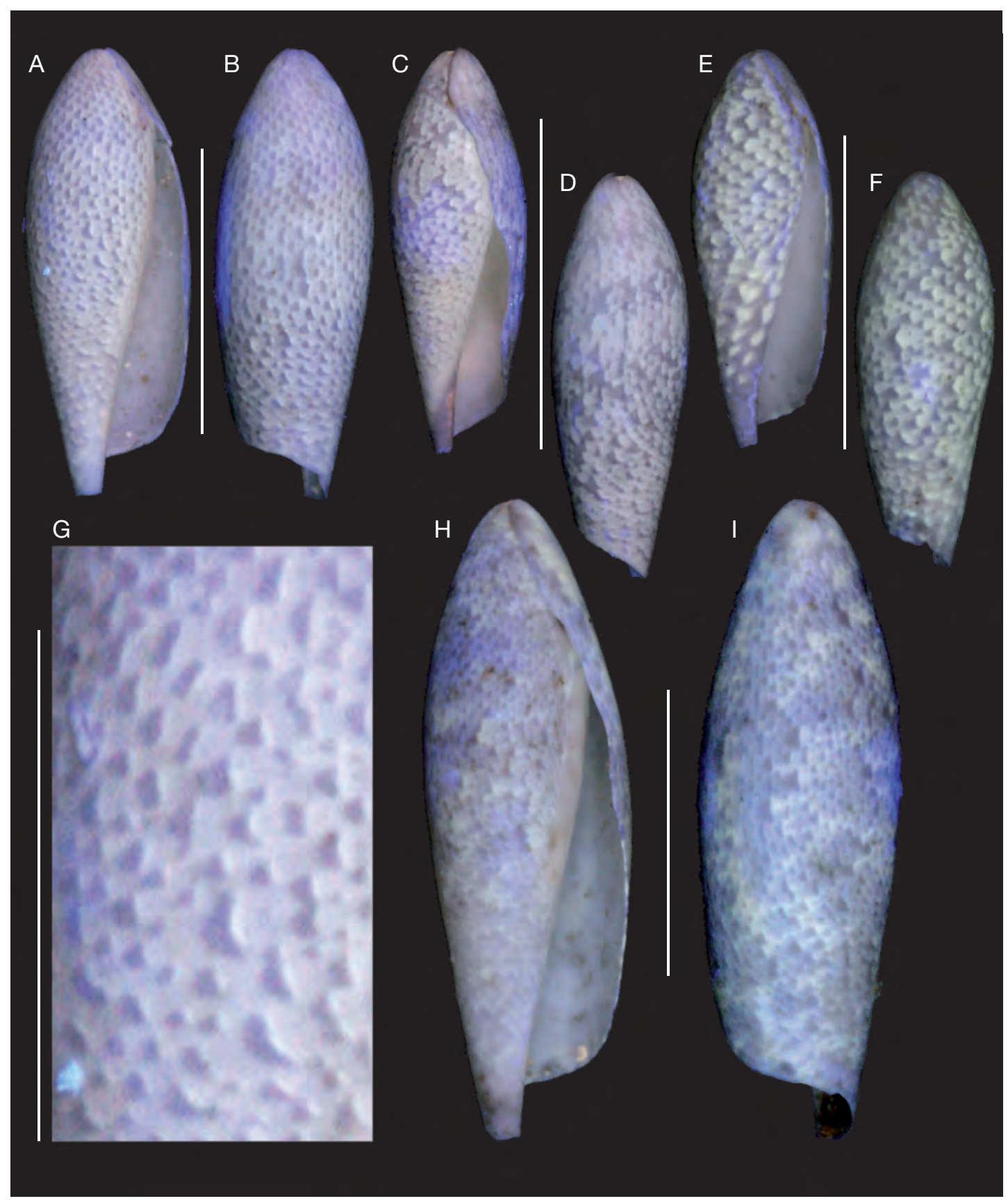

FIG. 7. - Seraphs volutatus (Solander in Brander, 1766) under UV light: A, B, G, MNHN A28873, Grignon, Yvelines, France, Lutetian; A, ventral view; B, dorsal view; G, detailed view of the dots; C, D, MNHN A28876, Grignon, Lutetian; C, ventral view; D, dorsal view; E, F, MNHN A28875 (Valenciennes coll.), Fontenay-en-Vexin, Eure, France, Lutetian; E, ventral view; F, dorsal view; H, I, MNHN A28874, Grignon, Lutetian; H, ventral view; I, dorsal view. Scale bars: A-F, H, I, 10 mm; G, 5 mm. Photographs by C. Lemzaouda (MNHN). 


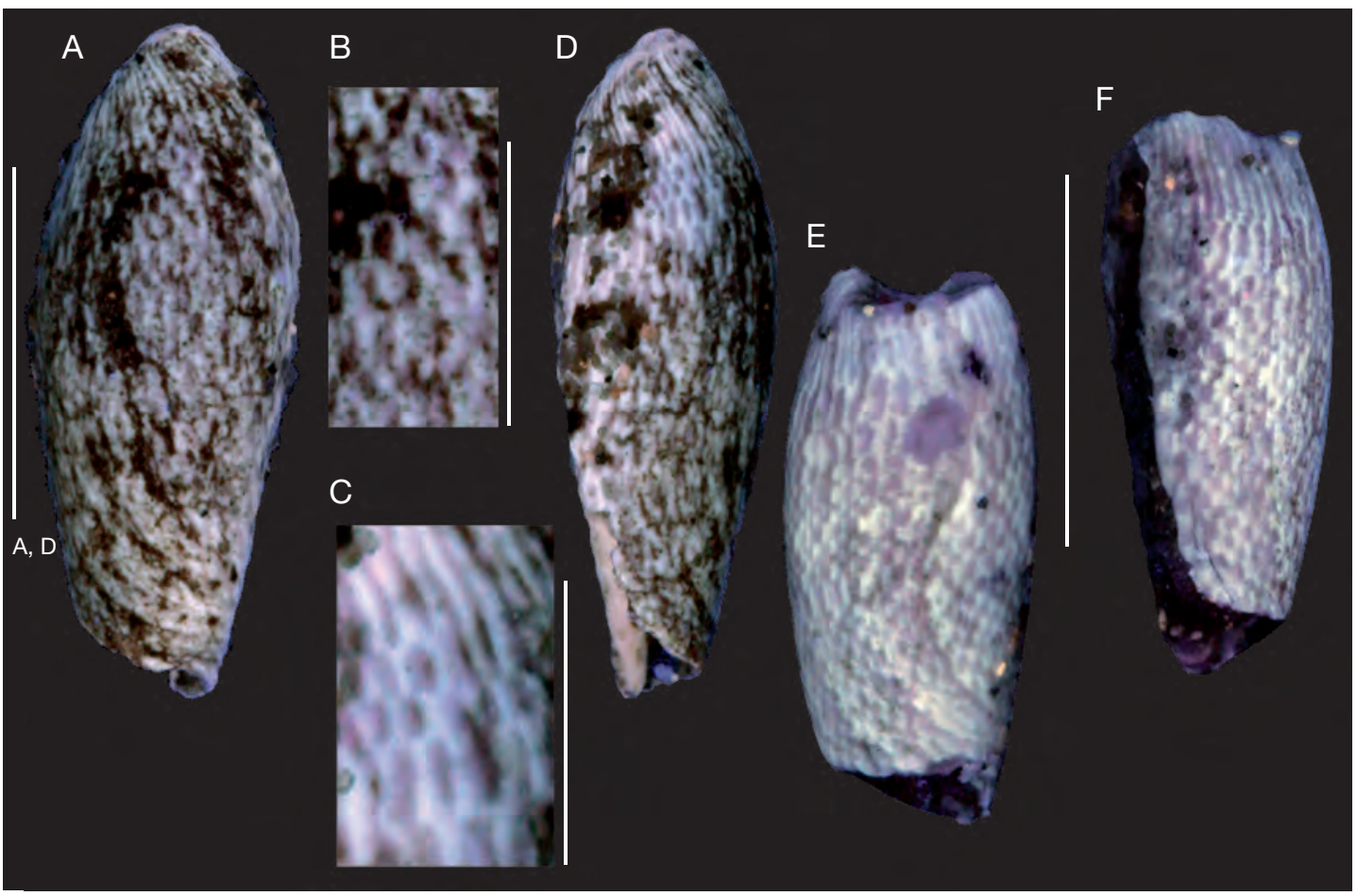

FIG. 8. - Oldest known specimens of Seraphs volutatus (Solander in Brander, 1766) under UV light: A-D, MNHN A30419, Sapicourt, Marne, France, Ypresian (Cuisian); A, dorsal view; B, C, detailed view of the dots; D, labral view; E, F, MNHN A30420, Sapicourt, Ypresian (Cuisian); E, dorsal view; F, labral view. Scale bars: A, D, E, F, 5 mm; B, C, 2 mm. Photographs by C. Lemzaouda (MNHN).

(Fig. 6G). Siphonal notch moderately deep on the dorsal side of the shell. No sculpture on the surface of the shell.

\section{Colour pattern}

The colour pattern consists of numerous small and irregular dots on a lighter background (Fig. 9). These dots show two levels of residual pigmentation (Fig. 9C, D, H, J, K): triangular spots, darker than the background, with the apex orientated towards the outer lip and diffuse, fluorescent spots lighter than the background and orientated towards the inner lip. These white fluorescent spots, adjacent to the base of the triangles, are variable in shape. They can be narrower than the dark triangles (Fig. 9C, D, J, K) or bigger and ovoid to almost circular (Fig. 9H). These two components form the dots. The dots are of various sizes. They are more distorted and axially elongated on the shell extremities (Fig. 9A, C).
When they coalesce, these dots form sinuous axial nearly collabral rows (Fig. 9A, E, F).

\section{Seraphs olivaceus (Cossmann, 1889)}

(Figs 6H-J; 10)

Terebellum (Seraphs) olivaceum Cossmann, 1889: 97, 98, pl. 3, figs 1, 2.

Terebellum (Seraphs) olivaceus - Cossmann 1904: 46. Cossmann \& Pissarro 1911: pl. 31, fig. 158-4.

Seraphs olivaceus - Jung 1974: 21, pl. 5, fig. 5-11, textfig. 15. - Le Renard 1992: 6. — Le Renard \& Pacaud 1995: 112. — Pacaud \& Le Renard 1995: 162.

Type LOCAlity. - Chaussy (Val d'Oise, France), Lutetian (Middle Eocene).

TYPE MATERIAL. - The illustrated syntype of Cossmann (1889) has been selected unambiguously by Jung (1974: 


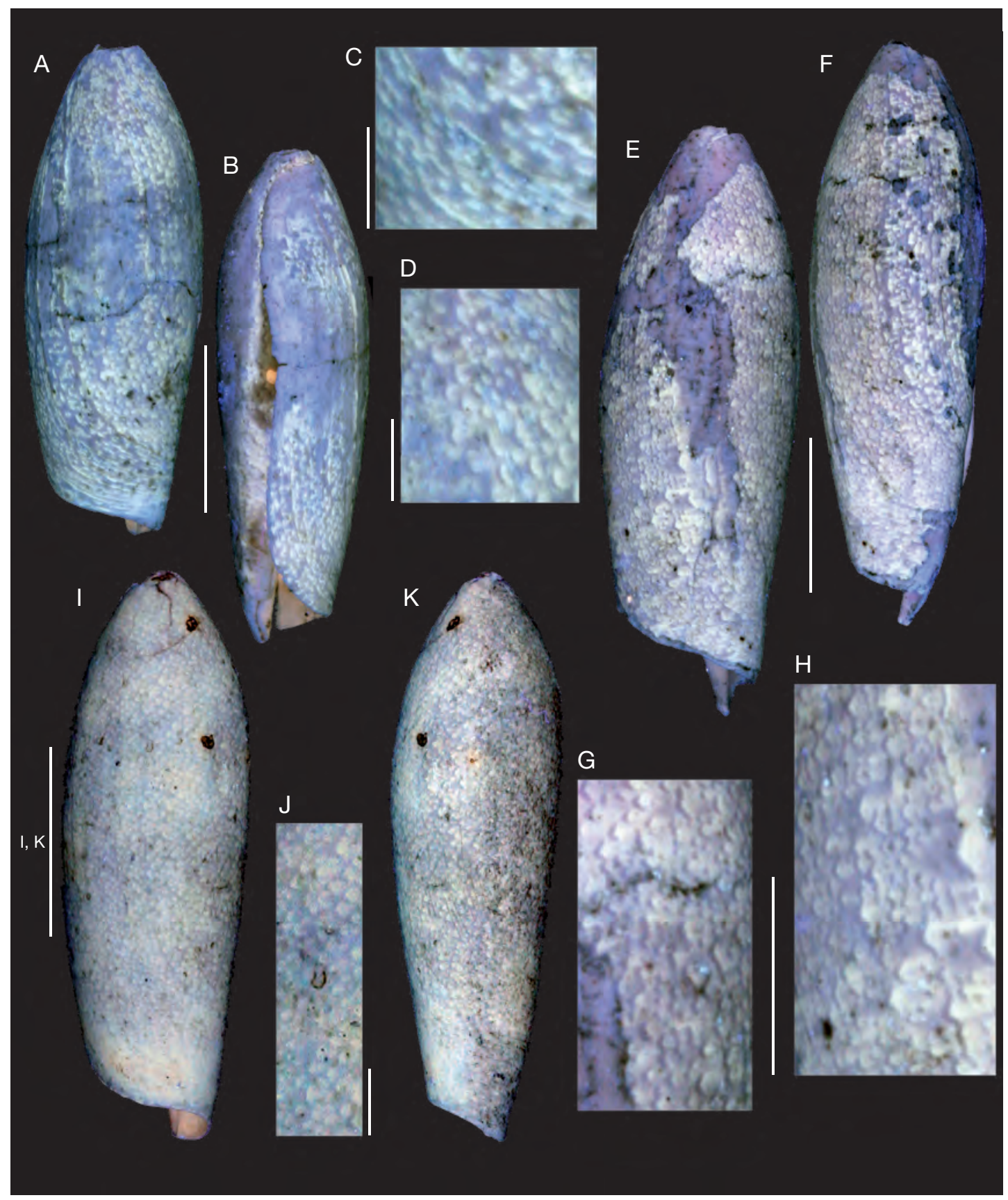

FIG. 9. - Seraphs sopitus (Solander in Brander, 1766) under UV light: A-D, MNHN A28884, Saint-Witz (Le Guépelle), Val d'Oise, France, Bartonian; A, dorsal view; B, labral view; C, D, detailed views of the dots; E-H, MNHN A27526, Saint-Witz (Le Guépelle), Bartonian; E, dorsal view; F, abapertural view; G, H, detailed views of the dots; I-K, MNHN A28778, Le Limon, Seine-et-Marne, France, Bartonian; I, dorsal view; J, detailed view of the dots; K, abapertural view. Scale bars: A, B, E, F, I, K, 10 mm; C, D, J, 2 mm; G, H, 5 mm. Photographs by C. Lemzaouda and P. Loubry (MNHN). 
21) as lectotype, using wrongly the term holotype: "Cossmann's figure [...]. This specimen is the holotype". According to article 74.5 of the ICZN (1999), this mention, made before 2000, constitutes a valid lectotype designation. Unfortunately, the type material of this species has not been found in the Bourdot collection, deposited at University of Lyon 1 (UCBL). A neotype designation is needed to clarify the taxonomic status of this species. A neotype from the type locality (MNHN A28885, leg. Pacaud, Fig. 10F-H) is accordingly chosen here. This initiative is in conformity with the rules specified by the ICZN (1999: art. 75), as regards the designation of a neotype.

Other material examined. — See Appendix 1.

\section{DESCRIPTION}

Shell

Shell up to $28 \mathrm{~mm}$ in height and $7 \mathrm{~mm}$ in diameter, moderately slender with elongated and pointed apex (Fig. 6H). Aperture long and narrow. Callus of the inner lip very thin, inconspicuous and rarely preserved. Straight columella near the base. Outer lip not thickened, reaching the apex and sinuous for the whole height in labral view, i.e. outer lip prosocyrt on the anterior part and opisthocyrt on the posterior part of the shell (Fig. 6J). Siphonal notch moderately deep on the dorsal side of the shell. No sculpture on the surface of the shell.

\section{Colour pattern}

The shells show small and irregular dots on a lighter background. These dots are composed of two levels of residual pigmentation (Fig. 10E, H). The first one consists of triangular spots, darker than the background. These small triangles are pointed towards the growing edge. The second one consists of white fluorescent fuzzy-bordered spots directed towards the inner lip. They are adjacent to the base of the dark triangles. White fluorescent spots are generally narrower than the dark spots (Fig. 10E, H). These two components form the dots. These dots, variable in size and sometimes coalescent (Fig. 10H), form sinuous axial nearly collabral rows (Fig. 10C, D, F, G). The space between these rows is narrow on the apex and broader on the median and basal parts of the shell.

\section{VARIABILITY OF THE COLOUR PATTERN}

The background is generally uniform and can bear large and diffuse darker areas (Fig. 10F-H). The density of the dots varies. When the density is high the axial rows are clearly defined, whereas they are less clearly or not defined when it decreases.

COMPARISONS OF THE THREE SPECIES OF SERAPHS:

$S$. VOLUTATUS, S. SOPITUS AND S. OLIVACEUS Shell

Among the representatives of Seraphs, the adult shell shape of S. volutatus, $S$. sopitus and S. olivaceus is very similar (Fig. 6). Moreover, these shells share a lack of sculpture. Seraphs volutatus generally has a straight columella, while it is bent in the two other species. Jung (1974) regarded Bulla volutata as a synonym of Bulla sopitus. However, according to Le Renard (1992), S. sopitus differs from S. volutatus by its short and blunt apex. For Jung (1974), S. olivaceus is distinguished from $S$. volutatus (= S. volutatus + S. sopitus sensu Jung [1974]) by an elongated and acute apical part (Fig. 6H). According to Jung (1974), S. volutatus shows a gradual change in the shell shape during ontogeny, and we observed some very large specimens similar to $S$. olivaceus and some small specimens similar to $S$. sopitus.

\section{Residual colour pattern}

Dots on a light background are common to $S$. volutatus (Fig. 8), S. sopitus (Fig. 9) and S. olivaceus (Fig. 10). These species show the same type of dots with two levels of residual pigmentation: 1) dark triangular spots orientated towards the growing edge; and 2) white fluorescent spots towards the inner lip. Furthermore, they have sinuous rows, almost parallel to the line of growth. In the studied material (22 ex.) of S. olivaceus, the dots are always small and less numerous than in the two other species.

\section{Discussion}

After study of 15 specimens of $S$. sopitus, 22 of S. olivaceus, 562 of $S$. volutatus, the colour patterns of each species appear variable, but very similar and no distinction can be made. According to Jung (1974) and Le Renard (1992), the main differences result from shell characters (the morphology of the apex and the columella). However, these differential characters, which vary during ontogeny and even in adulthood, were not defined considering variability. In conclusion, our personal opinion is that, 


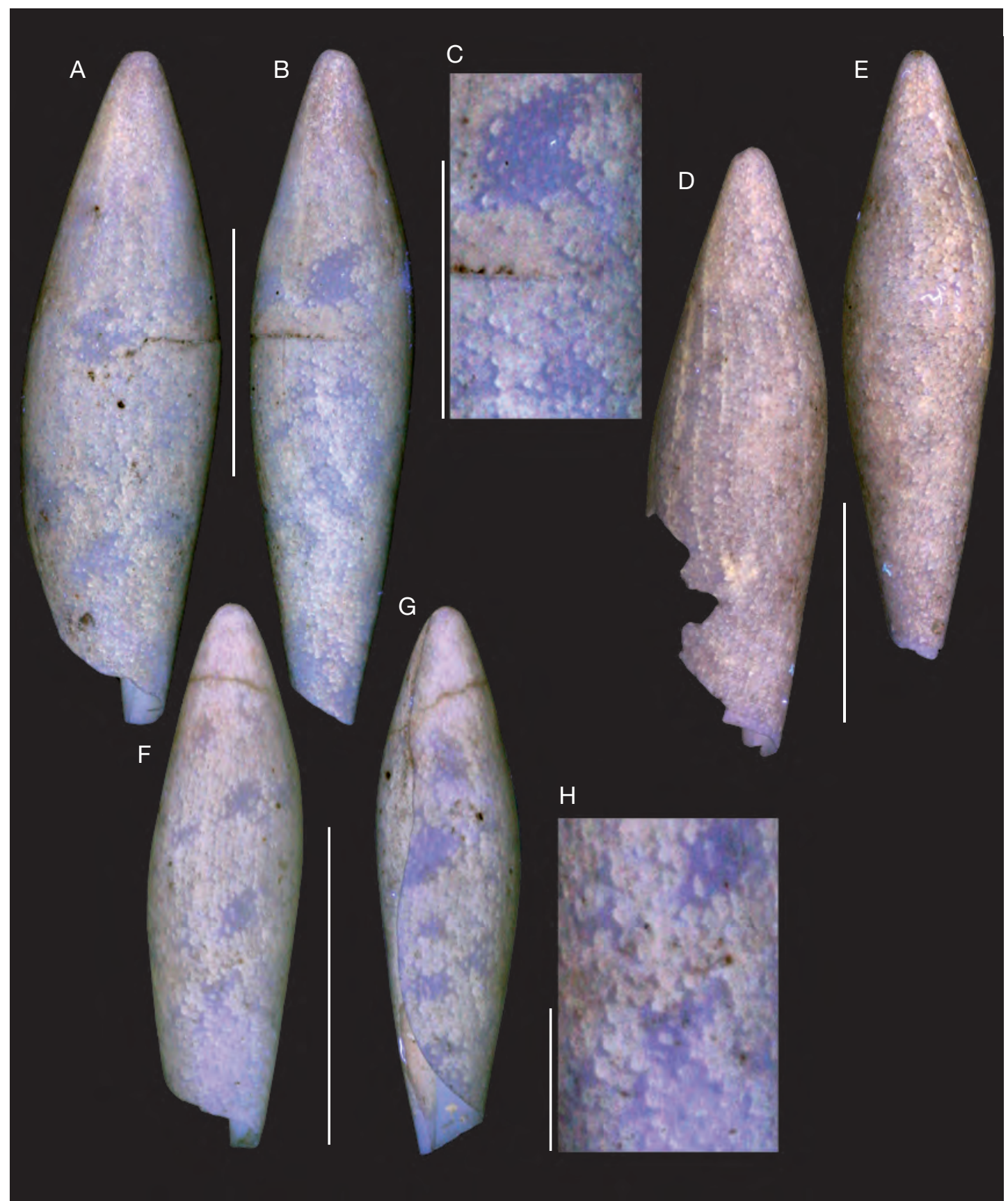

FIG. 10. - Seraphs olivaceus (Cossmann, 1889) under UV light: A-C, MNHN A28560 (leg. Pacaud), Chaussy (Les Garennes), Val d'Oise, France, Lutetian; A, dorsal view; B, abapertural view; C, detailed view of the dots; D, E, MNHN A29057 (Houdas coll.), Chaussy (Les Garennes), Lutetian; D, dorsal view; E, abapertural view; F-H, neotype, MNHN A28885 (leg. Pacaud), Chaussy (Les Garennes), Lutetian; F, dorsal view; G, labral view; H, detailed view of the dots. Scale bars: A, B, D-G, 10 mm; C, 5 mm; H, 2 mm. Photographs by C. Lemzaouda (MNHN). 
following the colour patterns, the discrimination of these three species is not justified. In order to know if it is necessary to continue to distinguish them, it would be rewarding to study the shell using modern morphometric methods.

\section{Seraphs sp. 1 \\ (Figs 11A-C; 12A-C)}

Seraphs sp. - Merle et al. 2008: 200, pl. 25, fig. 3.

Material EXAMINeD. - Lutetian, Chaussy (Les Garennes), Val d'Oise, 1 ex. (MNHN A25011, Faullummel coll.).

\section{DESCRIPTION}

Shell

Shell $13 \mathrm{~mm}$ in height and $4 \mathrm{~mm}$ in diameter, slightly inflated with short and blunt apex. Aperture long and narrow. Callus of the inner lip not preserved. Straight columella near the base. Outer lip very thin, not thickened and extending to the apex (Fig. 11A, B). Siphonal notch moderately deep on the dorsal side of the shell. No sculpture on the surface of the shell.

\section{Colour pattern}

The residual pattern is only composed of two levels of residual pigmentation: fluorescent axial stripes on a darker background. The stripes, sinuous overall, include some zigzags on short segments (Fig. 12AC). They are rarely continuous on the whole height of the shell. Their width is variable.

\section{COMPARISONS}

The shell shape is indistinguishable from that of young $S$. volutatus and they share the lack of sculpture. However, the residual pattern of Seraphs sp. 1 is very different from that of all other Seraphs in showing axial sinuous stripes. Moreover, it is the only pattern showing light elements on a darker background.

\section{DisCUSSION}

Although the residual colour pattern of Seraphs sp. 1 is clearly distinct (no intermediate pattern) from that of $S$. volutatus and even from that of the other Seraphs, we believe that it is preferable to avoid the description of a new species, because of the strong intrageneric variability and the occurence of only one specimen having this pattern.

Seraphs sp. 2

(Figs 11D, E; 12D-F)

Material eXAmined. - Lutetian, Fresville (Coteau de Vauville), Manche, 2 ex. (MNHN A28577, de Morgan coll.).

\section{DESCRIPTION}

Shell

Shell $18 \mathrm{~mm}$ in height and $6 \mathrm{~mm}$ in diameter, slightly inflated with short and blunt apex. Aperture long and narrow. Callus of the inner lip not preserved. Straight columella near the base. Outer lip extending to the apex but broken in labral view (Fig. 11D). Siphonal notch not observable (Fig. 10E). No sculpture on the surface of the shell.

\section{Colour pattern}

On the best preserved specimen, the residual pattern is only composed of two levels of residual pigmentation: dark spiral stripes on a lighter background. The stripes are broad and have marked borders (Fig. 12D-F). They are continuous and each stripe has the same width on the whole of the last whorl. The width of the different stripes is variable. On the less well-preserved specimen, a dark spiral stripe is present with dots, like in $S$. volutatus.

\section{COMPARISONS}

The shell shape of Seraphs sp. 2 is similar to that of young $S$. volutatus (Fig. 6A-C) and both species lack sculpture. Under UV light, the best preserved specimen is very different from the other Seraphs in showing thick and dark spiral stripes. The less well-preserved specimen is slightly similar, but bears dots as in $S$. volutatus.

\section{DISCUSSION}

If the best preserved specimen bears this peculiar pattern, the less well-preserved specimen suggests continuity between this pattern and that of $S$. volutatus, because of the occurrence of dots. Thus, as for Seraphs sp. 1, we prefer to avoid describing a new species, based on a small number of specimens. 


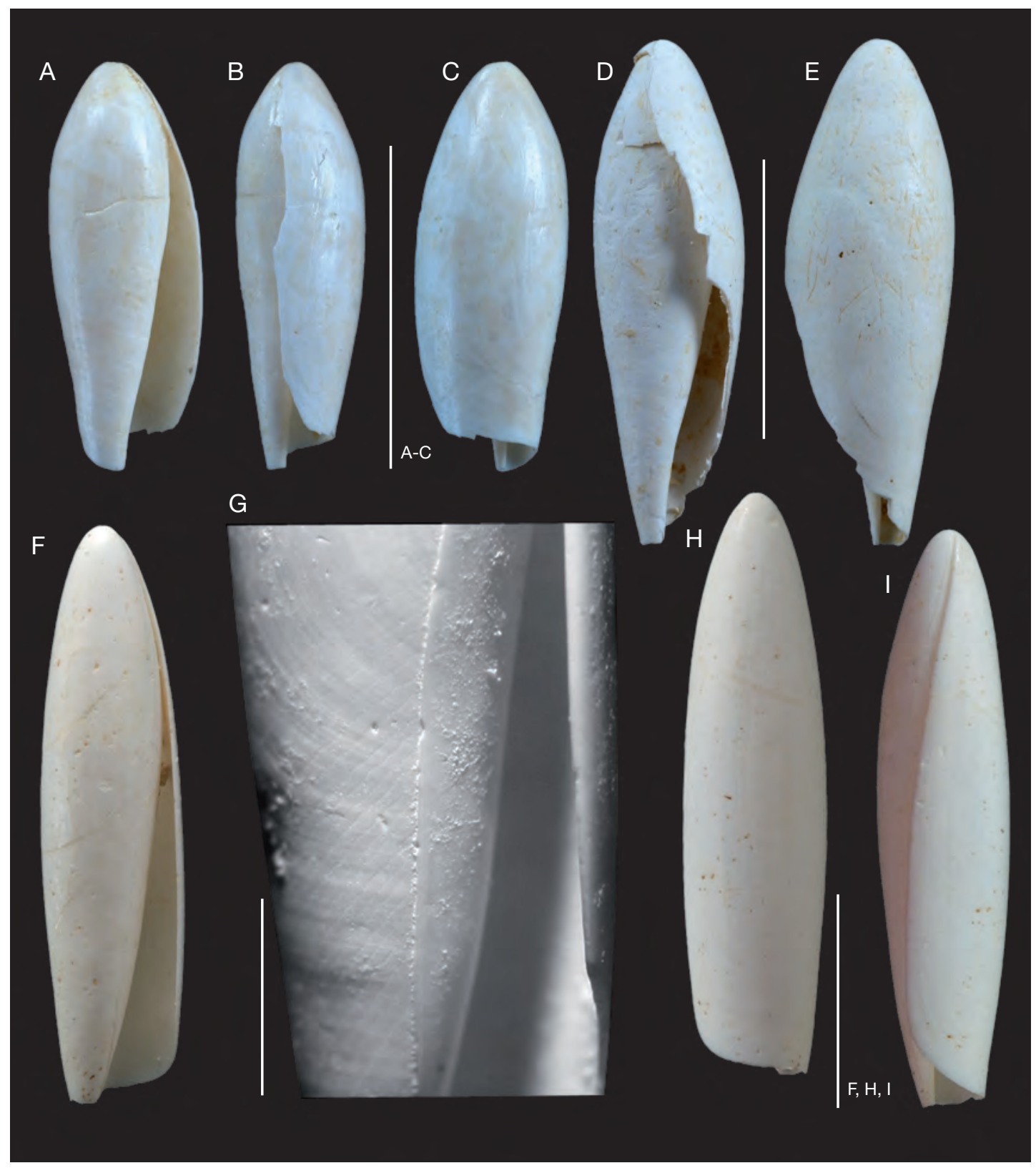

FIG. 11. - Seraphs Montfort, 1810 shells in normal light: A-C, Seraphs sp. 1, MNHN A25011 (Faullummel coll.), Chaussy (Les Garennes), Val d'Oise, France, Lutetian; A, ventral view; B, labral view; C, dorsal view; D, E, Seraphs sp. 2, MNHN A28887 (de Morgan coll.), Fresville (Coteau de Vauville), Manche, France, Lutetian; D, labral view; E, dorsal view; F-I, S. leukoleptus Jung, 1974; F, H, I, neotype, MNHN A28781 (Ledon leg.), Chaussy (Les Garennes), Lutetian; F, ventral view; H, dorsal view; I, labral view; G, MNHN A28968 (Houdas coll.), Chaussy, Lutetian, detailed view of the oblique grooves. Scale bars: A-F, H, I, 10 mm; G, 5 mm. Photographs by C. Lemzaouda (MNHN). 


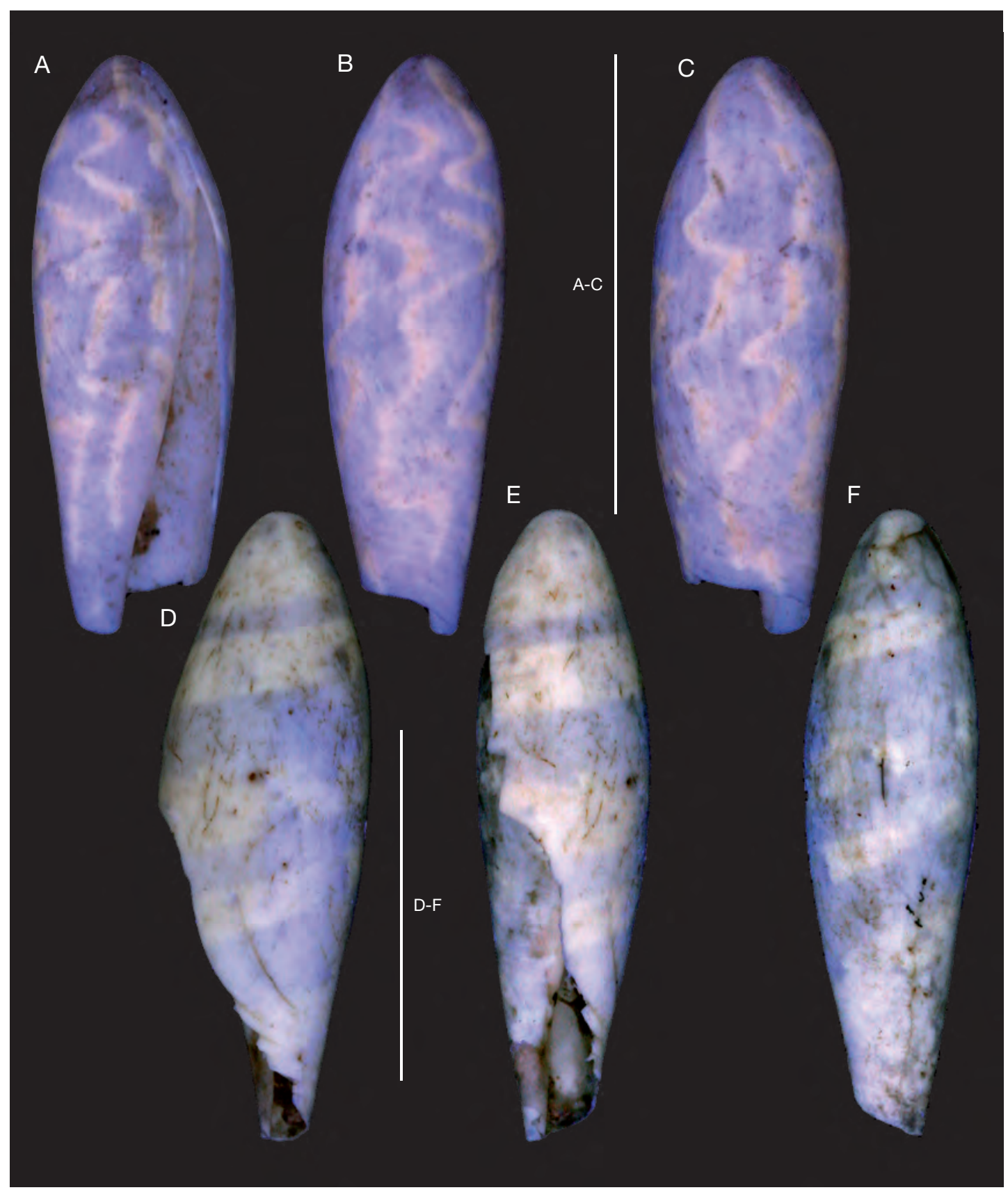

FIG. 12. - Seraphs Montfort, 1810 shells under UV light: A-C, Seraphs sp. 1, MNHN A25011 (Faullummel coll.), Chaussy (Les Garennes), Val d'Oise, France, Lutetian; A, ventral view; B, abapertural view; C, dorsal view; D-F, Seraphs sp. 2, MNHN A28887 (de Morgan coll.), Fresville (Coteau de Vauville), Manche, France, Lutetian; D, ventral view; E, labral view; F, abapertural view. Scale bars: $10 \mathrm{~mm}$. Photographs by C. Lemzaouda (MNHN). 


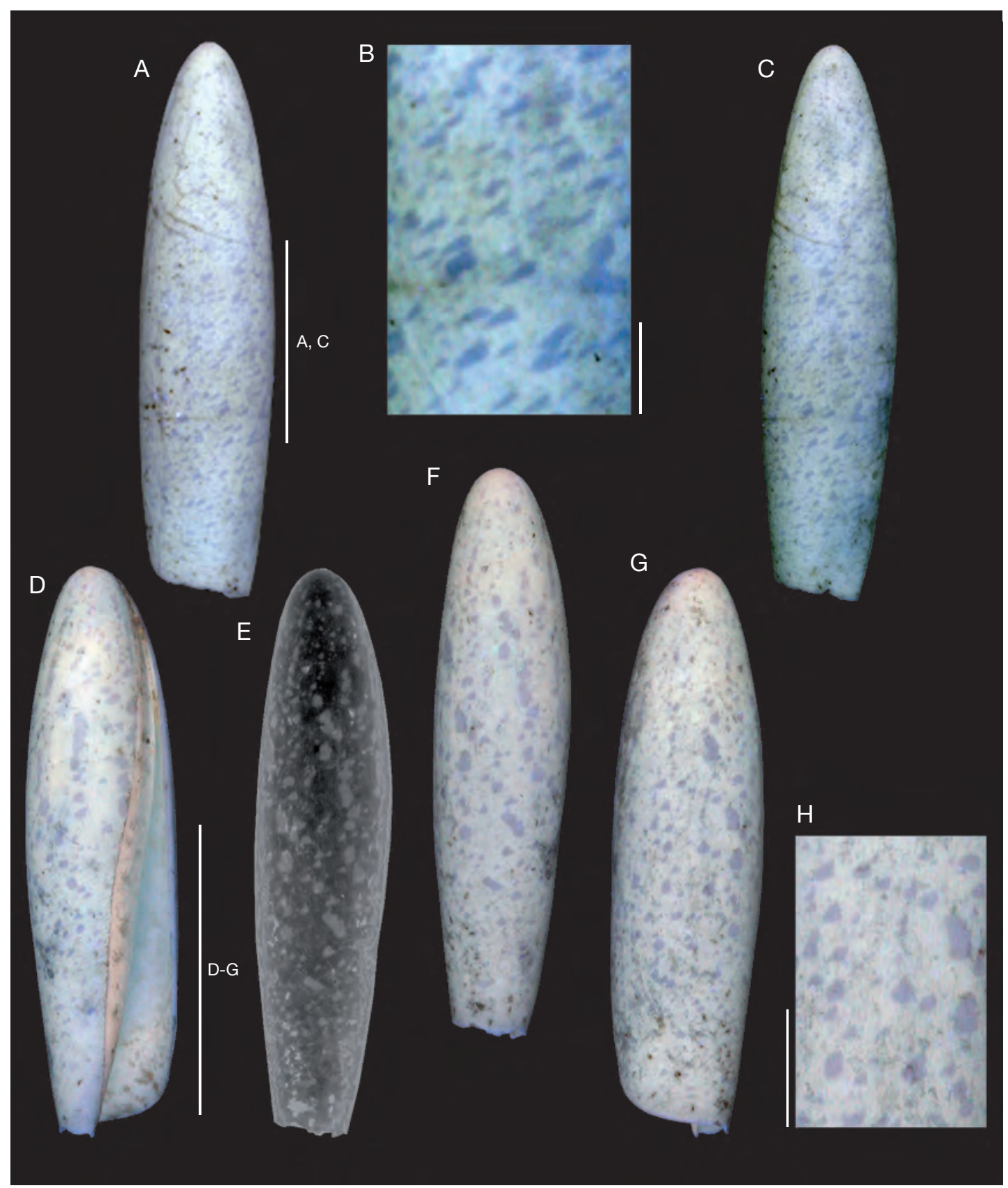

FIG. 13. - Seraphs leukoleptus Jung, 1974, under UV light: A-C, neotype, MNHN A28781 (Ledon leg.), Chaussy (Les Garennes), Val d'Oise, France, Lutetian; A, dorsal view; B, detailed view of the dots; C, abapertural view; D-H, MNHN A28968 (Houdas coll.), Chaussy (Les Garennes), Lutetian; D, ventral view; E, F, abapertural views (E negative view); G, dorsal view; H, detailed view of the dots. Scale bars: A, C-G, $10 \mathrm{~mm}$; B, H, 2 mm. Photographs by C. Lemzaouda and P. Loubry (MNHN). 


\section{Seraphs leukoleptus Jung, 1974}

(Figs 11F-I; 13)

Seraphs leukoleptus Jung, 1974: 23, 24, pl. 6, figs 1-3, text-fig. 17.

Terebellum (Seraphs) fusiformopse - Cossmann 1889: 97, pl. 3, figs 3, 4; 1904: 46 partim. - Cossmann \& Pissarro 1911: pl. 31, fig. 158-3. Non Terebellum fusiformopse de Gregorio, 1880.

Seraphs leukoleptus - Le Renard 1992: 6. - Le Renard \& Pacaud 1995: 112. — Pacaud \& Le Renard 1995: 162.

Type locality. - Chaussy, Les Garennes (Val d'Oise, France), Lutetian (Middle Eocene).

TyPe MATERIAL. - Holotype (Deshayes coll.); 1 paratype (Deshayes coll., Les Garennes, Chaussy). Unfortunately, the type material of this species has not been found in the Deshayes collection, deposited at the UCBL. A neotype designation is needed to clarify the taxonomic status of this species. A neotype from the type locality (MNHN A28781, Ledon leg.; Figs 11F, H, I; 13A-D) is thus chosen here. This initiative conforms to the rules specified by the ICZN (1999: art. 75), as regards the designation of a neotype.

Other material examined. - See Appendix 1.

\section{DESCRIPTION}

Shell

Shell up to $36 \mathrm{~mm}$ in height and $8 \mathrm{~mm}$ in diameter, very slender and elongated, with straight and almost parallel sides (Fig. 11F, H). Aperture long and narrow. Callus of the inner lip very thin, but well delineated, continuing adapically on the spire and forming a narrow band parallel to the outer lip. Columella slightly bent backwards near the base. Outer lip thickened, almost straight in labral view, opisthocline and extending to the apex (Fig. 11I). Shallow siphonal notch on the dorsal side of the shell (Fig. 11H). Few oblique faint grooves near the base (Fig. 11G).

\section{Colour pattern}

The residual pattern is only composed of 2 levels of residual pigmentation: dark dots on a lighter background (Fig. 13). The dark dots are small and spirally elongated forming narrow triangles (Fig. 13B-C, I). These triangles, orientated towards the outer lip, are irregularly spread over the whole surface.

\section{COMPARISONS}

Seraphs leukoleptus is the only species having a shell with straight and almost parallel sides. Moreover, it is easily distinguished from the other species by a shallow siphonal notch. The pattern of S. leukoleptus is distinguishable from the other patterns by its dots. They do not form rows, as observed in $S$. volutatus and S. olivaceus. Moreover, these dots are composed of only one level of residual pigmentation, while the other species have dots composed of two levels of residual pigmentation.

\section{Seraphs subconvolutus (d'Orbigny, 1852)}

(Fig. 14)

Terebellum subconvolutum d'Orbigny, 1852: 9, no. 140.

Terebellum convolutum - Grateloup 1834: 314, no. 604; 1846: pl. 1 [42] fig. 1. Non Lamarck, 1802.

Terebellum fusiforme - Grateloup 1834: 315, no. 605; 1846: pl. 1 [42] figs 2, 3. Non Lamarck, 1802.

Terebellum subfusiformis d'Orbigny, 1852: 9, no. 141.

Terebellum (Seraphs) subconvolutum - Cossmann 1904: 46.

Terebellum (s.s.) subconvolutum - Magne 1940: 33.

Terebellum subconvolutum - Vergneau 1967: 203, 206. — Bosatta et al. 1973: 190.

Seraphs subconvolutus - Jung 1974: 26, 27, pl. 8, figs 1-10, text-fig. 18.

Type locality. - Gaas (Landes, France), Rupelian (Oligocene).

TYPE MATERIAL. - Seraphs subconvolutus: the illustrated syntype (UBT 65-2-120, Grateloup. coll.) of Grateloup (1834) has been selected unambiguously by Jung (1974 :26) as lectotype, using wrongly the term of holotype: "They therefore represent the holotypes of S. subconvolutus...". But in the original work of d'Orbigny (1852), no holotype was designated for the taxon. In accordance with article 74.6 of the ICZN (1999), Jung's stipulation constitutes a lectotype fixation.

Terebellum subfusiformis: the illustrated syntype (UBT 65-2-121, Grateloup coll.) of Grateloup (1834) has been selected unambiguously by Jung (1974: 26) as lectotype, using wrongly the term of holotype: "They therefore represent the holotypes of $S$. subconvolutus and S. subfusiformis respectively". But in the original work 


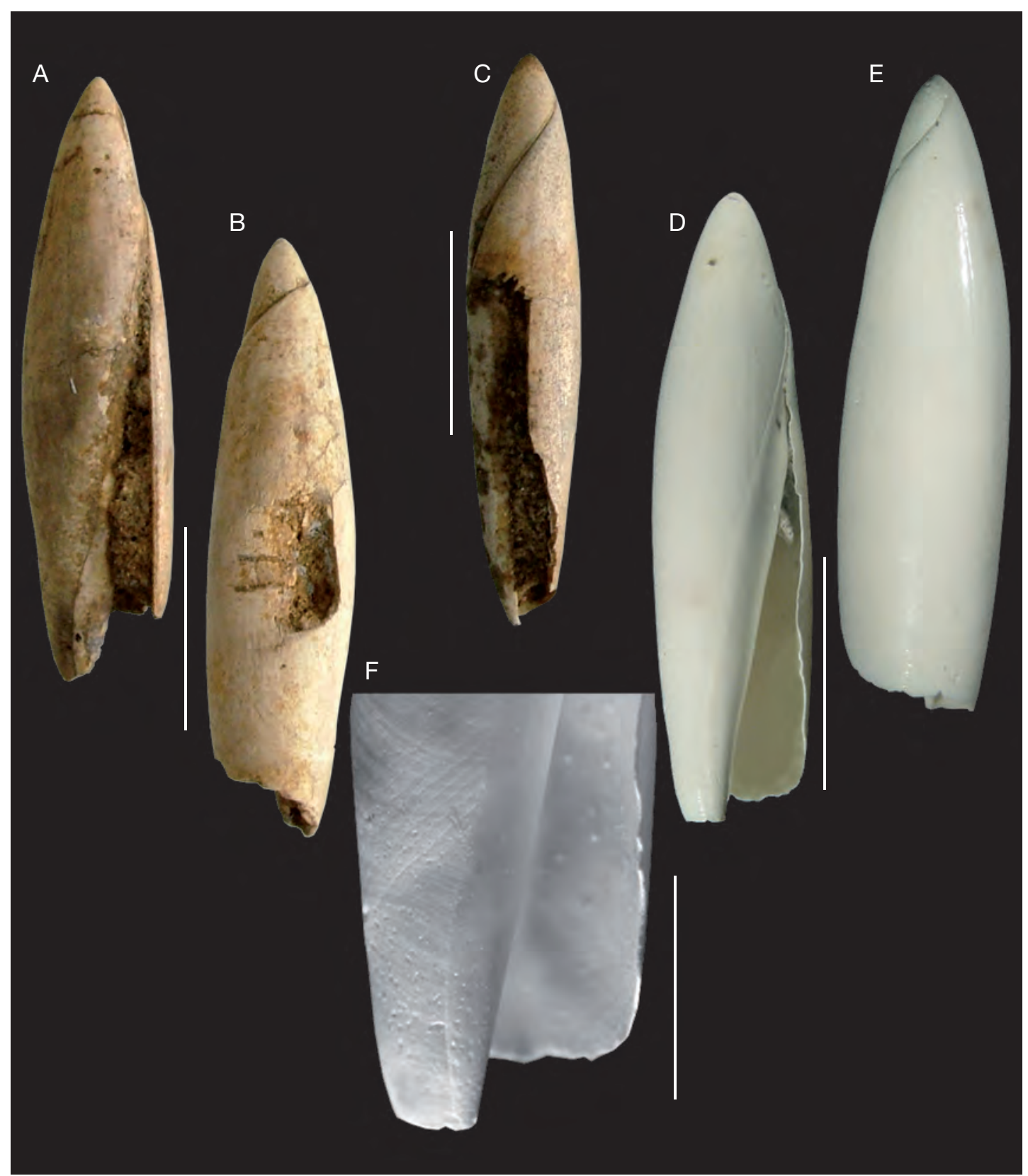

FIG. 14. - Seraphs Montfort, 1810 shells in normal light: A, B, holotype of S. subconvolutus (d'Orbigny, 1852), UBT 65-2-120 (Grateloup coll.), Gaas (Lesbarritz), Landes, France, Rupelian; A, ventral view; B, dorsal view; C, holotype of S. subfusiformis d'Orbigny, 1852 (labral view), UBT 65-2-121 (Grateloup coll.), Gaas (Lesbarritz), Rupelian; D-F, MNHN A28967 (Aucoin coll.), Gaas (Espibos), Rupelian; D, ventral view; E, dorsal view; F, detailed view of the oblique grooves. Scale bars: A-E, $10 \mathrm{~mm}$; F, $5 \mathrm{~mm}$. Photographs by C. Lemzaouda (MNHN). 
of d'Orbigny (1852), no holotype was designated for the taxon. In accordance with article 74.6 of the ICZN (1999), the Jung stipulation that the illustrated specimen is the holotype constitutes a lectotype fixation.

Other material eXAmined. - See Appendix 1.

\section{DESCRIPTION}

Shell

Shell up to $31 \mathrm{~mm}$ in height and $8 \mathrm{~mm}$ in diameter moderately slender with acute apical part. Aperture long and narrow. Callus of the inner lip thin, but well delineated, extending towards the apex and forming a narrow band parallel to the outer lip. Columella slightly bent backwards near the base of the shell. Outer lip slightly thickened and somewhat prosocyrt, in labral view, below the adapical end of the aperture (Jung 1974). Outer lip extending onto the posterior part of the shell, but bent towards the dorsal side (Fig. 14B, $\mathrm{C}, \mathrm{E})$ and "reaching the apex after about half a volution" (Jung 1974). Siphonal notch moderately deep. Surface sculpture of narrow oblique grooves observable on the ventral side near the base (Fig. 14F).

\section{Colour pattern}

No residual pattern is observed under UV light. Nevertheless, the studied specimens seem slightly corroded and we cannot preclude the possibility that the species originally had a colour pattern.

\section{COMPARISONS OF THE SHELL MORPHOLOGY}

Seraphs subconvolutus is similar to $S$. chilophorus and S. peterjungi n. sp. (Fig. 15) in sharing an abapical part of the columella slightly bent backwards, narrow oblique grooves on the ventral side near the base and a well delineated callus (Fig. 14D) of the inner lip forming adapically a narrow band parallel to the outer lip. However, this species is the only Seraphs having an opisthocline extension of the outer lip on the posterior part of the shell. The outer lip does not continue directly to the apex, but is bent towards the dorsal side reaching the apex after about half a volution (Fig. 14B, C, E). This feature of $S$. subconvolutus resembles that of members of Paraseraphs (Jung 1974), but the shell is involute as in other Seraphs.

\section{Seraphs chilophorus (Cossmann, 1889)}

(Figs 15A-I; 16; 17)

Terebellum (Seraphs) chilophorum Cossmann, 1889: 98, pl. 3, figs 5, 6;

Terebellum (Seraphs) chilophorum - Cossmann 1904: 45, pl. 2, fig. 6. - Cossmann \& Pissarro 1911: pl. 32, fig. 158-5. - Korobkov 1955: 260, pl. 57, fig. 3. Glibert 1963: p. 39.

Seraphs chilophorus - Jung 1974: 22, pl. 5, figs 12-21, text-fig. 15-16. — Dolin et al. 1980: 28. — Savazzi 1991: 324, fig. 13I, J. — Le Renard 1992: 6. — Le Renard \& Pacaud 1995: 112. — Pacaud \& Le Renard 1995: 162. Merle et al. 2008: 198, pl. 25, figs 1a, b, 2.

Type Locality. - Fontenay-en-Vexin, Bois du But (Eure, France), Lutetian (Middle Eocene).

TYPE MATERIAL. - The illustrated syntype (Bourdot coll., sample Bernay) of Cossmann (1889) has been selected unambiguously by Jung (1974: 22) as lectotype, using wrongly the term holotype: "Cossmann's original figure [...]. This specimen is the holotype". In accordance with article 74.5 of the ICZN (1999) this mention, made before 2000, constitutes a valid lectotype designation. Unfortunately, the type material of this species has not been found in the Bourdot collection, now deposited at UCBL. A neotype designation is needed to clarify the taxinomic status of this species. A neotype from the locality of Fontenay-en-Vexin (MNHN A25009, Fig. 16C-E) is accordingly chosen here. This initiative conforms to the rules specified by the ICZN (1999: art. 75), as regards the designation of a neotype.

Other material examined. - See Appendix 1.

\section{DESCRIPTION}

Shell

Shell up to $28 \mathrm{~mm}$ in height and $8 \mathrm{~mm}$ in diameter, moderately slender with acute apical part. Aperture long and narrow. Callus of the inner lip well developed and well delineated, continuing adapically on the spire and forming a narrow band parallel to the outer lip (Fig. 15C). Columella bent backwards near the base. Outer lip, slightly thickened and sinuous in labral view, near the adapical end of the aperture. Outer lip extending to the apex and continuing on the opposite side of the apex for a short distance (Fig. 15G, I). Jung called this apical part of the outer lip, the apical canal. Siphonal notch moderately deep on the dorsal side. Surface sculpture of narrow oblique grooves near the base (Fig. 15H). 


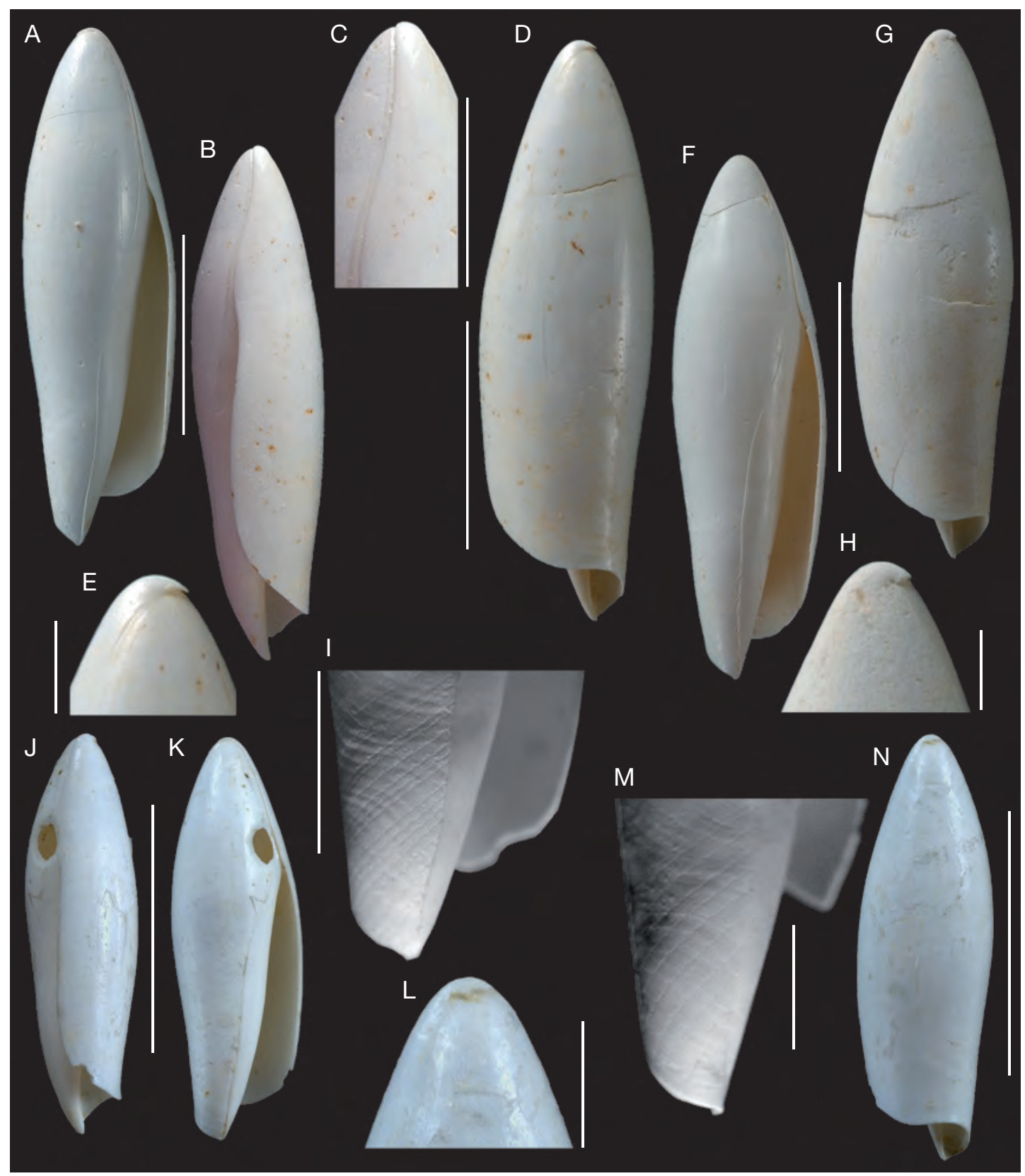

FIG. 15. - Seraphs Montfort, 1810 shells in normal light; A-I, S. chilophorus (Cossmann, 1889); A-E, MNHN A28779 (Ledon coll.), Chaussy (Les Garennes), Val d'Oise, France, Lutetian; A, ventral view; B, labral view; C, detailed view of the apical part; D, dorsal view; E, detailed view of the apical part; F-H, MNHN A28780 (Ledon coll.), Chaussy (Les Garennes), Lutetian; F, ventral view; G, dorsal view; H, detailed view of the apical part; I, MNHN A27783, detailed view the oblique grooves (leg. Pacaud), Saint-Lubin-de-la-Haye, Eure-et-Loir, France, Lutetian; J-N, S. peterjungi n. sp., holotype MNHN A28578 (Pacaud leg.), Chaussy (Les Garennes), Lutetian; $\mathbf{J}$, ventral view; K, labral view; L, detailed view of the apical part; $\mathbf{M}$, detailed view the oblique grooves; $\mathbf{N}$, dorsal view. Scale bars: A-B, D, F-G, J-K, N, 10 mm; C, I, 5 mm; E, H, L, M, 2 mm. Photographs by C. Lemzaouda (MNHN). 


\section{Colour pattern}

The colour pattern is composed of two different dark elements on a lighter background: thick rows of patches nearly perpendicular to the line of growth and tiny dots located between these rows.

The rows are composed of dark triangular patches (7-8). The apex of each of is orientated towards the outer lip. The patches are usually disconnected and separated by a small white fluorescent patch. This morphology is called a fishbone pattern (Fig. 16I, J) by Meinhardt (1998: fig. 4.10). The distance between the rows and their width are variable. Sometimes, several rows are adjacent to one another (Fig. 16F). The dots are small and more or less triangular (Fig. 16E). As for the patches, the apex is always directed towards the outer lip. Their size, distribution and shape are heterogenous and irregular. Above the most adapical row, the density and the size of dots are often greater as is the degree of coalescence (Fig. 16H).

\section{COMPARISONS OF THE SHELL MORPHOLOGY}

The morphologies of $S$. chilophorus and $S$. peterjungi n. sp (Fig. 15J-N) are very similar with their thickened callus of the inner lip and their narrow band on the adapical part of the shell. Moreover, they share an apical canal (Fig. 15G, I, L), lacking in the other Seraphs.

The shell of $S$. chilophorus is more slender than those of S. volutatus (Fig. 6A-E) and S. sopitus (Fig. 6F, G). This species is generally more slender than $S$. olivaceus, although both can have an acute apex. Also, S. chilophorus clearly differs from $S$. olivaceus, $S$. volutatus or $S$. sopitus by the morphology of its outer lip and its callus of the inner lip.

\section{VARIABILITY OF THE COLOUR PATTERN}

Among 163 specimens from various localities (11 from the Lutetian and 1 from the Bartonian), 160 (98.16\%) show a residual colour pattern under UV light (Table 1). Accordingly, these observations provide a good general survey of the intraspecific variability.

The residual pattern of $S$. chilophorus is quite variable (Fig. 17) and is often subject to significant distortion of the elements on the shell extremities, especially the apical one (Fig. 17C-F).

The huge variability is visible on every element of the residual pattern. The number of spiral rows varies from 0 to 6 . Several shells show partially or totally connected rows (Fig. 17B, D). The shape of the dark patches can show important variations from triangular (Fig. 17A, C) to completely distorted or shapeless (Fig. 17F, J). Although they are usually separated by a small fluorescent patch, they may be connected with each other (Fig. 17E). The density of dots fluctuates from low values (Fig. 17A, D-F) to very high ones (Fig. 17K). In this case, the dots form axial rows more or less coalescent (Fig. 17K$\mathrm{N})$. This coalescence sometimes increases until the dots disappear and only axial segments are observable (Fig. 17H, M, N). There are often some large triangular and coalescent patches near the edge of the outer lip. Finally, there are sometimes small axial segments between the dark patches of the rows (Fig. 17J).

In spite of this variability, we can distinguish three morphological types. The most abundant an representative type 1 is composed of spiral rows of dark triangles directed towards the outer lip and small dots between them (Fig. 17A-C, I). The type 2 shows some thin and tightened axial segments with, often, remnants of spiral rows of triangular patches (Fig. $17 \mathrm{H}, \mathrm{N}, \mathrm{O}$ ). The type 3 shows only large and more or less coalescent dark triangles (Fig. 17D, E). Several shells bear a morphology intermediate (Fig. 18) between types 1 and 2 (Fig. 17J-M), between types 1 and 3 (Fig. 17F), between types 2 and 3 (Fig. 17G). The relative abundance of these morphologies is given in Figure 18. Figure 17 illustrates this variability with a certain disparity, but the observation of numerous intermediate specimens suggest that it is impossible to separate one type from another, as different species.

\section{COMPARISONS OF THE COLOUR PATTERN}

Seraphs chilophorus (Fig. 16) bears dots, as S. volutatus, S. sopitus, S. olivaceus and S. leukoleptus (Figs 7-10). The pattern of $S$. chilophorus is, however, easily distinguishable as the dots are composed of only one residual colour and by the occurrence of broad spiral rows of dark patches. 


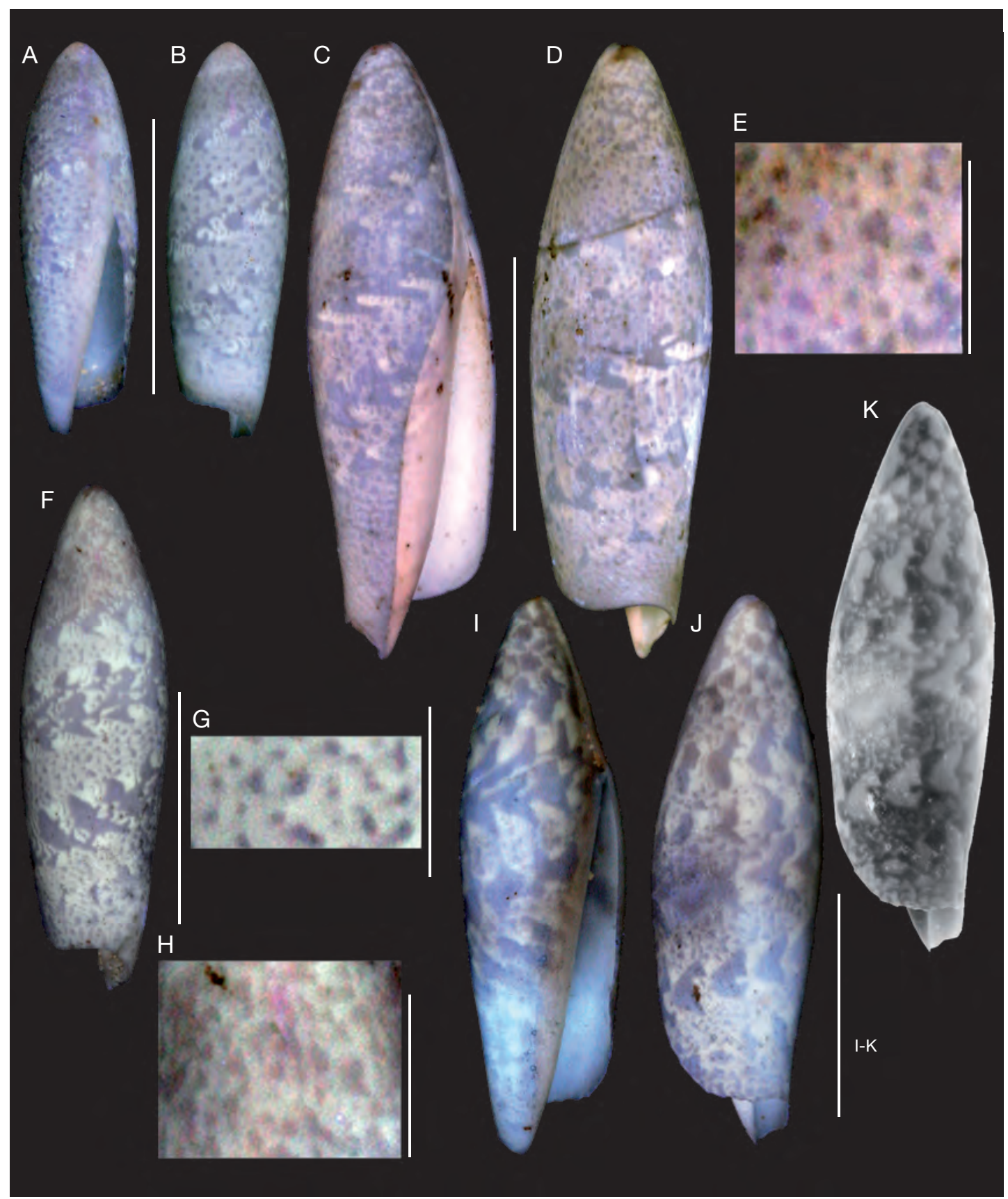

FIG. 16. - Seraphs chilophorus (Cossmann, 1889) under UV light: A, B, MNHN A28927 (Roissy coll.), Parnes, Oise, France, Lutetian; A, ventral view; B, dorsal view; C-E, neotype MNHN A25009, Fontenay-en-Vexin, Eure, France, Lutetian; C, ventral view; D, dorsal view; E, detailed view of the dots; F-H, MNHN A28924 (leg. Pacaud), Fercourt, Oise, France, Lutetian; F, dorsal view; G, H, detailed views of the dots; I-K, MNHN A28928 (leg. Pacaud), Parnes, Oise, France, Lutetian; I, ventral view; J, K, dorsal views (K negative view). Scale bars: A-D, F, I-K, 10 mm; E, G, H, 2 mm. Photographs by C. Lemzaouda (MNHN). 


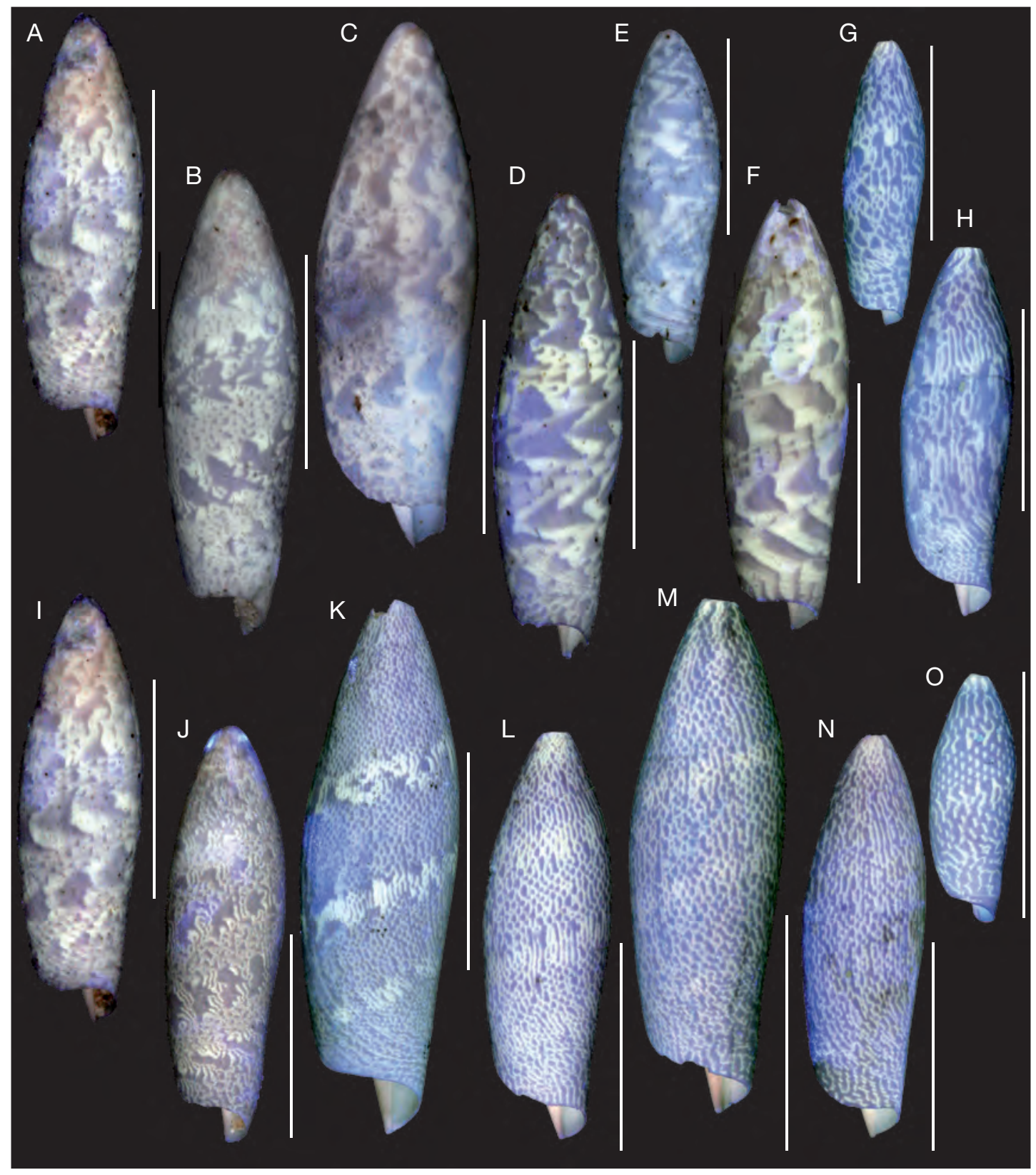

FIG. 17. - Variability of Seraphs chilophorus (Cossmann, 1889) in dorsal view and under UV light: A, I, MNHN A28926 (leg. Pacaud), Fercourt, Oise, France, Lutetian; B, MNHN A28924 (leg. Pacaud), Fercourt, Lutetian; C, MNHN A28928 (leg. Pacaud), Parnes, Oise, France, Lutetian; D, MNHN A28922 (leg. Pacaud), Fercourt, Lutetian; E, MNHN A28921 (1965-11 coll.), Saulxmarchais, Yvelines, France, Lutetian; F, MNHN A28923 (leg. Pacaud), Fercourt, Lutetian; G, MNHN A28919 (leg. Pacaud), Parnes, Lutetian; H, MNHN A28891 (leg. Pacaud), Parnes, Lutetian; J, MNHN A28925 (leg. Pacaud), Fercourt, Lutetian; K, MNHN A28888 (leg. Pacaud), Parnes, Lutetian; L, MNHN A28929 (leg. Pacaud), Parnes, Lutetian; M, MNHN A28889 (leg. Pacaud), Parnes, Lutetian; N, MNHN A28890 (leg. Pacaud), Parnes, Lutetian; O, MNHN A28920 (leg. Pacaud), Parnes, Lutetian; A-C, I, Type 1; H, N, O, Type 2; D, E, Type 3; J-M, intermediaries 1-2; F, intermediary 1-3; G, intermediary 2-3. Scale bars: $10 \mathrm{~mm}$. Photographs by C. Lemzaouda (MNHN). 
Seraphs peterjungi $\mathrm{n} . \mathrm{sp}$.

(Figs 15J-N; 19)

Type LOCALITY. — Chaussy, Les Garennes (Val d'Oise), France, Lutetian (Middle Eocene).

Type Material. - Holotype: MNHN A28578, leg. Pacaud.

Paratypes: Chaussy (Les Garennes), Val d'Oise, 2 ex., MNHN A27613 (1965-11 coll.); 1 ex., MNHN A28506 (Morlet coll.); 1 ex., MNHN A28931 (leg. Pacaud); 1 ex., MNHN A27273 (leg. Pacaud); 1 ex. MNHN A28537 (Faullummel coll.); 1 ex., MNHN A28538 (Faullummel coll.); 1 ex., MNHN A27550 (Schtrock coll.); 1 ex., MNHN A28550 (leg. Pacaud); 1 ex., MNHN A28559 (Ledon coll.);

Beynes, Yvelines, 1 ex., MNHN A28789;

Fercourt, Oise, 5 ex., MNHN A27634 (leg. Pacaud);

Grignon, Yvelines, 1 ex., MNHN A27632 (ex Galerie de Zoologie coll.); 1 ex., MNHN A28512 (leg. Caze);

1 ex., MNHN A28530 (Ballot coll.);

Parnes, Oise, 1 ex., MNHN A11186 (d'Orbigny coll.); 1 ex., MNHN A28511 (Roissy coll.);

Parnes (Grande Cronière), Oise, 1 ex., MNHN A28521 (leg. Pacaud);

Saulx-Marchaix, Yvelines, 1 ex., MNHN A28520 (196511 coll.).

Etymology. - Dedicated to Peter Jung for his work on the Seraphsidae.

\section{DESCRIPTION OF THE HOLOTYPE}

Shell $23 \mathrm{~mm}$ in height and $7 \mathrm{~mm}$ in diameter, slender with acute apical part. Aperture long and narrow. Callus of the inner lip well developed and delineated, continuing adapically on the spire and forming a narrow band parallel to the outer lip. Columella bent backwards near the base (Fig. 15K). Outer lip slightly thickened and, in labral view, sinuous near the adapical end of the aperture. Outer lip extending to the apex and continuing on the opposite side for a short distance (Fig. 15K, L, N). Siphonal notch moderately deep on the dorsal side of the shell. Surface sculpture of narrow oblique grooves near the base (Fig. 15M).

\section{COLOUR PATTERN DESCRIPTION}

The colour pattern shows two different and superimposed levels of residual pigmentation: a dark one and a white and fluorescent one. The background displays an intermediate colour between these two levels. The darker elements correspond to several

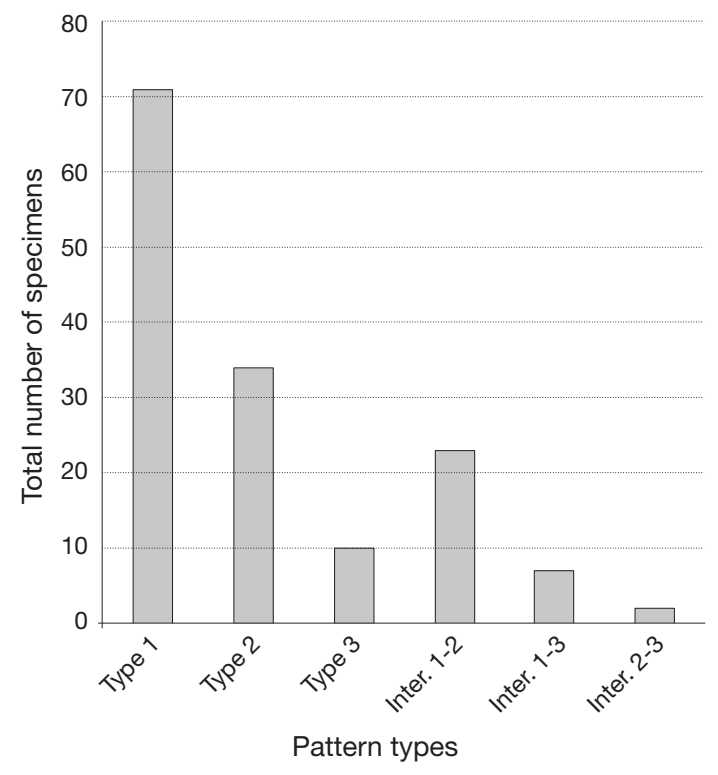

FIG. 18. - Distribution of the pattern types with their intermediaries (Inter.) in Seraphs chilophorus (Cossmann, 1889).

thick spiral rows of patches. The lighter fluorescent elements, overlaid on the darker, consist of narrow spiral lines. The morphology of the dark elements is similar to the pattern of $S$. chilophorus: several spiral rows of dark triangles of which the apex is directed towards the outer lip. Their width, depending on the size of the patches, is variable (Fig. 19A, B). In addition, some tiny and isolated triangles, orientated towards the outer lip, are visible between the rows (Fig. 19G, H). Their size, distribution and shape are heterogenous and irregular (Fig. 19G, H). On the apical part of the shell, the elements are more dense and coalescent, tending to be shapeless.

\section{VARIABILITY}

The variability is only observable on the darker elements of the residual pattern. The rows can be more or less distant, from widely spaced to contiguous (Fig. 19A, E, F). Dark patches can show considerable shape variation from triangular to completely distorted (Fig. 19E, F). They can be well separated or connected. The fluorescent elements, narrow spiral lines, do not show perceptible variation except in their number: between 16 and 20 . 
SHELL AND COLOUR PATTERN COMPARISONS

The shell of Seraphs peterjungi $\mathrm{n}$. sp. is indistinguishable from that of Seraphs chilophorus. Accordingly, for shell comparison with the other species, see S. chilophorus.

The dark underlying elements of $S$. peterjungi n. sp. resemble the colour pattern of $S$. chilophorus, but it appears to be less variable. Seraphs chilophorus never has fluorescent narrow lines.

\section{DisCUSSION}

The comparisons between $S$. peterjungi n. sp. and $S$. chilophorus are respectively based on 24 specimens and 163 specimens (Table 1). Using the shell shape, no distinction can be made between the two populations. Using the residual pattern, we can observe a strong similarity in the dark component, suggesting a close relationship. However, S. peterjungi n. sp. shows an additional element with some light and fluorescent spiral lines (Fig. 19), lacking in all examined S. chilophorus (Fig. 16) and suggesting a morphological discontinuity. Considering the number of specimens studied and the lack of intermediaries between the two colour patterns, we cannot regard both populations as a single species. In this case, the residual pattern does seem to be a unique discriminating criterion enabling the differentiation of fossil species.

\section{Genus Diameza Deshayes, 1865}

TYPE SPECIES. - Ovula media Deshayes \& Milne-Edwards, 1844 (= Ovula fragilis Defrance, 1825) by monotypy. Lutetian, Paris Basin.

\section{GENERIC DISCUSSION}

Jung (1974) considered Diameza and Miniseraphs Jung, 1974, as two subgenera of Seraphs. Nevertheless, S. (Diameza) fragilis (Defrance, 1825), S. (Miniseraphs) eratoides (Cossmann, 1889) and S. (Miniseraphs) isabella (Bernay in Deshayes, 1865) have very small and inflated shells with a large apical angle (Fig. 20) which are obviously different from those of Seraphs (s.s.) (Figs 6; 11; 15) which are larger, slender and more elongated. Thus, these species are, here, no longer considered to belong to the genus Seraphs and are placed together within Diameza, which is here raised to the generic level. The name Diameza, older than the name Miniseraphs, is selected for this genus including two subgenera: Diameza and Miniseraphs.

Under UV light, these three species show very similar patterns (Figs 21-23). They bear sinuous or wavy axial lines which are lacking in Seraphs (Figs 7-10; 12; 13; 16; 18), in Paraseraphs (Figs 26; 28; 30) and Terebellum (Figs 1;2). These observations strengthen the initial interpretation based on the shell morphology: Diameza (s.s.) fragilis, D. (Miniseraphs) eratoides and D. (Miniseraphs) isabella are closely related and very different from all other fossil and Recent species.

\section{Subgenus Diameza Deshayes, 1865}

\section{Diameza (s.s.) fragilis (Defrance, 1825)}

(Figs 20A-E; 21)

\section{Ovula fragilis Defrance, 1825: 132.}

Rostellaria macroptera Lamarck, 1803: 220, no. 1 partim (testa junior, incompleta), vélin 4, fig. 5a-c. - Palmer 1977: 15, vélin 4, fig. 5a-c.

Ovula intermedia Deshayes, 1835: 718, pl. 95, fig. 3437. Non Sowerby, 1830.

Ovula media Deshayes \& Milne-Edwards, 1844: 479, 480 (nomen novum pro Ovula intermedia Deshayes, 1835 non Sowerby, 1830). — Deshayes 1865: 572.

Ovula (Diameza) media - Fischer 1884: 665.

Diameza media - Cossmann 1889: 99, pl. 3, fig. 16. Cossmann \& Pissarro 1911: pl. 32, fig. 159-1.

Terebellum (Diameza) media - Cossmann 1904: 48, pl. 3, figs 9-12.

Terebellum (Diameza) medium - Wenz 1940: 939, fig. 2744. — Glibert 1963: 40.

Seraphs (Diameza) intermedius - Jung 1974: 30, pl. 9, figs 10-12, text-figs 19, 20. - Savazzi 1991: 324, fig. 13L. — Le Renard 1992: 6.

Seraphs (Diameza) fragilis - Le Renard \& Pacaud 1995: 112. — Pacaud \& Le Renard 1995: 162. — Le Renard 2001: 17, 18. 


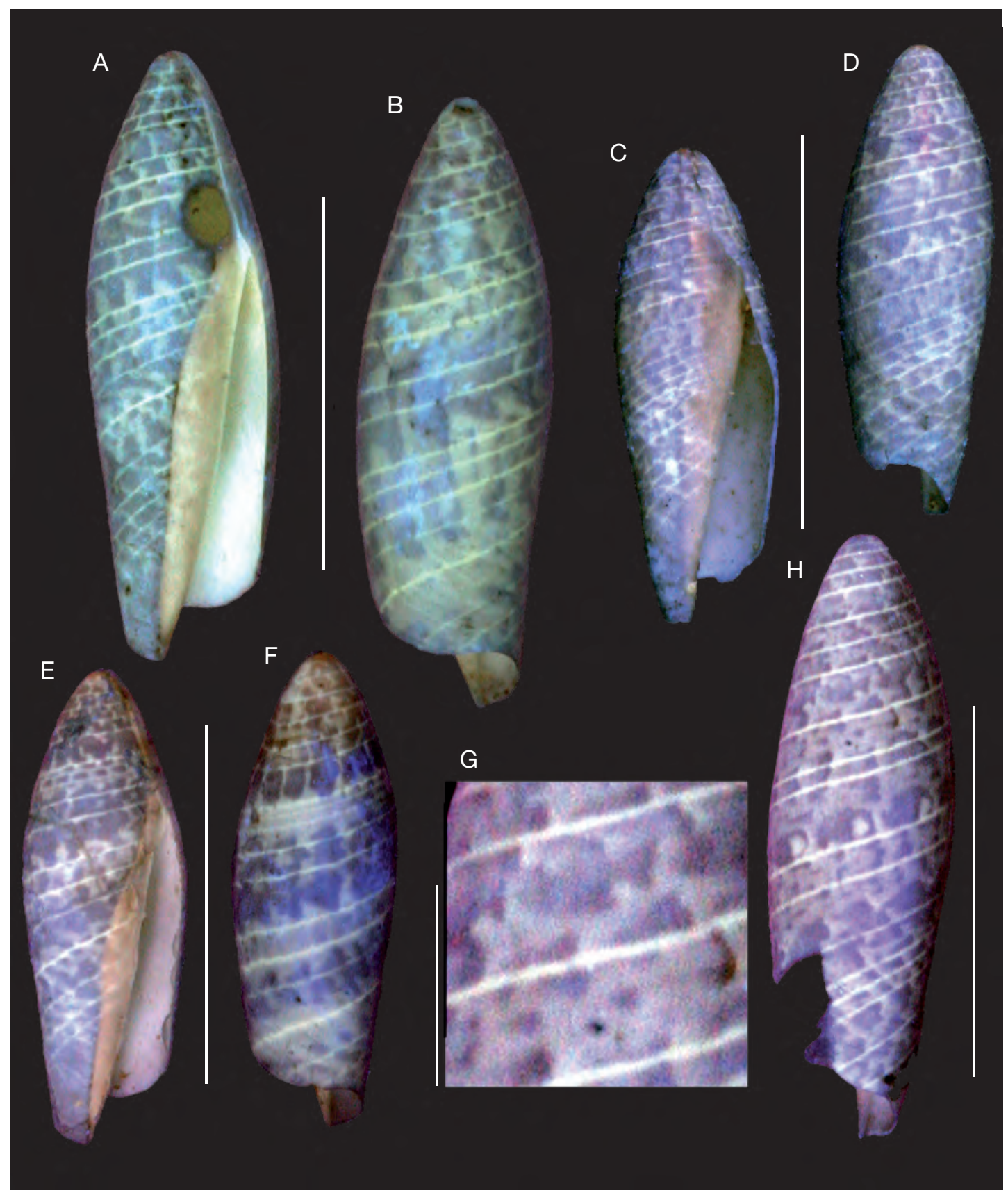

FIG. 19. - Seraphs peterjungi n. sp. under UV light: A, B, holotype MNHN A28578, Chaussy (Les Garennes), Val d'Oise, France, Lutetian; A, ventral view; B, dorsal view; C, D, paratype MNHN A28537 (Faullummel coll.), Chaussy (Les Garennes), Lutetian; C, ventral view; D, dorsal view; E, F, paratype MNHN A27273 (leg. Pacaud), Chaussy (Les Garennes), Lutetian; E, ventral view; F, dorsal view; G, H, paratype MNHN A28931 (leg. Pacaud), Chaussy (Les Garennes), Lutetian; G, detailed view of the dots; H, dorsal view. Scale bars: A-F, H, 10 mm; G, 2 mm. Photographs by C. Lemzaouda (MNHN). 
Type Locality. - Villiers-Saint-Frédéric (Yvelines, France), Lutetian (Middle Eocene).

TYPE MATERIAL. - Ovula fragilis: syntype(s) from Grignon (Yvelines, France), not found.

Ovula media: lectotype designated by Jung (1974) from the Deshayes collection and now deposited at the UCBL, not found; paralectotypes (UCBL, Deshayes coll.), not found.

A neotype designation is needed to clarify the taxonomic status of this species. A neotype from the locality Villiers-Saint-Frédéric (MNHN A28939, leg. Pacaud, Fig. 21A-F), near Grignon (Yvelines) is accordingly chosen here. This initiative conforms to the rules specified by the ICZN (1999: art. 75), as regards the designation of a neotype.

Other material eXamined. - See Appendix 1.

\section{DESCRIPTION}

Shell

Inflated shell up to $11 \mathrm{~mm}$ in height and $4 \mathrm{~mm}$ in diameter. Aperture long and narrow. Callus of inner lip clearly delineated, but weakly developed. Columella slightly bent backwards near the base. Outer lip thickened and extended above the apex. Outer lip forming an acute structure (Fig. 20B) hiding the actual apex (Jung 1974). Outer lip sinuous, prosocyrt on the abapical part and opisthocyrt on the adapical part of the shell (Fig. 20C). Siphonal notch moderately deep. Surface sculpture of narrow oblique grooves near the base (Fig. 20D).

\section{Colour pattern}

The residual pattern is composed of two levels of residual pigmentation: dark lines on a lighter background. These lines are axial and from wavy to zigzagging (Fig. 21A, G, H, L-N). They usually cover the outer lip and the extremities of the shell. On the median part, the shells show a gradual transition from wavy lines to a chessboard pattern (Meinhardt 1998) (Fig. 21A, B, D, E).

\section{VARIABILITY}

The lines can be more or less wavy. Some specimens have only axial straight lines on the whole shell surface (Fig. 21C, J, K), while other specimens have a chessboard pattern on the median part of the shell.

\section{Subgenus Miniseraphs Jung, 1974}

TYPE SPECIES. - Terebellum (Seraphs) eratoides Cossmann, 1889 by original designation. Lutetian, Paris Basin.

\section{Diameza (Miniseraphs) eratoides \\ (Cossmann, 1889)}

(Figs 20F-J; 22)

Terebellum (Seraphs) eratoides Cossmann, 1889: 98, 99, pl. 3, figs 7, 8;

Terebellum (Seraphs) eratoides - Cossmann 1904: 46. Cossmann \& Pissarro 1905: 97, pl. 16, fig. 36; 1911 : pl. 32, fig. 158-7.

Seraphs (Miniseraphs) eratoides - Jung 1974: 30, pl. 9, figs 10-12, text-figs 19, 20. — Le Renard 1992: 6. — Le Renard \& Pacaud 1995: 112. — Pacaud \& Le Renard 1995: 162.

Type locality. - Chaussy, Les Garennes (Val d'Oise, France), Lutetian (Middle Eocene).

TYPE MATERIAL. — Lectotype designated by Jung (1974) from the Bernay collection; paralectotype (Boutillier coll.) from Vaudancourt (Oise), not found.

The type material of this species has not been found in the Bernay collection, now deposited at the UCBL. A neotype designation is needed to clarify the taxonomic status of this species. A neotype from the type locality (MNHN A28932, Faullummel coll., Fig. 22A-D) is accordingly chosen here. This initiative conforms to the rules specified by the ICZN (1999: art. 75), as regards the designation of a neotype.

Other Material EXAMined. - See Appendix 1.

\section{SHELL DESCRIPTION}

Shell up to $8 \mathrm{~mm}$ in height and up to $5 \mathrm{~mm}$ in diameter, very stout with wide apical angle (Fig. 20F-H). Aperture long and narrow. Callus of the inner lip clearly delineated, but weakly developed. Columella slightly bent backwards near the base. Outer lip thickened and forming a small protuberance at the apex (Fig. 20J). Outer lip slightly sinuous for the whole height in labral view (Fig. 20G). Siphonal notch moderately deep on the dorsal side. Faint oblique to spiral grooves near the base (Fig. 20I).

\section{COLOUR PATTERN DESCRIPTION}

The residual pattern is only composed of 2 levels of residual pigmentation: dark lines on a lighter 


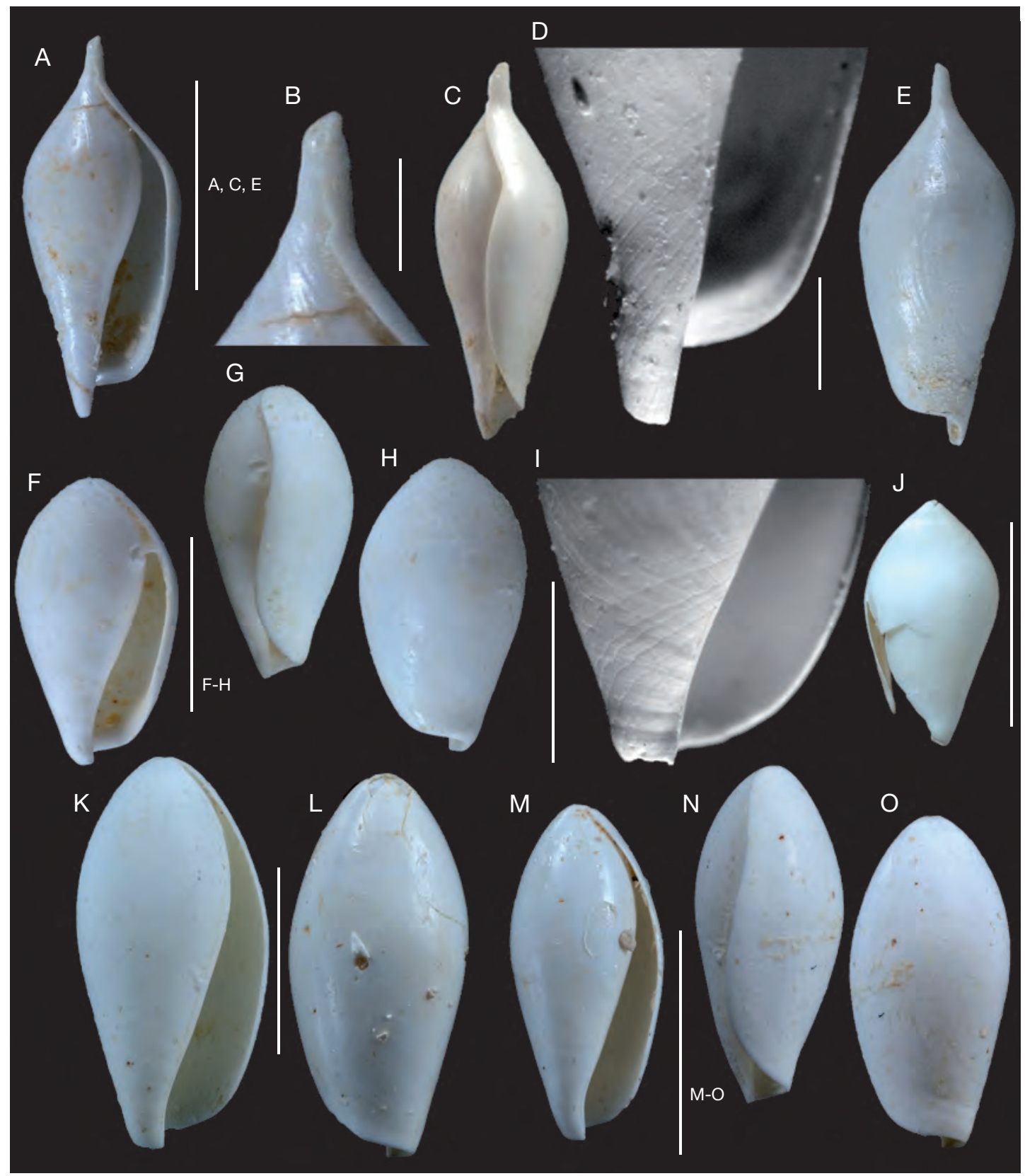

FIG. 20. - Diameza Deshayes, 1865 shells in normal light: A-E, Diameza (s.s.) fragilis (Defrance, 1825), MNHN A28784 (Faullummel coll.), Villiers-Saint-Frédéric, Yvelines, France, Lutetian; A, ventral view; B, detailed view of the apical part; C, labral view; D, detailed view of the oblique grooves; E, dorsal view; F-J, Diameza (Miniseraphs) eratoides (Cossmann, 1889); F-H, MNHN A28785 (Faullummel coll.), Chaussy (Les Garennes), Val d'Oise, France, Lutetian; F, ventral view; G, labral view; H, dorsal view; I, MNHN A28934 (detailed view of the oblique grooves) (leg. Pacaud), Fontenay-en-Vexin (Beauregard), Eure, France, Lutetian; J, MNHN B63254 (dorsal view) (Lhomme coll.), Hervelon, Marne, France, Lutetian; K-O, Diameza (Miniseraphs) Isabella (Bernay in Deshayes, 1865); K, L, MNHN A28782 (leg.Pacaud), Parnes, Oise, France, Lutetian; K, ventral view; L, dorsal view; M-O, MNHN A28783 (leg. Pacaud), Cauvigny, Oise, France, Lutetian; M, ventral view; N, labral view; O, dorsal view. Scale bars: A, C, E-H, J-O, 5 mm; B, D, 1 mm; I, 2 mm. Photographs by C. Lemzaouda (MNHN). 
background. These axial lines are wavy, but do not cover the whole shell surface. Most specimens show a combination of two morphologies: 1) dark wavy lines, sometimes forming zigzags (Fig. 22E), which are visible on the extremities of the shell and near the outer lip; 2) on the median part of the shell, a chessboard morphology (Fig. 22A, C, E, G, I, J), as defined by Meinhardt (1998: fig. 5.6). The chessboard pattern can appear as "light dots" on a darker background on poorly preserved shells (Fig. 22G, J).

\section{VARIABILITY}

The intraspecific variability is weak. Some specimens show numerous continuous wavy lines near the outer lip (Fig. 22E, F), while others show a chessboard pattern on the whole shell surface, except for the abapical and adapical extremities (Fig. 22G, H).

\section{Diameza (Miniseraphs) isabella}

(Bernay in Deshayes, 1865)

(Figs 20K-O; 23)

Terebellum isabella Bernay in Deshayes, 1865: 470, 471, pl. 92, figs 14-16.

Terebellum isabella - Bosatta et al. 1973: 189.

Terebellum (Seraphs) isabellae - Cossmann 1889: 98. Oppenheim 1896: 195 partim. - Cossmann 1904: 46. - Cossmann \& Pissarro 1911: pl. 32, fig. 158-6.

Diameza (Miniseraphs) isabella - Jung 1974: 30, 31, pl. 9, figs 13-18, text-figs 20, 21. — Le Renard 1992: 6. Le Renard \& Pacaud 1995: 112. — Pacaud \& Le Renard 1995: 162 .

TyPe LOCAlity. - Chaussy, Les Garennes (Val d'Oise, France), Lutetian (Middle Eocene).

TYPe MATERIAL. — Lectotype designated by Jung (1974) from the Bernay collection, and now deposited at UCBL, not found; paralectotype (UCBL, Deshayes coll.), not found. Accordingly, a neotype designation is needed to clarify the taxonomic status of this species. A neotype from the type locality (MNHN A28935, leg. Pacaud, Fig. 23A-D) is chosen here. This initiative conforms to the rules specified by the ICZN (1999: art. 75), as regards the designation of a neotype.

Other material examined. - See Appendix 1.

\section{DESCRIPTION}

Shell

Small shell up to $16 \mathrm{~mm}$ in height and up to $8 \mathrm{~mm}$ in diameter, inflated with wide apical angle. Aperture long and narrow. Callus of the inner lip clearly delineated, but weakly developed. Columella slightly bent backwards near the base. Outer lip thickened and extending to the apex (Fig. 20K). Outer lip prosocyrt on the abapical part and opisthocyrt on the adapical part in labral view (Fig. 20N). Siphonal notch moderately deep. Oblique grooves near the base of the shell.

\section{Colour pattern}

The colour pattern of the species is composed of 2 levels of pigmentation: dark axial wavy lines on a lighter background. The axial lines form some zigzags (Fig. 23). The zigzags cover mainly the median part of the shell. On the base and the apex, the lines remain straight or slightly sinuous, showing very weak curves (Fig. 23I-M, O, P). The width of the lines is almost homogenous. The space between them is equivalent to their width.

\section{VARIABILITY}

The specimens bear zigzags of greater (Fig. 23D) or lesser amplitude (Fig. 23I). Some specimens bear a gradual transition from wavy lines to a zigzag pattern (Fig. 23H, I), while others show an abrupt transition, probably due to a growth interruption (Fig. 23F, G). Wavy axial lines crossing and forming a localized grid, called meshwork (Fig. 23M, N) as defined by Meinhardt (1998: fig. 5.3c, d), have been observed too.

COMPARISONS OF THE THREE SPECIES OF DIAMEZA Shell

Diameza (s.s.) fragilis displays a distinctive feature, the acute apical structure (Fig. 20B). According to Jung (1974), this feature is used to distinguish Diameza from Miniseraphs. Diameza (s.s.) fragilis is however closely related to $D$. (Miniseraphs) in sharing a small and inflated shell, a wide apical angle and a sinuous outer lip (Fig. 20). Diameza (Miniseraphs) isabella is very similar to $D$. (M.) eratoides. Diameza (M.) isabella is more slender (Fig. 20F, K) and the adult specimens are twice 


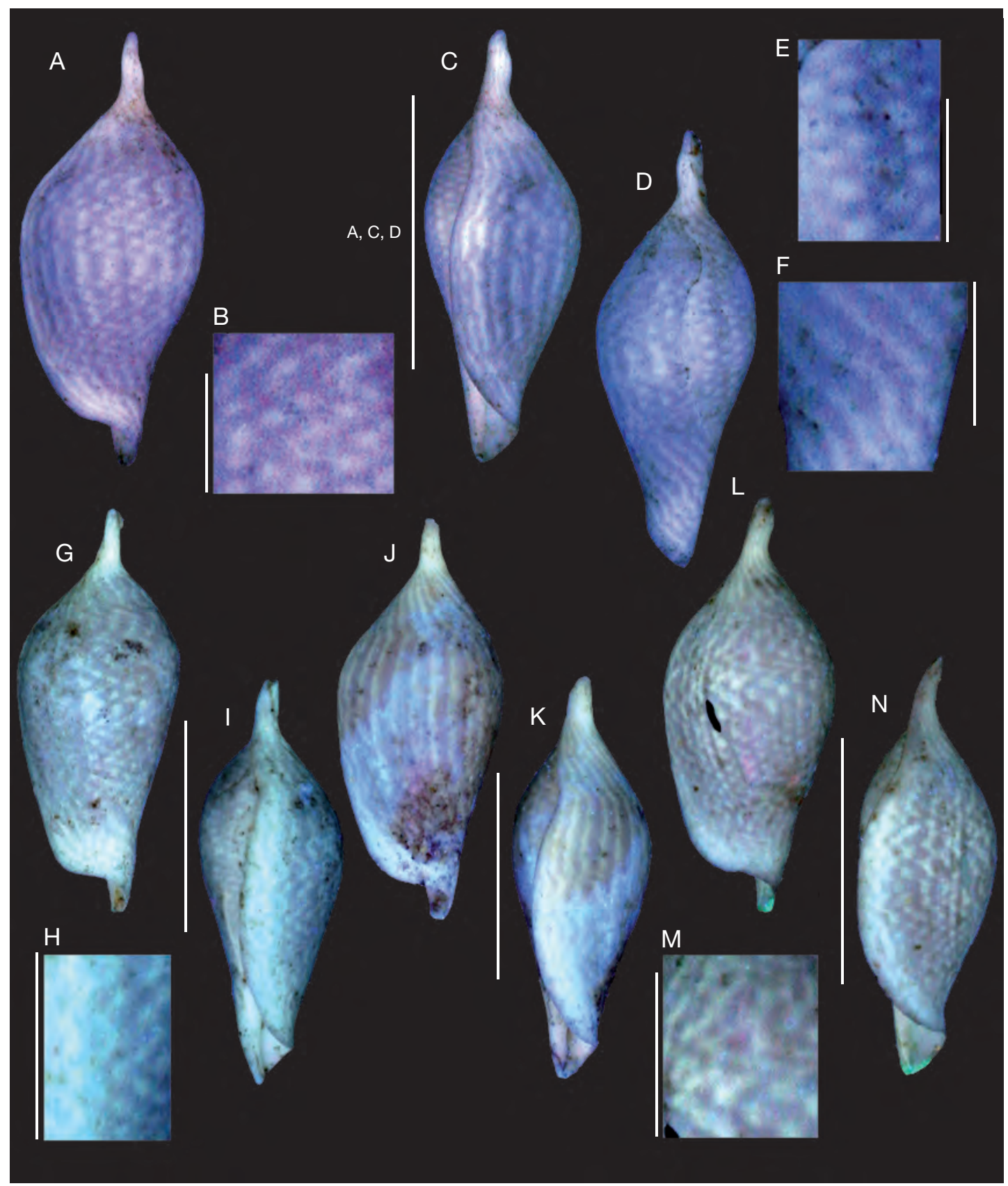

FIG. 21. - Diameza (s.s.) fragilis (Defrance, 1825) under UV light: A-F, neotype, MNHN A28939 (leg. Pacaud), Villiers-Saint-Frédéric, Yvelines, France, Lutetian; A, dorsal view; B, detailed view of the chessboard pattern; C, labral view; D, abapertural view; E, detailed view of the chessboard pattern; F, detailed view of the lines; G-I, MNHN A28940 (Faullummel coll.), Villiers-Saint-Frédéric, Lutetian; G, dorsal view; H, detailed view of the zigzagging lines; I, labral view; J, K, MNHN A28784 (Faullummel coll.), Villiers-Saint-Frédéric, Lutetian; J, dorsal view; K, labral view; L-N, MNHN A28942, Villiers-Saint-Frédéric, Lutetian; L, dorsal view; M, detailed view of the zigzagging lines; N, labral view. Scale bars: A, C-D, G, I-L, N, 5 mm; B, E, F, 1 mm; H, M, 2 mm. Photographs by C. Lemzaouda (MNHN). 


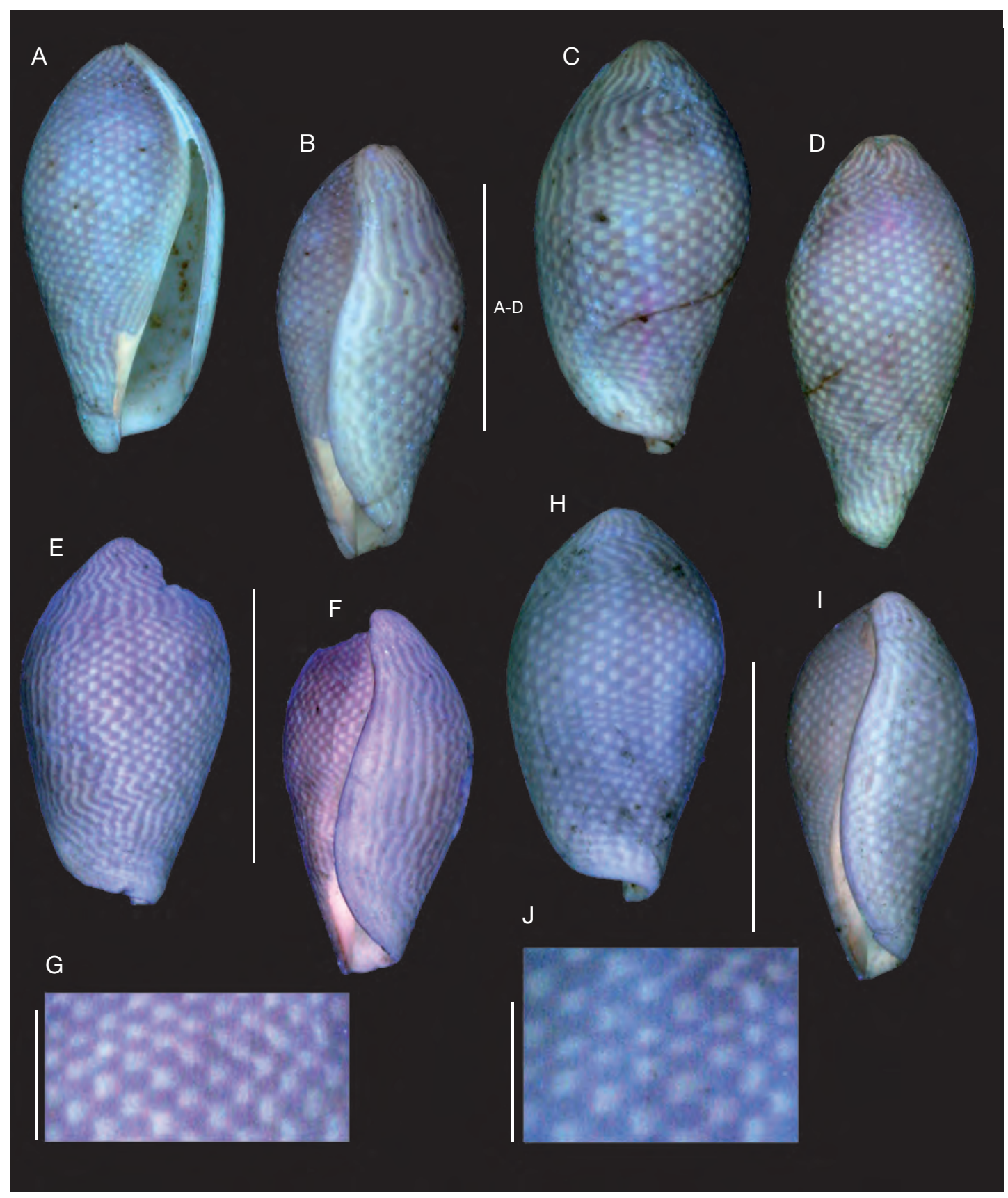

FIG. 22. - Diameza (Miniseraphs) eratoides (Cossmann, 1889) under UV light: A-D, neotype, MNHN A28932, Chaussy (Les Garennes), Val d'Oise, France, Lutetian; A, ventral view; B, labral view; C, dorsal view; D, abapertural view; E-G, MNHN A28934, Fontenay-enVexin, Eure, France, Lutetian; E, dorsal view; F, labral view; G, detailed view of the chessboard pattern; H-J, MNHN A28933, Fontenayen-Vexin, Lutetian; H, dorsal view; I, labral view; J, detailed view of the chessboard pattern. Scale bars: A-F, H-I, 10 mm; G, J, 2 mm. Photographs by C. Lemzaouda (MNHN). 


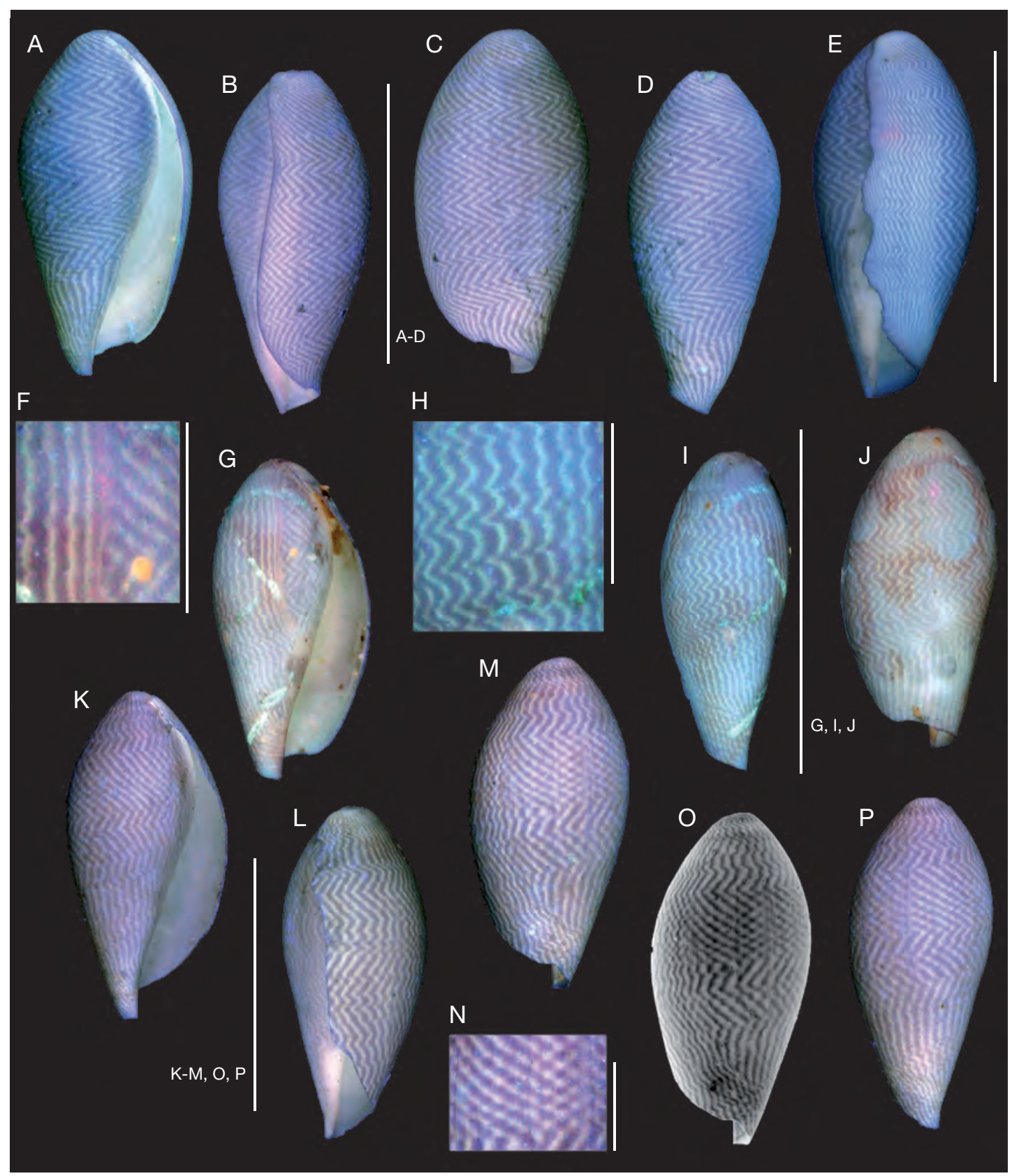

FIG. 23. - Diameza (Miniseraphs) isabella (Bernay, 1889) under UV light: A-D, neotype, MNHN A28935 (leg. Pacaud), Chaussy (Les Garennes), Val d'Oise, France, Lutetian; A, ventral view; B, labral view; C, dorsal view; D, abapertural view; E, MNHN A28938 (labral view) (leg. Pacaud), Chaussy (Les Garennes), Lutetian; F-J, MNHN A28937 (Faullummel coll.), Chaussy (Les Garennes), Lutetian; $\mathbf{F}$, detailed view of the axial and zigzaging lines; $\mathbf{G}$, ventral view; $\mathbf{H}$, detailed view of the axial lines; I, abapertural view; J, dorsal view; K-P, MNHN A28936, Chaussy (Les Garennes), Lutetian; K, ventral view; L, labral view; M, dorsal view; N, detailed view of the zigzaging axial lines; O, dorsal view in negative; P, abapertural view. Scale bars: A-E, G, I-M, O-P, 10 mm; F, H, N, 2 mm. Photographs by C. Lemzaouda (MNHN). 
as large as those of D. (M.) eratoides (Jung 1974). Furthermore, D. (M.) eratoides shows a small protuberance (Fig. 20J, rarely preserved) on the apex, missing in D. (M.) isabella.

\section{Residual colour pattern}

All species share a pattern composed of two levels of pigmentation. The colour pattern of Diameza (s.s.) fragilis (Fig. 21) is closely related to that of $D$. (Miniseraphs) eratoides (Fig. 22). It shares with $D$. (M.) eratoides a combination of two morphologies: 1) dark wavy lines visible on the extremities of the shell and near the outer lip; and 2) a chessboard pattern on the median part of the shell. Nevertheless, some shells of Diameza (s.s.) fragilis bear a residual pattern only composed of axial lines (Fig. 21J-K), lacking in $D$. (Miniseraphs) eratoides. Diameza (M.) eratoides differs from $D$. (M.) isabella by a chessboard pattern covering a large part of the shell. Moreover, the amplitude of the wave of each line is lower than that observed on Diameza (Miniseraphs) isabella (Fig. 23).

\section{Genus Paraseraphs Jung, 1974}

TYPE SPECIES. - Paraseraphs tetanus Jung, 1974 by original designation. Ypresian (Cuisian), Paris Basin.

\section{Paraseraphs tetanus Jung, 1974}

(Figs 24A-F; 25; 26)

Paraseraphs tetanus Jung, 1974: 34-36, pl. 9, fig. 26; pl. 10, figs 1-10, text-fig. 12, 26-28.

Terebellum fusiforme - d'Orbigny 1850: 314, no. 304. Pictet 1855: pl. 64, fig. 2. —Deshayes, 1865:470. — Mayer, 1866: 319, 332. - Newton, 1894: 97. - Cossmann, 1904: 43, 44, pl. 2, fig. 10; pl. 3, fig. 4. - Cossmann \& Pissarro, 1911: pl. 31, fig. 158-1. Non Lamarck, 1802.

Terebellum (s.s.) fusiforme - Cossmann 1889: 96 partim. Non Lamarck, 1802.

Paraseraphs placitus Merle, 1986: 32. Non Jung 1974.

Paraseraphs tetanus - Savazzi 1991: 324, fig. 13G. - Le Renard 1992: 6. — Le Renard \& Pacaud 1995: 112. — Pacaud \& Le Renard 1995: 162. — Pacaud 2008: 724, fig. 2C, D.
Type LOCAlity. — Cuise-la-Motte (Oise, France), Ypresian (Cuisian, Lower Eocene).

Type MATERIAL. - Holotype (NMB H15409); 3 paratypes (NMB H15408, H15405, H16502).

Other material eXamined. - See Appendix 1.

\section{DESCRIPTION}

Shell

Shell up to $38 \mathrm{~mm}$ in height and $8 \mathrm{~mm}$ in diameter, evolute with straight and almost parallel sides (Fig. 24A, C, D, F). Suture distinct on the adapical part (Fig. 24A, C, D, F). Aperture long and narrow. Callus of the inner lip well developed and well delineated. Columella bent backwards near the base of the shell (Fig. 24B, E). Outer lip slightly opisthocline and thickened on the adapical part. Outer lip not reaching directly to the apex, but bent towards the dorsal side of the shell (Fig. 24B, C, E, F). Callus of the inner lip, thin, extending on the spire towards the apex and forming a narrow band parallel to the outer lip. Siphonal notch moderately deep. No sculpture observed.

\section{Colour pattern}

The pattern is composed of 2 levels of colouration: dark elements on a lighter background (Fig. 25). The darker elements are usually very thin and form axial rows of dots (Fig. 25C, F, I) and segments (Fig. 25K). On the subsutural part of the last whorl and on the anal canal, a peculiar pattern can be distinguished. It corresponds to an oblique succession of darker and lighter "patches" (Fig. 25H, J, L, P, R). These "patches" are not true patches as defined in the part terminology, but are the result of the coalescence of axial segments.

\section{VARIABILITY}

Among 319 specimens from 5 localities (Cuisian), 304 (95.3\%) show a residual pattern under UV light (Table 1). Thus, these observations provide a good general survey of intraspecific variability of the pattern of this species.

The residual pattern of Paraseraphs tetanus shows strong variability (Fig. 26). The dots are variable in size and shape from axially elongated to circular or triangular shape or indeed completely distorted (Fig. 26I, J). Their density on the shell, and the degree 


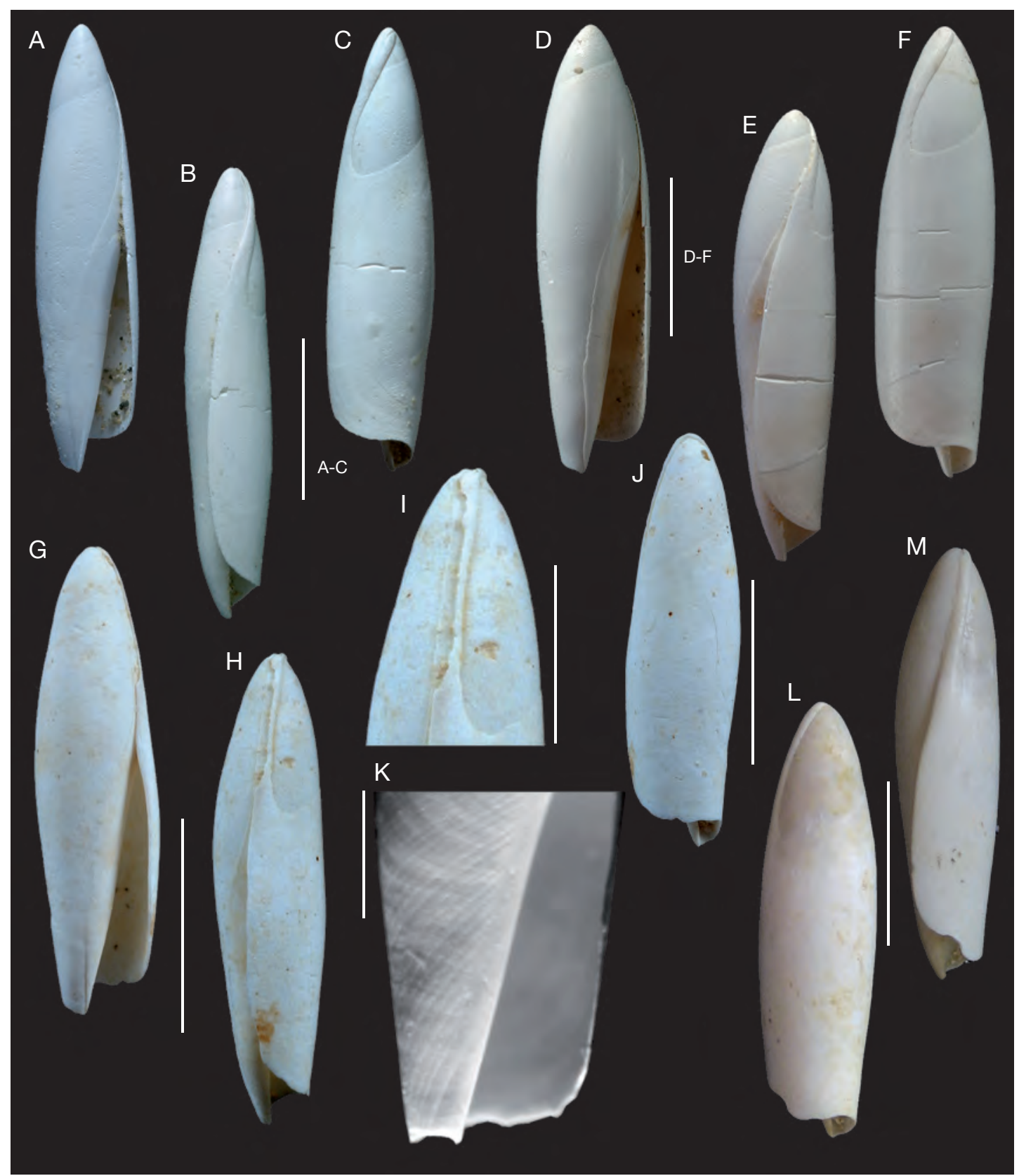

FIG. 24. - Paraseraphs Jung, 1974 shells in normal light: A-F, P. tetanus Jung, 1974; A-C, MNHN A28579 (Faullummel coll.), SaintGobain, Aisne, France, Ypresian (Cuisian); A, ventral view; B, labral view; C, dorsal view; D-F, MNHN A28787 (Ferry coll.), CuiseLamotte (Butte-des-Usages), Oise, France, Ypresian (Cuisian); D, ventral view; E, labral view; F, dorsal view; G-M, P. placitus Jung, 1974; G-J, MNHN A28786 (Lhomme coll.), Chaussy (Les Garennes), Val d'Oise, France, Lutetian; G, ventral view; H, labral view; I, detailed view of the apical part; J, dorsal view; K, MNHN A28962 (detailed view of the basal part) (leg. Pacaud), Fercourt, Oise, France, Lutetian; L, M, MNHN A28774 (Lhomme coll.), Chaussy (Les Garennes), Lutetian; L, dorsal view; M, labral view. Scale bars: A-H, J, L, M, 10 mm; I, 5 mm; K, 2 mm. Photographs by C. Lemzaouda (MNHN). 
of coalescence, can be weak to very considerable. Some shells bear only a few dark dots disseminated on the surface (Fig. 26F, G, K). When the density of dots increases, they form some thin axial rows (Fig. 26D, E, H) or, by coalescence, compressed segments (Fig. 26A-C) or sinuous stripes (Fig. 26O$\mathrm{R})$. In spite of this variability, two representative morphological types can be distinguished (types 1 and 2, Fig. 27). Type 1 corresponds to the most abundant portion of the analysed specimens. The pattern of the type 1 is composed of axial rows of more or less coalescent dark dots (Fig. 26A-F). Type 2 bears some sinuous and more or less discontinuous axial stripes (Fig. 26O-R). Several shells show a morphology intermediate between both types (Figs 26G-K, L-N; 27). The relative abundance of these morphologies is given in Figure 27. The Figure 26 illustrates each type described above with several intermediate specimens, showing the impossibility of separating one type from another, as different species.

\section{Paraseraphs placitus Jung, 1974}

(Figs 24G-M; 28)

Paraseraphs placitus Jung, 1974: 38, pl. 10, figs 13-18, text-fig. 28.

Terebellum fusiforme - Sowerby 1821: 157, pl. 287. De Blainville 1828: 276. — Deshayes 1835: 738, pl. 95, figs 30, 31. Non Lamarck, 1802.

Terebellum (s.s.) fusiforme-Glibert 1938: 65, 66, pl. 2, fig. 7 . —Cossmann 1889: 96 partim. Non Lamarck, 1802.

Terebellum (s.s.) fusiforme postconicum Cossmann, 1904: 44. Non de Gregorio, 1880.

Paraseraphs placitus-Dolin et al. 1980: 28. — Le Renard 1992: 6. — Le Renard \& Pacaud 1995: 112. — Pacaud \& Le Renard 1995: 162.

TyPe LOCAlity. - Les Garennes, Chaussy (Val d'Oise, France), Lutetian (Middle Eocene).

TYPE MATERIAL. - Holotype (NMB H14491); paratype (NMB H10539), Les Garennes, Chaussy (Val d'Oise, France); paratypes (UCBL coll. Deshayes), Mouchy-leChâtel (Oise) and Parnes (Oise), not found.

Other material examined. - See Appendix 1.

\section{DESCRIPTION}

Shell

Shell up to $30 \mathrm{~mm}$ in height and $7 \mathrm{~mm}$ in diameter, moderately slender and evolute with distinct suture. Aperture long and narrow. Callus of the inner lip well developed, well delineated, extending to the apex and forming a narrow band parallel to the outer lip (Fig. 24I). Basal part of the columella bent backwards. Outer lip, almost straight and slightly opisthocline (Fig. $24 \mathrm{H}, \mathrm{M}$ ), not thickened on the basal part of the shell. Adapical part of the outer lip thickened and extending from the adapical end of the aperture, towards the apex (Fig. 24H), or bent towards the dorsal side (Fig. 24M). Siphonal notch moderately deep. Sculpture with a few oblique grooves near the base of the shell (Fig. 24K).

\section{Colour pattern}

Paraseraphs placitus has numerous and irregular dots with 2 levels of residual coloration on a lighter background (Fig. 28). The first level consists of triangular spots, darker than the background. These spots, more or less distorted, are orientated towards the growing edge (Fig. 28C, F, L). The second level consists of fluorescent spots with fuzzy borders, lighter than the background. These light spots, adjacent to the base of dark spots, are narrow and directed towards the inner lip in ventral view (Fig. 28C, F, L). They are variable in size. These two components form the dots. The density of dots is generally low. Also, a peculiar pattern can be distinguished on the adapical part of the outer lip: an oblique succession of darker and lighter "patches" (Fig. 28B, D, E, M, N). These "patches" are probably the result of the coalescence of the dark axial segments (Fig. 28D).

\section{VARIABILITY}

Sometimes the darker spots of the dots are larger near the edge of the outer lip (Fig. 28B, C, P) and are coalescent.

\section{Paraseraphs armoricus (Vasseur, 1882)}

(Figs 29A-C; 30)

Terebellum armoricum Vasseur, 1881: 174, no. 22 and p. 245, no. 43 (nomen nudum). 


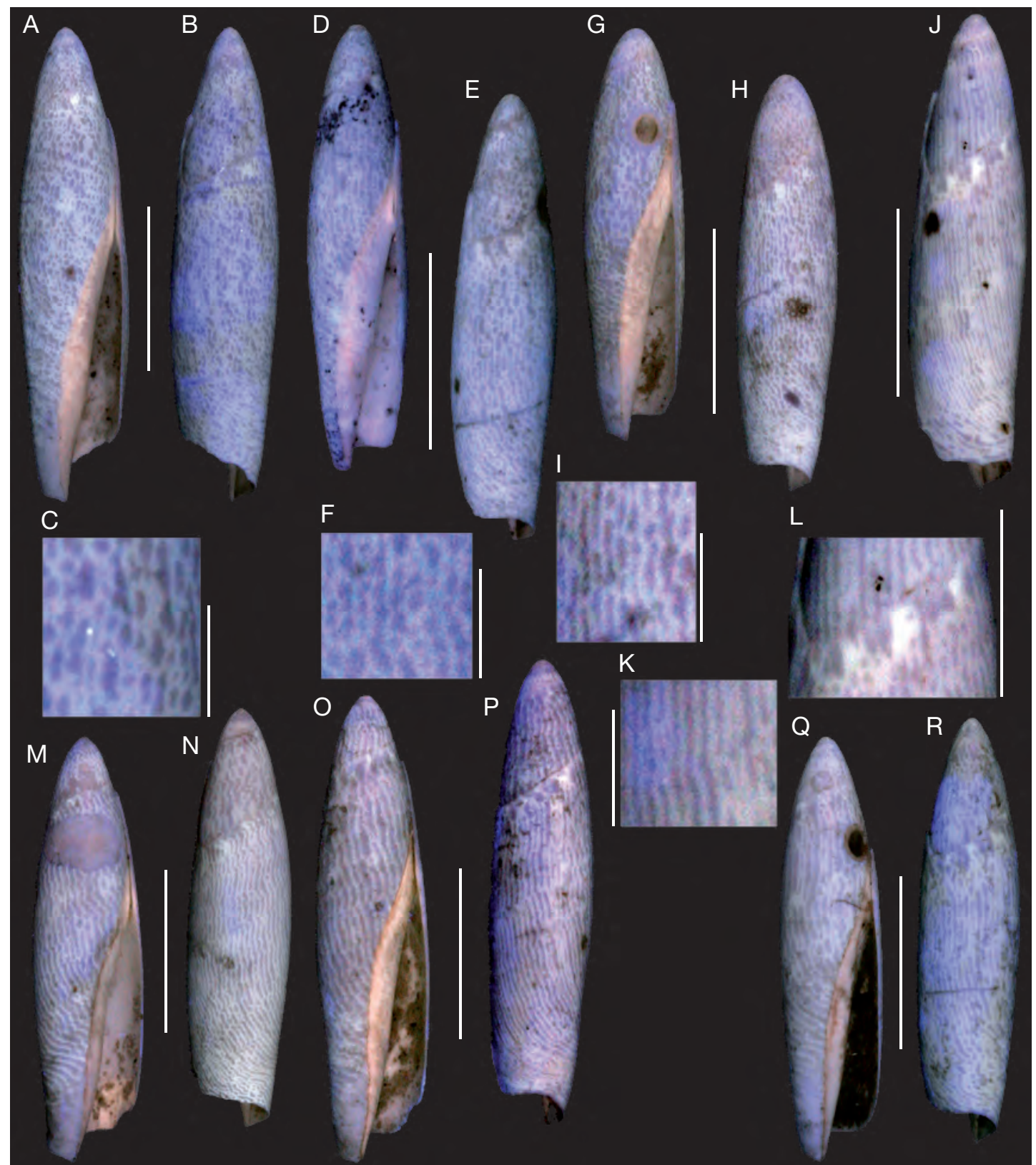

FIG. 25. - Paraseraphs tetanus Jung, 1974 under UV light: A-C, MNHN A28946, Cuise-Lamotte (Butte-des-Usages), Oise, France, Ypresian (Cuisian); A, ventral view; B, dorsal view; C, detailed view of the rows of dots; D-F, MNHN A28945, Saint-Gobain, Aisne, France, Ypresian (Cuisian); D, ventral view; E, dorsal view; F, detailed view of the the rows of dots; G-I, MNHN A28947, Cuise-Lamotte (Butte-des-Usages), Ypresian (Cuisian); G, ventral view; H, dorsal view; I, detailed view of the the rows of dots; J-L, MNHN A28948, Cuise-Lamotte (Butte-des-Usages), Ypresian (Cuisian); J, dorsal view; K, detailed view of the rows and lines; $\mathbf{L}$, detailed view of the subsutural part; M, N, MNHN A28943, Cuise-Lamotte (Butte-de-Usages), Ypresian (Cuisian); M, ventral view; N, dorsal view; O, P, MNHN A28941, Cuise-Lamotte (Butte-des-Usages), Ypresian (Cuisian); O, ventral view; P, dorsal view; Q, R, MNHN A28944, Cuise-Lamotte (Butte-des-Usages), Ypresian (Cuisian); Q, ventral view; R, dorsal view. Scale bars: A, B, D, E, G, H, J, M-R, 10 mm; C, F, I, K, 2 mm; L, 5 mm. Photographs by C. Lemzaouda (MNHN). 


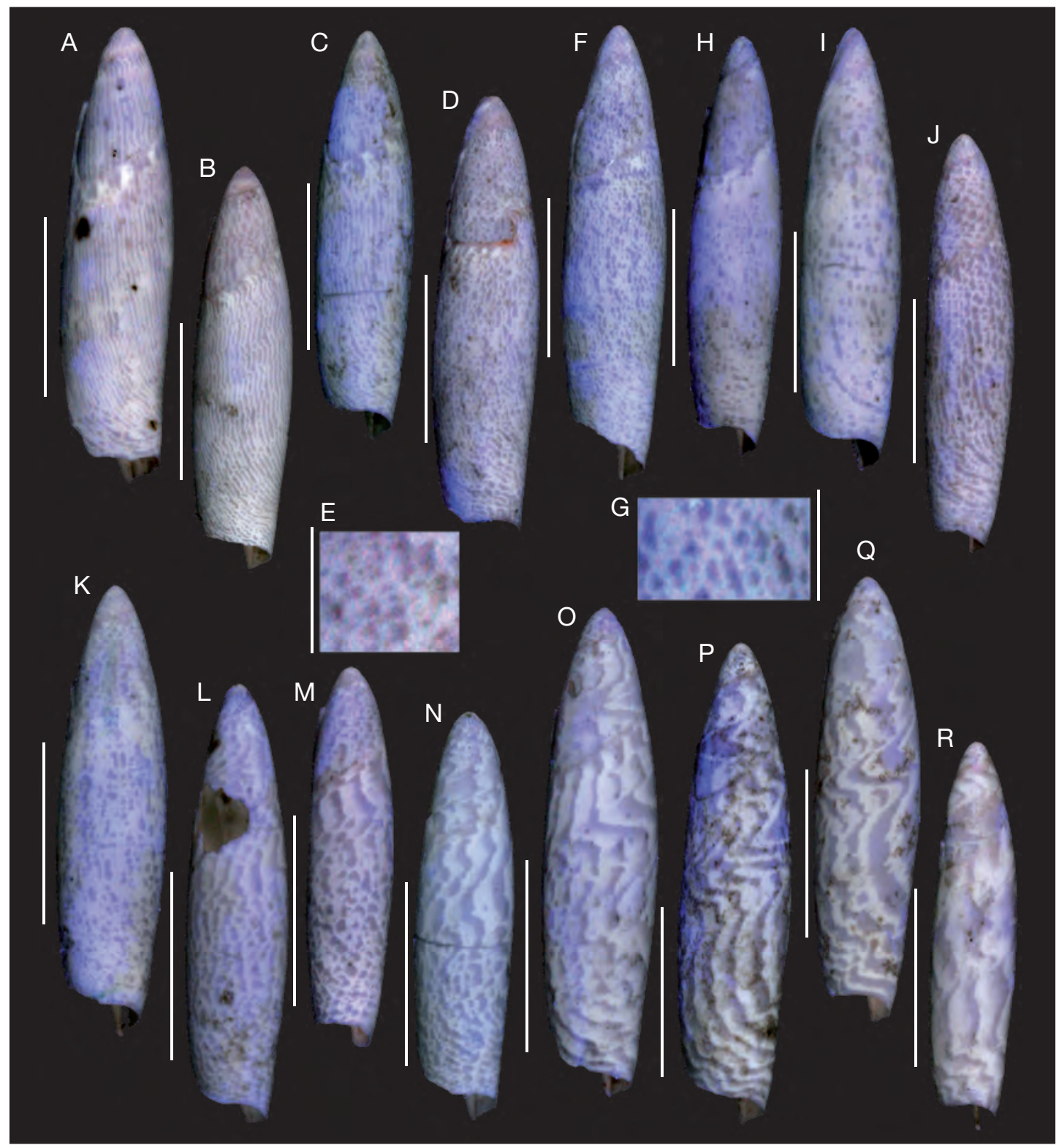

FIG. 26. - Variability of Paraseraphs tetanus Jung, 1974 in dorsal view and under UV light: A, MNHN A28948, Cuise-Lamotte (Butte-desUsages), Oise, France, Ypresian (Cuisian); B, MNHN A28943, Cuise-Lamotte (Butte-des-Usages), Ypresian (Cuisian); C, MNHN A28944, Cuise-Lamotte (Butte-des-Usages), Ypresian (Cuisian); D, E, MNHN A28952, Cuise-Lamotte (Butte-des-Usages), Ypresian (Cuisian); E, detailed view of the dots; F, G, MNHN A28946, Cuise-Lamotte (Butte-des-Usages), Ypresian (Cuisian); G, detailed view of the dots; $\mathbf{H}, \mathbf{M N H N}$ A28949, Cuise-Lamotte (Butte-des-Usages), Ypresian (Cuisian); I, MNHN A28579 (Faullummel coll.), Saint-Gobain, Aisne, France, Ypresian (Cuisian); J, MNHN A28953, Cuise-Lamotte (Butte-des-Usages), Ypresian (Cuisian); K, MNHN A28956 (Faullummel coll.), Saint-Gobain, Ypresian (Cuisian); L, MNHN A28954, Cuise-Lamotte (Butte-des-Usages), Ypresian (Cuisian); M, MNHN A28955, Cuise-Lamotte (Buttedes-Usages), Ypresian (Cuisian); N, MNHN A28958 (Faullummel coll.), Saint-Gobain, Ypresian (Cuisian); O, MNHN A28951, Cuise-Lamotte (Butte-des-Usages), Ypresian (Cuisian); P, MNHN A28950, Cuise-Lamotte (Butte-des-Usages), Ypresian (Cuisian); Q, MNHN A28957, Cuise-Lamotte (Butte-des-Usage), Ypresian (Cuisian); R, MNHN A28959 (Faullummel coll.), Saint-Gobain, Ypresian (Cuisian); A-G, Type 1; H-N, intermediaries 1-2; O-R, Type 2. Scale bars: A-D, F, H-R, 10 mm; E, G, 2 mm. Photographs by C. Lemzaouda (MNHN). 
Terebellum armoricum Vasseur, 1882: pl. 2, fig. 20; pl. 3, fig. 55.

Terebellum cylindricum Cailliaud, 1856: 42 (nomen nudum). - Cailliaud in Vasseur 1881: 232 (nomen nudum).

Terebellum fusiforme - Cailliaud 1856: 42. - Vasseur 1881: 232. Non Lamarck, 1802.

Terebellum (s.s.) armoricense - Cossmann 1898: 340, pl. 8, fig. 10 and 15, unjustified emendation; 1904: 44.

Terebellum armoricensis - Cossmann 1917: pl. 2, fig. 20; pl. 3, fig. 55.

Paraseraphs armoricensis - Jung 1974: 36, 37, pl. 9, figs 19-25, text-fig. 28.

TYPE LOCALITY. - Saffré, Bois-Gouët (Loire-Atlantique, France), Bartonian (Middle Eocene).

Type Material. - The type material of Vasseur (1882) was lost (Cossmann 1898). Accordingly, Cossmann (1898: pl. 8, figs 10,15) designated a neotype from the Dumas collection deposited in MNHN, but this specimen has not been found either. Later, Jung (1974: 36) wrongly considered the neotype of Cossmann to be the holotype of this species.

Other material EXAmined. - See Appendix 1.

\section{SHELL DESCRIPTION}

Shell $73 \mathrm{~mm}$ in height and $13 \mathrm{~mm}$ in diameter, slender and elongated. Shell evolute with distinct suture. Aperture long and narrow. Callus of the inner lip well developed and clearly delineated (Fig. 29A, B). Abapical part of the columella bent backwards. Outer lip, almost straight (Fig. 29C), not thickened except near the adapical end of the aperture. Outer lip running towards the apex and slightly bent on the dorsal side of the shell (following Jung [1974], our material being broken). Siphonal notch moderately deep on the dorsal side. No sculpture on the surface of the shell.

\section{COLOUR PATTERN DESCRIPTION}

Paraseraphs armoricus bears numerous and variablesized dots on a lighter background (Fig. 30). These dots, generally circular, spread over the whole surface of the shell. They show 2 levels of residual pigmentation (Fig. 30B, C, E): 1) round dark spots orientated toward the inner lip; and 2) white fluo-

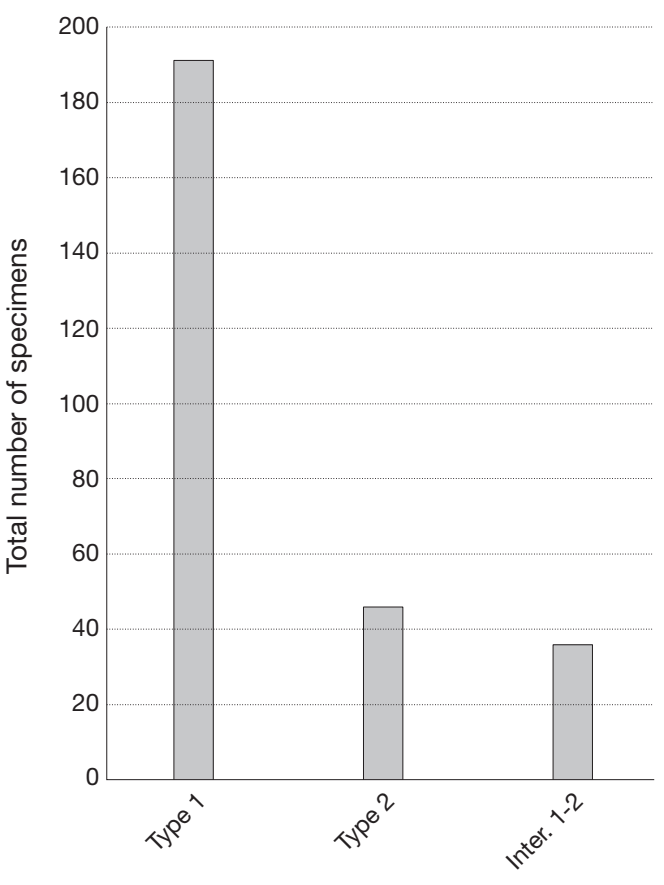

Pattern types

FIG. 27. - Distribution of the pattern types with their intermediaries (Inter.) in Paraseraphs tetanus Jung, 1974.

rescent, crescent-like spots orientated towards the growing edge. These 2 components form the dots. The density of dots is low, with little coalescence (Fig. 30B).

\section{COMPARISONS OF THE THREE SPECIES}

OF PARASERAPHS: P. TETANUS, P. PLACITUS

AND $P$. ARMORICUS

\section{Shell}

These species of Paraseraphs are easily distinguishable from the species of Seraphs by their evolute spire (Figs 24; 29). Moreover, the shells are usually more slender. According to our observations, several differential characters attributed by Jung (1974) to distinguish Paraseraphs tetanus and P. placitus seem to be erroneous. Jung (1974) believed that $P$. tetanus is more slender than $P$. placitus. In fact, the shape of $P$. tetanus is variable and some specimens can be as inflated as P. placitus (Fig. 24F, L). Furthermore, 
Jung (1974) suggested that, on the posterior part of the shell, the outer lip of $P$. tetanus is bent towards the dorsal side, while that of $P$. placitus runs directly to the apex. For $P$. tetanus, his observations seem correct, but in $P$. placitus, the outer lip can continue directly to the apex or can be bent towards the dorsal side (Fig. 24H, M). Accordingly, this character is not consistent to distinguish the two species. On the other hand, contrary to Jung assumptions, the shell of $P$. tetanus does not show oblique grooves near the base. The Bartonian species $P$. armoricus is very similar to the other species, but much bigger (Fig. 29A-D).

\section{Residual colour pattern}

The dots constituting the pattern of $P$. placitus (Fig. 28) appear very similar to those of $S$. volutatus, S. sopitus and S. olivaceus (Figs 7-10). However, the dots are clearly ordered in these Seraphs, while no axial rows of dots have been observed in P. placitus. Regarding P. armoricus (Fig. 30), the orientation of the two components of the dots is inversed in comparison to P. placitus and even Seraphs. The darker spots are orientated towards the outer lip in P. armoricus and towards the inner lip in P. placitus. Furthermore, the shape of the dots is obviously different between $P$. placitus and $P$. armoricus. It is generally triangular for P. placitus (Fig. 28C, F, L), while it is circular for $P$. armoricus (Fig. $30 \mathrm{~B}, \mathrm{E}$ ). The pattern of $P$. tetanus is quite variable, but differs sharply by the occurrence of axial rows and by lacking of white fluorescent spots (Fig. 25).

Using shell characters, it is difficult to separate these three species of Paraseraphs, while using residual colour pattern we can obviously observe differences justifying their distinction.

\section{Paraseraphs praecedens n. sp.} (Fig. 29E, F)

TyPe LOCALITY. - Abbecourt (Oise), France, Thanetian (Upper Paleocene), biozone NP9.

Type Material. - Holotype (MNHN A05707, leg. Pacaud)

Etymology. - As the precursor of the Eocene Paraseraphs.
DESCRIPTION OF THE HOLOTYPE (FIG. 29E, F) Shell $19 \mathrm{~mm}$ in height and $7 \mathrm{~mm}$ in diameter, inflated and evolute with distinct suture. Spire short and blunt. Aperture long and narrow. Callus of the inner lip not preserved. Basal part of the columella and outer lip not preserved. No sculpture on the surface of the shell. No residual pattern observed under UV light (shell too poorly preserved).

\section{COMPARISONS OF THE SHELLS}

This species is easily distinguishable from the members of Seraphs by its evolute spire. Within Paraseraphs, although the shell of Paraseraphs praecedens n. sp. is incompletely preserved, it seems clearly stouter than the other species (Fig. 29D-F). Also, it is the smallest species of the genus.

\section{DISCUSSION}

From the Thanetian, Paraseraphs praecedens n. sp. is the oldest record of Paraseraphs for the world and the oldest record for the Seraphsidae in Europe. Previously, the oldest European occurrence of the Seraphsidae was Paraseraphs tetanus from the Ypresian (Cuisian, biozone NP 12) of the Paris Basin. Another species in this family is recorded in the ?Late Paleocene-Early Eocene, Seraphs minus (Vincent, 1913) from Angola (Landana beds, Cabinda, West Africa). Jung (1974) regarded it as a nomen dubium, because the two syntypes "represent the immature stage of some species of Seraphs". However, although this species is only based on young specimens, it should be considered as one of the oldest records of the Seraphsidae, along with $P$. praecedens n. sp.

\section{GENERAL DISCUSSION}

So far, the colour patterns of the Seraphsidae have never been recorded; except in the single reference (concerning Seraphs volutatus) by Jung (1974): "Most of the perfectly preserved shells from the middle Eocene of Villiers-Saint-Frédéric near Paris show remnants of the color pattern which consists of many small, somewhat irregular dots". Accordingly, the present study provides new information on the evolution of the pattern of the Seraphsidae, on the intraspecific variability of the studied spe- 


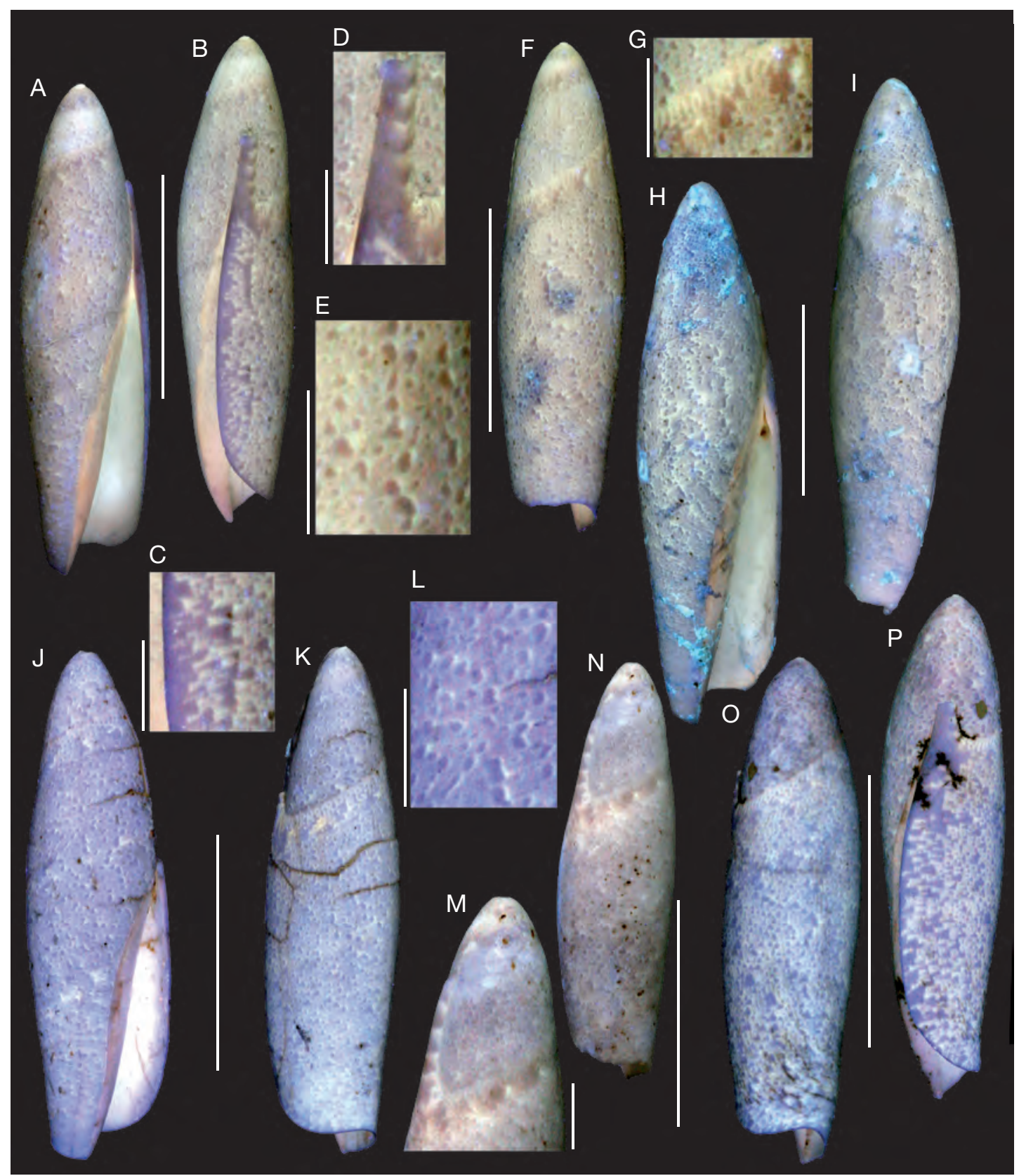

FIG. 28. - Paraseraphs placitus Jung, 1974 under UV light: A-G, MNHN A28961 (leg. Pacaud), Fercourt, Oise, France, Lutetian; A, ventral view; B, labral view; C, detailed view of the outer lip; D, detailed view of the adapical part of the outer lip; E, detailed view of the dots; F, dorsal view; G, detailed view of the subsutural part; H, I, MNHN A28960 (leg. Pacaud), Parnes, Oise, France, Lutetian; H, dorsal view; I, abapertural view; J-L, MNHN A28963 (Ballot coll.), Grignon, Yvelines, France, Lutetian; J, ventral view; K, dorsal view; L, detailed view of the dots; M, N, MNHN A28966 (Boule coll.), Chaussy (Les Garennes), Val d'Oise, France, Lutetian; M, detailed view of the apical part; N, dorsal view; O, P, MNHN A28964 (Ballot coll.), Grignon, Lutetian; O, dorsal view; P, labral view. Scale bars: A, B, F, H-K, N-P, 10 mm; C-E, G, L, M, 2 mm. Photographs by C. Lemzaouda (MNHN). 


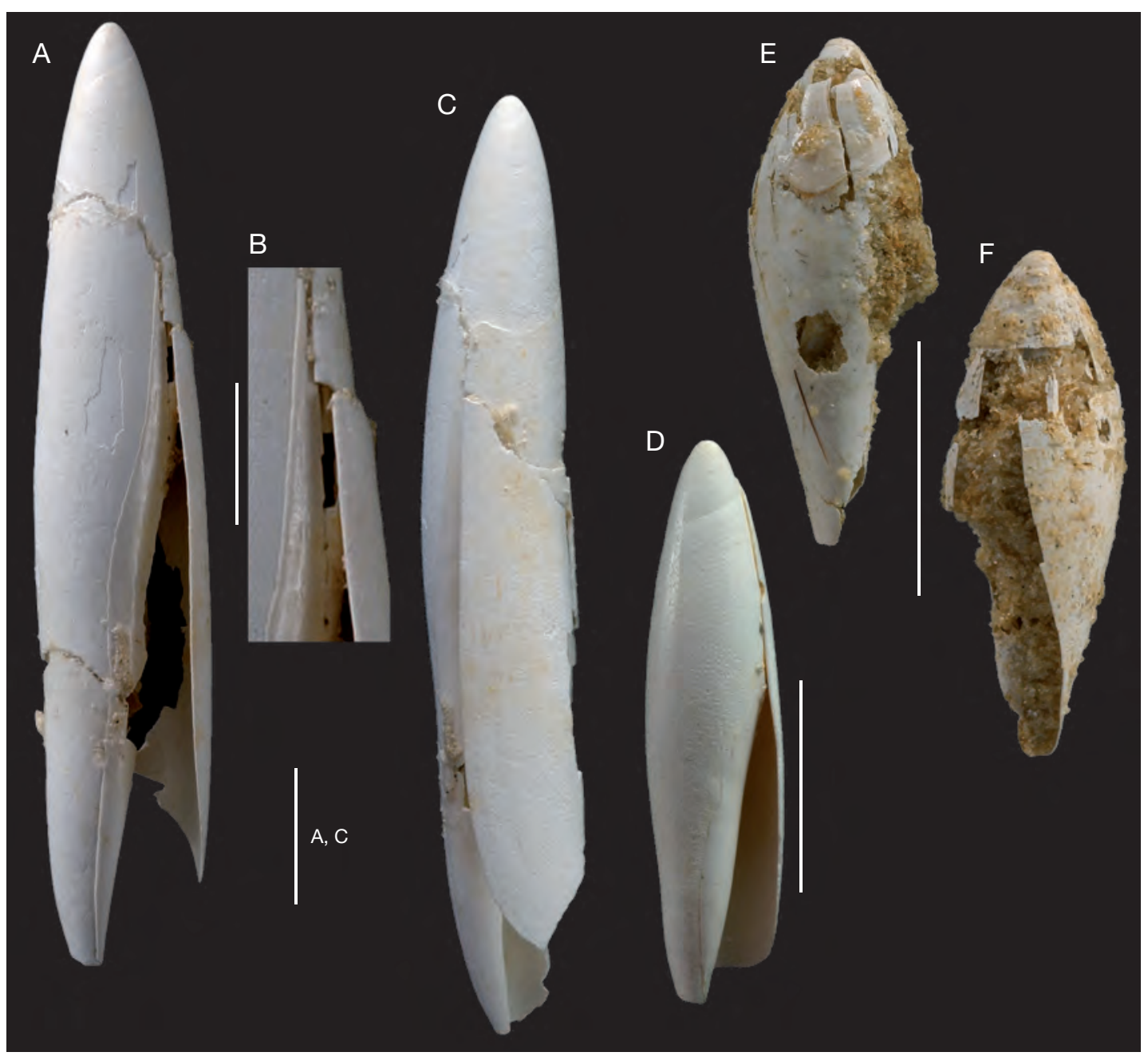

FIG. 29. - Paraseraphs Jung, 1974 shells in normal light: A-C, P. armoricus (Vasseur, 1882), MNHN A28788 (leg. Pacaud), Saffré (Bois-Gouët), Loire-Atlantique, France, Bartonian; A, ventral view; B, detailed view of the adapical part of the aperture; C, labral view; D, P. tetanus Jung, 1974, MNHN A29224 (ventral view) (Ferry coll.), Cuise-Lamotte, Oise, France, Ypresian (Cuisian), in comparison to $P$. armoricus and $P$. praecedens n. sp.; E, F, P. praecedens n. sp., holotype MNHN A05707 (leg. Pacaud), Abbecourt, Oise, France, Thanetian; E, ventral view; F, dorsal view. Scale bars: A, C, D-F, 10 mm; B, 5 mm. Photographs by C. Lemzaouda (MNHN).

cies, on their stratigraphic range (Fig. 31) and on the systematics on the family.

\section{EVOLUTION OF THE COLOUR PATTERN} OF THE SERAPHSIDAE THROUGH TIME

Most of the morphologies constituting the colour pattern of the Recent species Terebellum terebellum (Figs $1 ; 2$ ) were already present in Palaeogene species (dots with 2 levels of residual pigmentation, rows of dots, spiral lines). There is no significant difference, except for the occurrence of zigzags and chessboard pattern only recorded in the genus Diameza (Figs 21; 22). Dockery (1980) assumed that Eocene molluscs of the Moodys Branch Formation exhibit colour patterns that still persist in living representatives of the same family or genus. The same can be said for the Palaeogene Seraphsidae, and from the Early Eocene to the Recent few changes in pattern are recorded. 


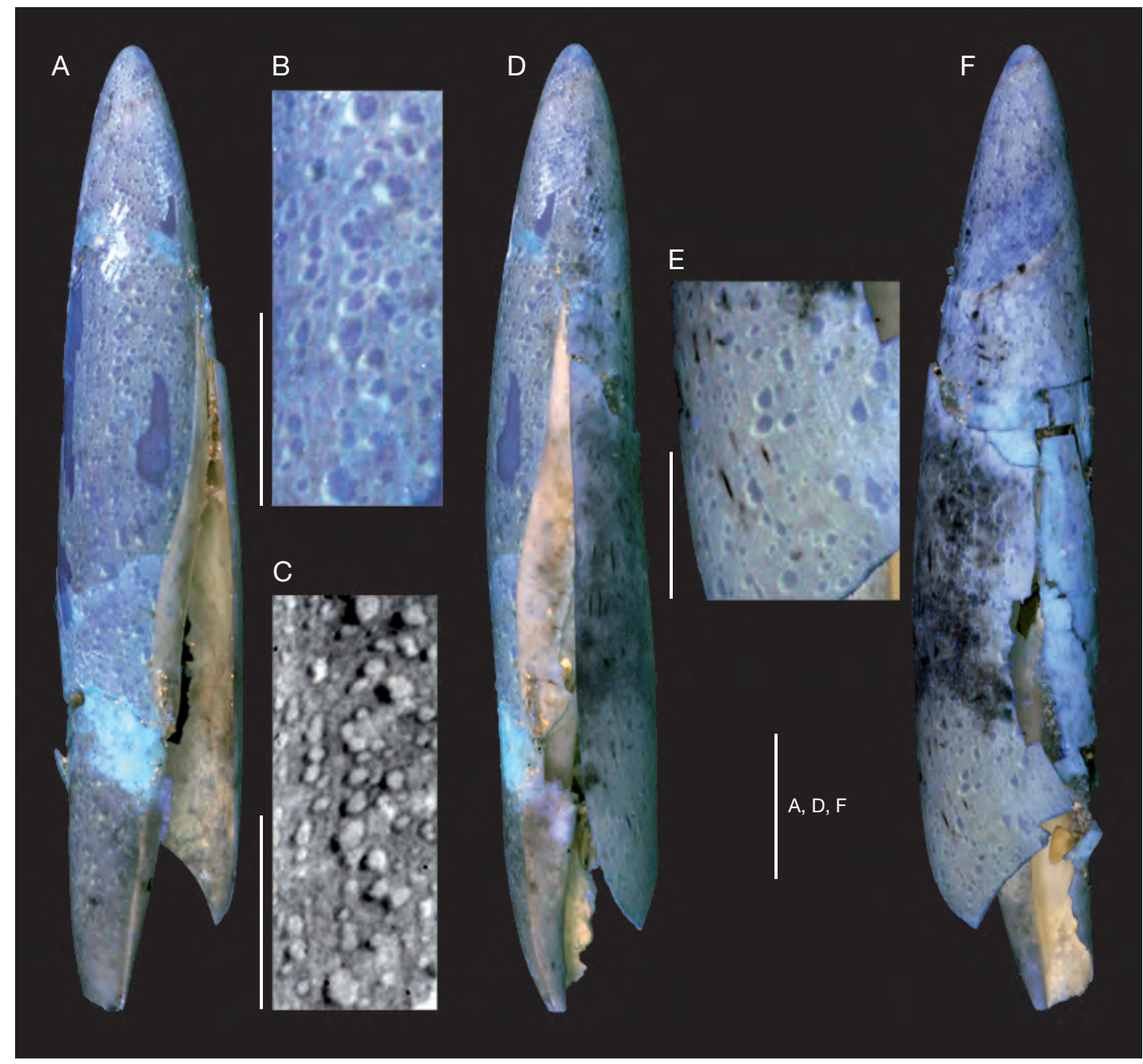

FIG. 30. - Paraseraphs armoricus (Vasseur, 1882) under UV light: A-F, MNHN A28788, Saffré (Bois Gouët), Loire-Atlantique, France, Lutetian; A, ventral view; B, C, detailed views of the dots (C in negative view); D, labral view; E, detailed view of the dots; $\mathbf{F}$, dorsal view). Scale bars: A, D, F, 10 mm; B, C, E, 5 mm. Photographs by C. Lemzaouda (MNHN).

\section{INTRASPECIFIC VARIABILITY:}

Among the species, from examining very numerous samples, a very considerable intraspecific variability observed in Paraseraphs tetanus (304 ex.) and Seraphs chilophorus (160 ex.) is also apparent within the Recent species Terebellum terebellum (Figs 1; 2). However, lower variability is recorded in S. volutatus (494 ex.), D. (M.) isabella (117 ex.) and $P$. placitus (66 ex.). Our study allows an overall view of variability and the distinction of new species, when the sample is sufficient. As a result, a new species $S$. peterjungi n. sp. (24 ex.), has been described and two species are in open nomenclature, because of insufficient specimens (Seraphs sp. 1 and Seraphs sp. 2). The pattern variability appears low for the following species: Seraphs sopitus, S. olivaceus, S. leukoleptus, S. peterjungi n. sp., Diameza (s.s.) fragilis, D. (M.) eratoides and Paraseraphs armoricus, but the number of studied specimens does not exceed 30 (Table 1). 


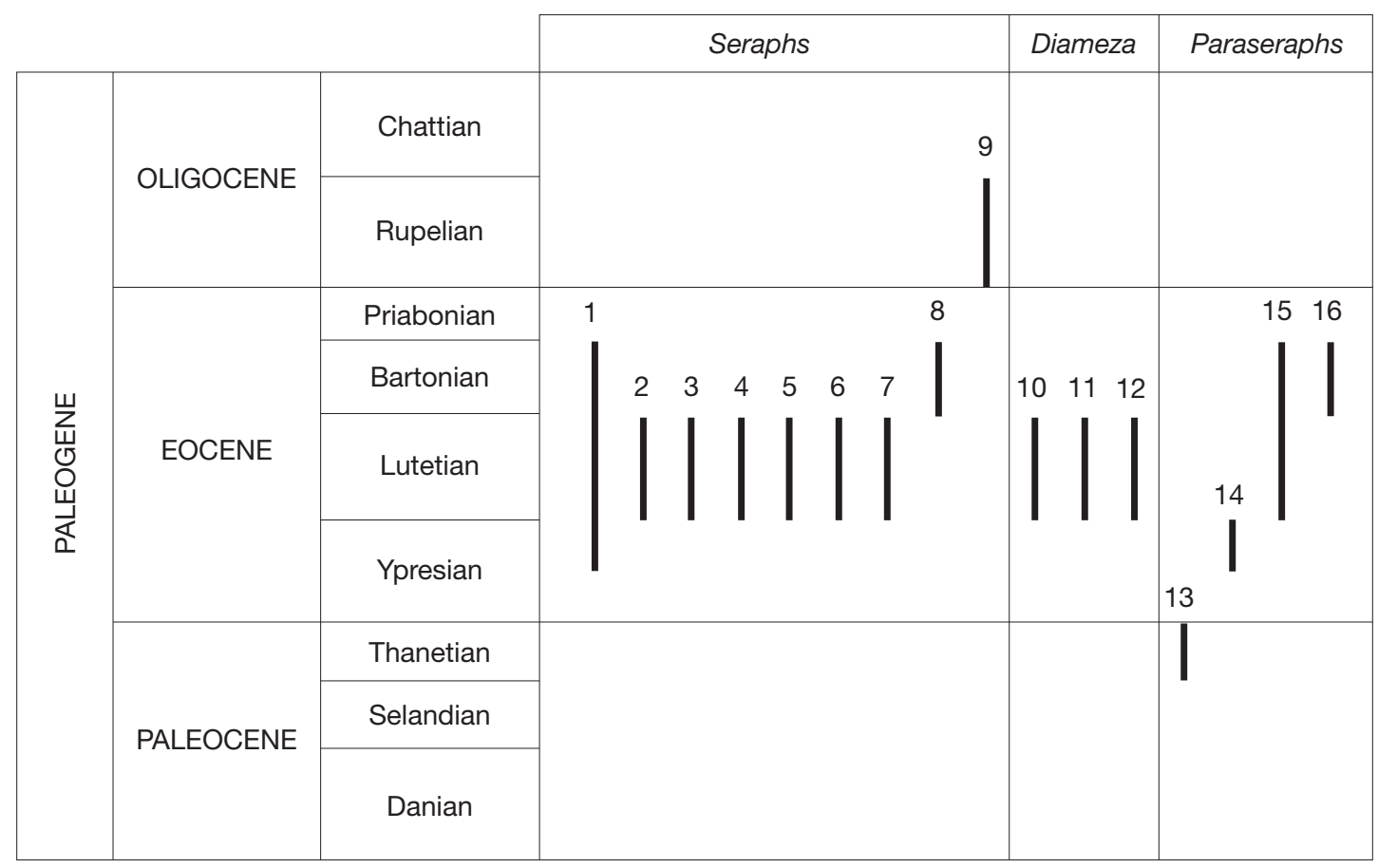

FIG. 31. - New stratigraphic ranges of the Paleogene Seraphsidae Jung, 1974: 1, Seraphs volutatus (Solander in Brander, 1766); 2, Seraphs olivaceus (Cossmann, 1889); 3, Seraphs chilophorus (Cossmann, 1889); 4, Seraphs peterjungi n. sp.; 5, Seraphs leukoleptus Jung, 1974; 6, Seraphs sp. 1; 7, Seraphs sp. 2; 8, Seraphs sopitus (Solander in Brander, 1766); 9, Seraphs subconvolutus (d'Orbigny, 1852); 10, Diameza (s.s.) fragilis (Defrance, 1825); 11, Diameza (Miniseraphs) eratoides (Cossmann, 1889); 12, Diameza (Miniseraphs) isabella (Bernay in Deshayes, 1865); 13, Paraseraphs praecedens n. sp.; 14, Paraseraphs tetanus Jung, 1974; 15, Paraseraphs placitus Jung, 1974; 16, Paraseraphs armoricus (Vasseur, 1882).

\section{SYSTEMATIC RESULTS}

1) Seraphs peterjungi n. sp. is defined on the base of the residual pattern, but it resembles the shell shape of $S$. chilophorus. Accordingly, both species cannot be distinghished without a study under UV light; 2) in previous works, Diameza and Miniseraphs were regarded as two subgenera of Seraphs. The morphologies of the residual pattern, only slightly variable, are very close but strongly differ from those of the members of Seraphs. Considering also the shell morphology, Diameza fragilis, Miniseraphs eratoides and $M$. isabella are excluded from Seraphs. These three species are, here, regarded as belonging to a distinct genus Diameza including two subgenera: Diameza and Miniseraphs. Seraphs no longer includes any subgenera; 3) the use of the residual colour pattern as a taxonomic tool provides a new complex of characters enabling us to validate or to invalidate some previous results. For example, in the genus Paraseraphs, several shell shape characteristics have been proposed by Jung (1974) to differentiate P. tetanus from P. placitus. Although observation of the residual patterns under UV light justifies the definition of two species, Jung's differential characteristics make their distinction more difficult and are probably erroneous.

\section{CONCLUSION}

Dommergues et al. (2006) use a palaeontological approach (shell shape and sculpture) in a study of two Recent and closely related species of the genus Trivia Gray, 1837. They show that the only way to distinguish them without the soft 
parts is by the colour pattern: Trivia monacha (Da Costa, 1778) can be easily recognised by three dark coloured dots, while T. arctica (Pultenay, 1799) lacks them. In their work, in spite of strong analysis of the shell shape variability, they state that the palaeontological approach does not "unmask" the real biodiversity. This work shows how observation under UV light provides a contribution to the identification of different species with morphologically similar forms. Thus, the residual colour pattern should be regarded as an additional feature to consider in the concept of palaeontological species.

In the case of the two European Trivia, the occurrence of the dots in T. monacha is a sufficiently constant pattern to distinguish the species from $T$. arctica. Nevertheless, as seen in the single extant Seraphsidae, Terebellum terebellum, huge intraspecific pattern variability is reported. Thus, in the case of the Seraphsidae, it is not possible to consider differences in remnants of the pigmentation from a small sample as the results of speciation and too small sample does not allow for the avoidance of such pitfalls as the overestimation of the fossil biodiversity. This is precisely the case with S. chilophorus and Paraseraphs tetanus, which display a strong intraspecific variability. In conclusion, we fully agree with Dommergues et al. (2006), that colour pattern should be regarded as an additional feature to consider in the concept of palaeontological species, but, as with other characters, it is necessary to take account of the intraspecific variability.

\section{Acknowledgements}

We are indebted to Daniel Ledon, Didier Aucoin, Alain Cluzaud, Arnaud Leroy, Jacques Mouchart, and Alan J. Morton who kindly gave their material for this study. We thank Isabelle Rouget and Gérard Brusseaux (University of Paris VI), Pierre Lozouet and Virginie Héros (MNHN) and Abel Prieur (University of Lyon 1) for access to the collections. We thank Malcolm Symonds for his useful remarks on the English. Our thanks go also to Allan Beu (GNS Science, New Zealand) and Jean-Louis Dommergues (Université de Bourgogne,
Dijon) for their careful review of the manuscript. The photographs have been taken by Christian Lemzaouda and Philippe Loubry (MNHN). This study was made possible thanks to the research programs Plan Pluri Formation État et structure phylogénétique de la biodiversité actuelle et fossile (Dir. P. Janvier) (subprogram: Atelier de terrain: biodiversité du gisement de la falunière de Grignon, Dir. D. Merle) and Patrimoine géologique (Dir. P. de Wever) (subprogram: Stratotype Lutétien, Dir. D. Merle).

\section{REFERENCES}

Bosatta G., Ferrero M. \& Piccoli G. 1973. - Il genere Terebellum e la sua diffusione nel Paleogene Triveneto. Atti e Memorie dell'Accademia Patavina di Scienze Lettere ed Arti 85 (2): 187-208.

Bory De SainT-Vincent J. B. G. M. 1826. — Tableau encyclopédique et méthodique des 3 règnes de la nature. Vers, Coquilles, Mollusques, Polypiers, Zoophytes, etc., Agasse, Paris: 154-180, explanation of plates 287-390.

Bory de Saint-Vincent J. B. G. M. 1827. - Tableau encyclopédique et méthodique des 3 règnes de la nature. Vers, Coquilles, Mollusques et Polypiers. Tome premier. Agasse, Paris: 154-180 (explanation of plates 287-390).

Bouniol P. 1982. — Lornementation pigmentaire des coquilles de Cerithidés actuels et fossiles (s.l.): Apport de la technique de l'Ultra-Violet. Malacologia 22 (1-2): 313-317.

Cailliaud F. 1856. - Aperçu sur les terrains tertiaires inférieurs des communes de Campbon, Arton, Chéméré et Machecoul, dans le département de la Loire-Inférieure. Bulletin de la Société Géologique de France 2 (13): 36-42.

Cate J. M. 1972. - On the occurrence of the volutid subgenus Eneata. Tulane study in Geology and Paleontology 10 (1): 47-50.

Cox L. R. 1969. - General characteristics of Gastropoda, in MOORE R. C. (ed.), Treatise on Invertebrate Paleontology, Part I, Mollusca 1. Geological Society of America \& University Kansas Press, Lawrence: 84-169.

Cluzaud A. \& Cahuzac B. 2006a. — Révision de deux espèces peu connues de Turbo (Gastropoda) du Tertiaire d'Aquitaine. Première partie - Turbo neuvillei Cossmann \& Peyrot, 1917. Bulletin de la Société linnéenne de Bordeaux tome 140 (ns) 34 (1): 15-39.

Cluzaud A. \& Cahuzac B. 2006b. - Révision de deux espèces peu connues de Turbo (Gastropoda) du Tertiaire d'Aquitaine (suite). Deuxième partie - Turbo subsetosus 
d'Orbigny, 1852. Bulletin de la Société linnéenne de Bordeaux tome 141 (ns) 34 (2): 103-134.

Cossmann M. 1889. - Catalogue illustré des coquilles fossiles de l'Éocène des environs de Paris (4e fascicule). Annales de la Société royale malacologique de Belgique 24: 3-385.

Cossmann M. 1898. - Mollusques éocéniques de la Loire-Inférieure. Tome 1, fasc. III. Bulletin de la Société des Sciences naturelles de l'Ouest de la France, 7 (4): 297-358 (sep. p. 111-172), pls 5-11.

Cossmann M. 1904. - Essais de Paléoconchologie comparée, sixième livraison, Cossmann, Paris, 151 p.

COSSMANn M. 1907 - Mollusques éocèniques de la Loire-Inférieure. Tome 3, fasc. III. Bulletin de la Société de Sciences naturelles de l'Ouest de la France, 2e série, 6 (4): 187-318 (sep. p. 125-208), pls 15-20.

Cossmann M. 1917. - Écène de Bretagne. Faune de Bois-Gouët. Atlas paléontologique Hermann \& Fils, Paris, pls 1-19.

Cossmann M. \& Pissarro G. 1905. - Faune éocènique du Cotentin. Gème article. Bulletin de la Société géologique de Normandie 24: 16-86, pl. 11-19.

COSSMANN M. \& PISSARRO G. 1911. - Iconographie complète des coquilles fossiles de l'Éocène des environs de Paris. Tome 2. Hermann, Paris, pls 26-45.

DEFRANCE F. 1825. - Dictionnaire des sciences naturelles. Tome 37. Levrault, Strasbourg, 557 p.

DEFRANCE F. 1827. - Dictionnaire des sciences naturelles. Tome 48. Levrault, Strasbourg, 572 p.

DESHAYES G.-P. 1835. - Description des coquilles fossiles des environs de Paris. Tome 2. Livraisons 40-45. Levrault, Paris: 495-780, Atlas 2, pls 79-106.

DeshaYes G.-P. 1865. - Description des animaux sans vertèbres découverts dans le bassin de Paris. Tome 3. Livraisons 45-50. Baillère, Paris: 201-668.

Deshayes G.P. \& Milne-Edwards H. 1844. - Histoire naturelle des animaux sans vertèbres, présentant les caractères généraux et particuliers de ces animaux, leur distribution, leurs classes, leurs familles, leurs genres, et la citation des principales espèces qui sy rapportent. Deuxième édition, tome 10 : Histoire des Mollusques, Baillière, Paris, 639 p.

DOCKERY D. T. 1977. - Mollusca of the Moodys Branch Formation, Mississippi. Bulletin of Mississippigeological, economic and topographical survey 120: 1-212.

DOCKERY D. T. 1980. - Color patterns of some Eocene molluscs. Mississippi Geology 1 (1): 3-7.

Dolin L., Dolin C. \& Le Renard J. 1980. - Inventaire systématique des Mollusques de l'Auversien à "Faciès charrié" de Baron (Oise), et remarques paléontologiques. Bulletin d'Information des Géologues du Bassin de Paris 17 (2): 26-48.

Dommergues E., Dommergues J. L. \& Dommergues C. H. 2006. - Deux espèces sous un même masque. Le point de vue paléontologique piégé par les coquillles de deux espèces européennes de Trivia (Mollusca, Gas- tropoda). Revue de Paléobiologie 25 (2): 775-790.

Ducrotay de Blainville H. M. 1827. - Atlas $d u$ manuel de Malacologie et de Conchyliologie Levrault, Paris, pls 1-87.

Ducrotay de Blainville H. M. 1828. - Mollusques, Vers et Zoophytes, in Cuvier F., Dictionnaire des sciences naturelles dans lequel on traite méthodiquement des différents êtres de la nature, considérés soit en eux-mêmes, d'après l'état actuel de nos conoissances, soit relativement à l'utilité qu'en peuvent retirer la médecine, l'agriculture, le commerce et les arts. Suivi d'une biographie des plus célèbres naturalistes. Tome 52. Levrault, Paris, $570 \mathrm{p}$.

FisCHER P. 1884. - Manuel de conchyliologie et de paléontologie conchiliologique, ou histoire naturelle des mollusques vivants et fossiles, Savy, Paris: 609-688.

Glibert M. 1933. - Monographie de la faune malacologique du bruxellien des environs de Bruxelles. Mémoires du Musée royal d'Histoire naturelle de Belgique 53: 1-214, pls 1-11.

GLiberT M. 1938. - Faune malacologique des sables de Wemmel. 2: Gastropodes, Scaphopodes, Céphalopodes. Mémoires du Musée royal d'Histoire naturelle de Belgique 85: 3-190, pls 1-4.

GLiberT M. 1963. — Les Mesogastropoda fossiles du Cénozoïque étranger des collections de l'Institut royal des Sciences naturelles de Belgique. Deuxième partie: Fossaridae à Ficidae (inclus). Mémoires de l'Institut royal des Sciences naturelles de Belgique 2 (73): 1-154.

Grateloup S. DE 1834. - Tableau des coquilles fossiles qu'on rencontre dans les terrains calcaires tertiaires (Faluns) des environs de Dax, dans le département des Landes, 11 e article. Bulletin d'Histoire naturelle de la Société linnéenne de Bordeaux 6 (37): 270-320.

GRaTELOUP S. DE 1846. - Conchyliologie fossile des terrains tertiaires du bassin de l'Adour (environ de Dax). Tome 1. Univalves. Lafargue, Bordeaux, 48 pls.

Gregorio A. De 1880. - Fauna di San Giovanni Ilarione (Parisiano). Parte 1a: Cefalopodi e Gastropodi, Montaina \& C., Palermo, i-xxviii +110 p.

Hoerle S. E. 1976. - The genus Conus (Mollusca: Gastropoda) from the Alum Bluff Group of northwestern Florida. Tulane Studies in Geology and Paleontology 12: 1-32.

Hoerle S. E. \& VOKES E. H. 1978. - A review of the volutid genera Lyria and Falsilyria (Mollusca: Gastropoda) in the Tertiary of the Western Atlantic. Tulane Studies in Geology and Paleontology 14(3): 105-130.

Jung P. 1974. - A revision of the family Seraphsidae (Gastropoda: Strombacea). Paleontographica Americana 8 (47): 5-52.

Jung P. \& Tucker Aвbоtт R. 1967. - The genus Terebellum (Gastropoda: Strombidae). Indo-Pacific Mollusca 1 (7): 445-454.

Kaze T., Fumimasa K., MaAc Aguilar Y., Kurihara Y. \& PANDITA H. 2008. - Reconstruction of color 
markings in Vicarya, a Miocene potamidid gastropod (Mollusca) from SE Asia and Japan. Paleontogical Research 12 (4): 345-353.

Kelley P. H. \& SWANn C. T. 1988. — Functional significance of preserved color patterns of molluscs from the Gosport sand (Eocene) of Alabama. Paleontogy 62(1): 83-87.

KorobKOV I. A. 1955. - Spravocnik i Metodiceskoe Rukovodstvo po treticnym Mollüskam, Brûhonogie [Handbook and guide of Tertiary molluscs, Gastropods], Gostoptehizdat, Moscou, 795 p. (in Russian).

Krueger K. K. 1974. - The use of ultraviolet light in the study of fossil shells. Curator 17(1): 36-49.

LAMARCK J.-B. DE 1798. - Tableau encyclopédique et méthodique des 3 règnes de la nature. 21e partie: Mollusques testacés. Agasse, Paris, pls 287-390 (no explanation).

LAMARCK J.-B. DE 1802. — Suite des Mémoires sur les fossiles des environs de Paris. Annales du Muséum d'Histoire naturelle 1: 383-391.

LAMARCK J.-B. DE 1803. - Suite des Mémoires sur les fossiles des environs de Paris. Annales du Muséum d'Histoire naturelle 2: 217-227.

LAMARCK J.-B. DE 1805. - Suite des Mémoires sur les fossiles des environs de Paris. Annales du Muséum d'Histoire naturelle 6: 214-228, pls 1-4 [pls 43-46].

LAMARCK J.-B. DE 1810. — Suite de la détermination des espèces de Mollusques testacés. Genres Tarrière, Ancillaire et Olive. Annales du Muséum d'Histoire naturelle 16: 300-328.

LAMARCK J.-B. DE 1822. - Histoire naturelle des animaux sans vertèbres, présentant les caractères généraux et particuliers de ces animaux, leur distinction, leurs classes, leurs familles, leurs genres, et la citation des principales espèces qui sy rapportent. Tome 7 et supplément (fossiles). Lamarck, Paris, 711 p.

LAMARCK J.-B. DE 1823. - Recueil de planches des coquilles fossiles des environs de Paris avec deux planches des Lymnées fossiles, et autres coquilles qui les accompagnent, des environs de Paris par M. Brard. Dufour \& d'Ocagne, Paris, 30 pls.

Le Renard J. 1992. - Notes de nomenclature sur quelques Mollusques caractéristiques de l'Éocène du Bassin de Paris. Cossmanniana 1 (2-4): 1-14.

LE RENARD J. 2001. - Les espèces éocènes décrites par Defrance dans le Dictionnaire des Sciences Naturelles (1816-1829). Cossmanniana 8 (2-4): 1-40, pls 1-5.

Le Renard J. \& Pacaud J.-M. 1995. — Révision des Mollusques paléogènes du Bassin de Paris. 2: Liste des références primaires des espèces. Cossmanniana 3 (3): 65-132.

LOWRY J. W., ETHERIDGE R. \& EdWARdS F. E. 1866. Figures of the Characteristic British Tertiary Fossils (Chiefly Mollusca) Stratigraphically Arranged. Tennant, London, 4 pls.

MAGNE A. 1940. — Sur quelques espèces intéressantes ou nouvelles provenant du Calcaire à Astéries de la Souys. Procès verbal de la Société linnéenne de Bordeaux 91: 28-36.

MAYER K. 1866. - Catalogue systématique et descriptif des mollusques tertiaires du Musée Fédéral de Zurich. 1. Chénopides, Strombides et Ficulides. Vierteljahrsschrift der Naturforschende Gesellschaft in Zürich 11: 301-337.

MeInHARDT H. 1998. - The Algorithmic beauty of Sea shells. The Virtual Laboratory. Springer-Verlag, Berlin; Heidelberg, New-York, 236 p.

Merle D. 1986. - Contribution à l'étude paléontologique du gisement de Gan (Pyrénées-Atlantiques): Systématique, évolution et paléoécologie. Diplôme de l'E.P.H.E, Dijon, $394 \mathrm{p}$.

Merle D. 2003. - First record of coloured patterns in Palaeogene Muricidae (Mollusca, Gastropoda). Annales de Paléontologie 89: 191-203.

Merle D., Pacaud J.-M., Kriloff A. \& Loubry P. 2008. - Les motifs colorés résiduels des coquilles lutétiennes du Bassin de Paris, in Merle D. (ed.), Stratotype lutétien. Collection Patrimoine géologique 1. Muséum national d'Histoire naturelle, Paris; Biotope, Mèze; BRGM, Orléans: 182-227, pls 18-35.

MONTFORT D. DE 1810. - Conchyliologie systématique, et classification méthodique des coquilles offrant leurs figures, leur arrangement générique, leurs descriptions caractéristiques, leurs noms, ainsi que leur synonymie en plusieurs langues. Tome second: coquilles univalves, non cloisonnées. Schoell, Paris, 676 p.

NewTON R. B. 1894. - Systematic list of the Frederick E. Edwards collection of British oligocene and eocene mollusca in the British Museum (Natural History) with references to the type-specimens from similar horizons contained in other collections belonging to the geological department of the Museum. British Museum (Natural History), London, $365 \mathrm{p}$.

Oppenheim P. 1896. - Die Eocaenfauna des Monte Postale bei Bolca im Veronesischen. Palaeontographica 43: 125-221.

OrbignY A. D' 1850. — Prodrome de paléontologie stratigraphique universelle des animaux mollusques et rayonnés. Volume 2. Masson, Paris, 428 p.

OrbigNy A. D' 1852. - Prodrome de Paléontologie stratigraphique universelle des animaux mollusques et rayonnés et table alphabétique et synonymique des genres et des espèces contenus dans le Prodrome de Paléontologie stratigraphique universelle. Volume 3. Masson, Paris, $196+191 \mathrm{p}$.

Pacaud J.-M. \& Le Renard J. 1995. - Révision des Mollusques paléogènes du Bassin de Paris. 4 - Liste systématique actualisée. Cossmanniana 3 (4): 151-187.

PaCAud J.-M. 2003. - First fossil records of the Recent Ovulid genus Pseudocypraea Schilder, 1927 (Mollusca: Gastropoda) with description of a new species. Geodiversitas 25 (3): 451-462. 
PACAUD J.-M. 2007. — Nouveautés nomenclaturales et taxonomiques introduites par Alcide d'Orbigny dans le Prodrome $(1850,1852)$ pour les espèces du Paléocène et de l'Éocène. Geodiversitas 29 (1): 17-86.

PACAUD J.-M. 2008. - Terebellomimus quaggiottoi n. gen., n. sp. (Mollusca, Gastropoda, Littorinimorpha, Rostellariidae) du Lutétien inférieur (Éocène moyen) du Vicentin (Italie). Geodiversitas 30 (4): 721-729.

Palmer K. van WINKLE 1977. - The unpublished Vélins of Lamarck (1802-1809). Illustrations of fossils of the Paris Basin Eocene. Paleontological Research Institution, Ithaca, $67 \mathrm{p}$.

PICTET F. J. 1855. - Traité de paléontologie ou histoire naturelle des animaux fossiles considérés dans leurs rapports zoologiques et géologiques. Volume 3. Baillière, Paris, 654 p., 110 pls.

Piтt W. D. \& PitT L. J. 1992. — Naticidae (Mollusca: Gastropoda) from the Neogene of northwestern Ecuador. Tulane Studies in Geology and Paleontology 25 (4): 109-138.

PitT W. D. \& PITT L. J. 1993. — Ultra-violet light as a useful tool for identifying fossil molluscs, with examples from the Gatun formation, Panama. Tulane Studies in Geology and Paleontology 26 (1): 1-13.

RoISSY F. DE 1804. - Histoire naturelle, générale et particulière, des mollusques, animaux sans vertèbres et à sang blanc faisant suite aux ouvres de Leclerc de Buffon, et partie du cours rédigé par C. S. Sonnini. Dufart, Paris, tome 5, $451 \mathrm{p}$.

SAVAZZI E. 1991. - Constructional morphology of strombid gastropods. Lethaia 24 (3): 311-331.

Solander D. C. 1766. - Descriptiones Specierum, in
Brander G. (ed.), Fossilia Hantoniensia collecta, et in Musaeo Brittannico deposita. London: 9-43.

SOWERBY J. 1821. - The Mineral Conchology of Great Britain; or Coloured Figures and Descriptions of those Remains of Testaceous Animals or Shells which have been Preserved at Various Times and Dephts in the Earth. Arding \& Merrett, London, Vol. 3, pls 272-318.

SWANN C. T. \& Kelley P. H. 1985. - Residual colour patterns in Molluscs from the Gosport sand (Eocene), Alabama. Mississippi Geology 5 (3): 1-8.

VASSEUR G. 1881. - Recherches géologiques sur les Terrains tertiaires de la France occidentale. Stratigraphie. Annales des Sciences géologiques 13: 1-432.

VASSEUR G. 1882. - Recherches géologiques sur les Terrains tertiaires de la France occidentale. Paléontologie, Atlas, Quinsac, Toulouse, pls 1-3 et 5-11. The plates 4 and 19 have been published with their explanation in 1881 (see Vasseur 1881: 421, nota).

VERGNEAU A. M. 1967. — Les gisements de l'Oligocène marin en Aquitaine. Bulletin de l'Institut de Géologie Bassin d'Aquitaine 3: 191-208.

VOKES H. E. \& VOKES E. H. 1968. - Variation in the genus Orthaulax (Mollusca: Gastropoda). Tulane study in Geology and Paleontology 6 (2): 71-79.

WeNZ W. 1940. — Handbuch der Paläozoologie, Gastropoda, vol. 6. Teil I: Allgemeiner Teil und Prosobranchia, Borntraeger, Berlin: 721-960.

WiLSON E. C. 1975. — Light show from beyond the grave. Terra 13 (3): 10-13.

WOOD W. 1829. - Fossilia Hantoniensia or Hampshire fossiles, collected, and in the British Museum deposited, by Gustavus Brander. Wood, London, 16 p. 


\section{APPENDIX 1}

List of the fossil material. Abbreviations: no, no collection number; $\mathbf{x}$, inadequate preservation, UV test useless. All the numbered specimens are deposited at the MNHN except the specimen EM 33124.

\begin{tabular}{|c|c|c|c|c|c|}
\hline $\begin{array}{l}\text { Registration } \\
\text { number }\end{array}$ & Collection & $\begin{array}{c}\text { Num } \\
\text { of } \\
\text { spec }\end{array}$ & Locality & Stage & $\begin{array}{c}\text { Positive } \\
\text { under UV } \\
\text { light }\end{array}$ \\
\hline \multicolumn{6}{|c|}{ Seraphs volutatus (Solander in Brander, 1766) } \\
\hline \multicolumn{6}{|c|}{ Ypresian, Paris Basin } \\
\hline A30419 & Leroy & 1 & Sapicourt, Marne, France & Ypresian & 1 \\
\hline A30420 & Leroy & 1 & Sapicourt, Marne, France & Ypresian & 1 \\
\hline \multicolumn{6}{|c|}{ Lutetian, Paris Basin } \\
\hline B71552 & Museum & 4 & Beynes, Yvelines, France & Lutetian & 4 \\
\hline A11189 & d'Orbigny & 4 & Blaye, Gironde, France & Lutetian & $\mathrm{x}$ \\
\hline A27554 & Galerie de Zoologie & 4 & Boursault, Marne, France & Lutetian & 3 \\
\hline B63228 & Museum & 4 & Chambors, Oise, France & Lutetian & 4 \\
\hline B63234 & Museum & 1 & Chamery, Marne, France & Lutetian & 1 \\
\hline A28878 & Museum & 3 & Chaussy, Val-d'Oise, France & Lutetian & 3 \\
\hline A27560 & Morlet & 1 & Chaussy, Val-d'Oise, France & Lutetian & 1 \\
\hline A27577 & Faullummel & 12 & Chaussy, Val-d'Oise, France & Lutetian & 11 \\
\hline A28516 & Pacaud & 1 & Chaussy, Val-d'Oise, France & Lutetian & 0 \\
\hline A28539 & Faullummel & 2 & Chaussy, Val-d'Oise, France & Lutetian & 2 \\
\hline A28541 & Schtrock & 1 & Chaussy, Val-d'Oise, France & Lutetian & 0 \\
\hline A25577 & Museum & 12 & Chaussy, Val-d'Oise, France & Lutetian & 12 \\
\hline B70329 & Morlet & 2 & Chaussy, Val-d'Oise, France & Lutetian & 2 \\
\hline A28548 & Lhomme & 1 & Chaussy, Val-d'Oise, France & Lutetian & 1 \\
\hline A28549 & Pacaud & 6 & Chaussy, Val-d'Oise, France & Lutetian & 4 \\
\hline A28555 & Pacaud & 3 & Chaussy, Val-d'Oise, France & Lutetian & 3 \\
\hline A27681 & Mouchart & 26 & Cressay, Yvelines, France & Lutetian & 24 \\
\hline A27567 & Pacaud & 1 & Cressay, Yvelines, France & Lutetian & 1 \\
\hline B63233 & Lhomme & 1 & Damery, Marne, France & Lutetian & 1 \\
\hline A27540 & Galerie de Zoologie & 19 & Ferme de l'Orme, Yvelines, France & Lutetian & 16 \\
\hline B70327 & Morlet & 6 & Ferme de l'Orme, Yvelines, France & Lutetian & 6 \\
\hline B63223 & Museum & 10 & Ferme de l'Orme, Yvelines, France & Lutetian & 10 \\
\hline B63249 & Museum & 16 & Ferme de l'Orme, Yvelines, France & Lutetian & 14 \\
\hline A27589 & Pacaud & 2 & Ferme de l'Orme, Yvelines, France & Lutetian & 2 \\
\hline B63222 & Museum & 3 & Ferme de l'Orme, Yvelines, France & Lutetian & 3 \\
\hline B63224 & Lhomme & 3 & Ferme de l'Orme, Yvelines, France & Lutetian & 2 \\
\hline A27562 & Museum & 15 & Ferme de l'Orme, Yvelines, France & Lutetian & 13 \\
\hline A28886 & Valenciennes & 1 & Fontenay-en-Vexin, Eure, France & Lutetian & 1 \\
\hline A27609 & Valenciennes & 21 & Fontenay-en-Vexin, Eure, France & Lutetian & 21 \\
\hline A27614 & Pacaud & 1 & Fontenay-en-Vexin, Eure, France & Lutetian & 1 \\
\hline A28875 & Valenciennes & 1 & Fontenay-en-Vexin, Eure, France & Lutetian & 1 \\
\hline B63238 & de Morgan & 35 & Fresville, Manche, France & Lutetian & 23 \\
\hline A28794 & Museum & 9 & Gentilly, Val-de-Marne, France & Lutetian & $\mathrm{x}$ \\
\hline B63218 & Lhomme & 3 & Grignon, Yvelines, France & Lutetian & 3 \\
\hline A27548 & Watelet & 4 & Grignon, Yvelines, France & Lutetian & 3 \\
\hline B63220 & Museum & 21 & Grignon, Yvelines, France & Lutetian & 19 \\
\hline A27682 & Schtrock & 1 & Grignon, Yvelines, France & Lutetian & $\mathrm{x}$ \\
\hline A28568 & Museum & 1 & Grignon, Yvelines, France & Lutetian & 1 \\
\hline A28573 & Museum & 3 & Grignon, Yvelines, France & Lutetian & 3 \\
\hline A28574 & Museum & 2 & Grignon, Yvelines, France & Lutetian & 2 \\
\hline A28575 & Museum & 3 & Grignon, Yvelines, France & Lutetian & 3 \\
\hline A28576 & Museum & 26 & Grignon, Yvelines, France & Lutetian & 26 \\
\hline A28776 & Galerie de Zoologie & 1 & Grignon, Yvelines, France & Lutetian & 1 \\
\hline B70325 & Lamarck & 1 & Grignon, Yvelines, France & Lutetian & 1 \\
\hline A28775 & Lamarck & 2 & Grignon, Yvelines, France & Lutetian & 2 \\
\hline A28873 & Museum & 1 & Grignon, Yvelines, France & Lutetian & 1 \\
\hline
\end{tabular}


APPENDIX 1 - Continuation.

\begin{tabular}{|c|c|c|c|c|c|}
\hline $\begin{array}{l}\text { Registration } \\
\text { number }\end{array}$ & Collection & $\begin{array}{l}\text { Num. } \\
\text { of } \\
\text { spec. }\end{array}$ & Locality & Stage & $\begin{array}{l}\text { Positive } \\
\text { under UV } \\
\text { light }\end{array}$ \\
\hline $\mathrm{A} 28874$ & Museum & 1 & Grignon, Yvelines, France & Lutetian & 1 \\
\hline A28569 & Museum & 1 & Grignon, Yvelines, France & Lutetian & 1 \\
\hline B63219 & Morlet & 1 & Grignon, Yvelines, France & Lutetian & 1 \\
\hline A28514 & Museum & 21 & Grignon, Yvelines, France & Lutetian & 21 \\
\hline A28524 & Pacaud & 3 & Grignon, Yvelines, France & Lutetian & 3 \\
\hline A28528 & Ballot & 6 & Grignon, Yvelines, France & Lutetian & 6 \\
\hline A28535 & Schtrock & 1 & Grignon, Yvelines, France & Lutetian & 1 \\
\hline A27633 & Galerie de Zoologie & 26 & Grignon, Yvelines, France & Lutetian & 23 \\
\hline A28542 & Museum & 6 & Grignon, Yvelines, France & Lutetian & 6 \\
\hline $\mathrm{B} 63221$ & Museum & 5 & Grignon, Yvelines, France & Lutetian & 5 \\
\hline A27520 & Hoffstetter & 1 & Grignon, Yvelines, France & Lutetian & 1 \\
\hline A27679 & Brongniart & 8 & Grignon, Yvelines, France & Lutetian & 8 \\
\hline A27556 & Museum & 13 & Grignon, Yvelines, France & Lutetian & 13 \\
\hline A27516 & Margerie & 3 & Grignon, Yvelines, France & Lutetian & 3 \\
\hline $\mathrm{A} 27557$ & Saint-Marceau & 4 & Hermonville, Marne, France & Lutetian & $x$ \\
\hline A11188 & d'Orbigny & 2 & Hermonville, Marne, France & Lutetian & $x$ \\
\hline A27592 & Galerie de Zoologie & 4 & Hermonville, Marne, France & Lutetian & 4 \\
\hline $\mathrm{B} 63230$ & Morlet & 1 & Latainville, Oise, France & Lutetian & 1 \\
\hline B63232 & Lhomme & 1 & Montainville, Yvelines, France & Lutetian & 1 \\
\hline $\mathrm{B} 63246$ & Lhomme & 2 & Montchauvet, Yvelines, France & Lutetian & 2 \\
\hline B63246 & Museum & 2 & Montchauvet, Yvelines, France & Lutetian & 2 \\
\hline A27630 & Galerie de Zoologie & 8 & Mouchy-le-Châtel, Oise, France & Lutetian & 8 \\
\hline A27598 & Roissy & 12 & Parnes, Oise, France & Lutetian & 10 \\
\hline $\mathrm{B} 63210$ & Museum & 1 & Parnes, Oise, France & Lutetian & 1 \\
\hline A28515 & Roissy & 1 & Parnes, Oise, France & Lutetian & 1 \\
\hline A28532 & Museum & 2 & Parnes, Oise, France & Lutetian & 2 \\
\hline $\mathrm{B} 63217$ & Museum & 1 & Parnes, Oise, France & Lutetian & 1 \\
\hline B70328 & d'Orbigny & 7 & Parnes, Oise, France & Lutetian & 7 \\
\hline A27545 & Bernay & 2 & Parnes, Oise, France & Lutetian & 2 \\
\hline B71553 & Museum & 2 & Parnes, Oise, France & Lutetian & 2 \\
\hline B63214 & de Morgan & 1 & Parnes, Oise, France & Lutetian & 1 \\
\hline A27565 & Pacaud & 1 & Parnes, Oise, France & Lutetian & 1 \\
\hline B63216 & Museum & 3 & Parnes, Oise, France & Lutetian & $x$ \\
\hline B70328 & d'Orbigny & 7 & Parnes, Oise, France & Lutetian & 7 \\
\hline A28793 & Roissy & 2 & Parnes, Oise, France & Lutetian & $x$ \\
\hline A27588 & Pacaud & 5 & St-Lubin-de-la-Haye, Eure-et-Loir, France & Lutetian & 4 \\
\hline A27586 & Pacaud & 1 & St-Lubin-de-la-Haye, Eure-et-Loir, France & Lutetian & 1 \\
\hline A27586 & Museum & 1 & St-Lubin-de-la-Haye, Eure-et-Loir, France & Lutetian & 0 \\
\hline A11187 & Galerie de Zoologie & 3 & St-Thomas, Aisne, France & Lutetian & $x$ \\
\hline A27680 & Brongniart & 1 & Septeuil, Yvelines, France & Lutetian & 1 \\
\hline A28518 & Bertrant & 19 & Thiverval, Yvelines, France & Lutetian & 17 \\
\hline B70326 & Morlet & 3 & Thury-en-Valois, Oise, France & Lutetian & 3 \\
\hline B63226 & Museum & 1 & Ully-Saint-Georges, Oise, France & Lutetian & 1 \\
\hline $\mathrm{A} 27546$ & Galerie de Zoologie & 2 & Vaudancourt, Oise, France & Lutetian & $x$ \\
\hline $\mathrm{A} 27578$ & Faullummel & 6 & Venteuil-Arty, Marne, France & Lutetian & 6 \\
\hline $\mathrm{A} 27517$ & Margerie & 9 & Villiers-St-Frédéric, Yvelines, France & Lutetian & 9 \\
\hline A27515 & Braillon & 7 & Villiers-St-Frédéric, Yvelines, France & Lutetian & 7 \\
\hline J09265 & Cossmann & 11 & Villiers-St-Frédéric, Yvelines, France & Lutetian & 11 \\
\hline B63225 & Museum & 3 & Villiers-St-Frédéric, Yvelines, France & Lutetian & 3 \\
\hline $\mathrm{A} 05708$ & Pacaud & 9 & Villiers-St-Frédéric, Yvelines, France & Lutetian & 9 \\
\hline IM 665 & Houdas & 6 & Villiers-St-Frédéric, Yvelines, France & Lutetian & 6 \\
\hline \multicolumn{6}{|c|}{ Lutetian, Cotentin } \\
\hline A28877 & Pacaud & 7 & Hauteville-Bocage, Manche, France & Lutetian & $x$ \\
\hline A27584 & Pacaud & 6 & Hauteville-Bocage, Manche, France & Lutetian & 4 \\
\hline
\end{tabular}


APPENDIX 1 - Continuation.

\begin{tabular}{|c|c|c|c|c|c|}
\hline $\begin{array}{l}\text { Registration } \\
\text { number }\end{array}$ & Collection & $\begin{array}{c}\text { Num. } \\
\text { of } \\
\text { spec. }\end{array}$ & Locality & Stage & $\begin{array}{c}\text { Positive } \\
\text { under UV } \\
\text { light }\end{array}$ \\
\hline \multicolumn{6}{|l|}{ Lutetian, Italy } \\
\hline A27538 & Galerie de Zoologie & 1 & Val Ciupio, Italy & Lutetian & $\mathrm{x}$ \\
\hline \multicolumn{6}{|c|}{ Bartonian, Paris Basin } \\
\hline A28791 & Galerie de Zoologie & 4 & Acy-en-Multien, Oise, France & Bartonian & $\mathrm{x}$ \\
\hline A28570 & Museum & 1 & Caumont, Seine-et-Marne, France & Bartonian & 1 \\
\hline A28879 & Faullummel & 3 & Luzancy, Seine-et-Marne, France & Bartonian & 2 \\
\hline A28583 & Faullummel & 2 & Mary-sur-Marne, Seine-et-Marne, France & Bartonian & 2 \\
\hline A27523 & Pacaud & 1 & Ronquerolles, Val-d'Oise, France & Bartonian & $x$ \\
\hline B63235 & $1965-11$ & 2 & Verneuil, Marne, France & Bartonian & 1 \\
\hline \multicolumn{6}{|c|}{ Bartonian, Loire-Atlantique } \\
\hline A27529 & Pacaud & 10 & Bois-Gouët, Loire-Atlantique, France & Bartonian & 3 \\
\hline \multicolumn{6}{|c|}{ Seraphs sopitus (Solander in Brander, 1766) } \\
\hline \multicolumn{6}{|c|}{ Bartonian, Paris Basin } \\
\hline A28881 & Faullummel & 2 & Baron, Oise, France & Bartonian & 1 \\
\hline A28883 & Faullummel & 1 & Le Guépelle, Val-d'Oise, France & Bartonian & 0 \\
\hline A27526 & Pacaud & 1 & Le Guépelle, Val-d'Oise, France & Bartonian & 1 \\
\hline A28884 & Pacaud & 1 & Le Guépelle, Val-d'Oise, France & Bartonian & 1 \\
\hline A28880 & Faullummel & 1 & Le Limon, Seine-et-Marne, France & Bartonian & 1 \\
\hline A28778 & Faullummel & 1 & Le Limon, Seine-et-Marne, France & Bartonian & 1 \\
\hline A27524 & Pacaud & 6 & Le Quoniam, Val-d'Oise, France & Bartonian & 5 \\
\hline A28882 & Faullummel & 1 & Vendrest, Seine-et-Marne, France & Bartonian & 0 \\
\hline \multicolumn{6}{|c|}{ Bartonian, England } \\
\hline B45405 & & 1 & Barton-on-sea, Hampshire, UK & Bartonian & 1 \\
\hline no & Morton & 12 & Barton-on-sea, Hampshire, UK & Bartonian & 0 \\
\hline \multicolumn{6}{|c|}{ Seraphs olivaceus (Cossmann, 1889) } \\
\hline \multicolumn{6}{|c|}{ Lutetian, Paris Basin } \\
\hline A28526 & Ledon & 3 & Chaussy, Val-d'Oise, France & Lutetian & 3 \\
\hline A27582 & Faullummel & 2 & Chaussy, Val-d'Oise, France & Lutetian & 2 \\
\hline A27552 & Schtrock & 1 & Chaussy, Val-d'Oise, France & Lutetian & 0 \\
\hline A27591 & Houdas & 1 & Chaussy, Val-d'Oise, France & Lutetian & 1 \\
\hline A28577 & Ledon & 1 & Chaussy, Val-d'Oise, France & Lutetian & 1 \\
\hline A28885 & Pacaud & 1 & Chaussy, Val-d'Oise, France & Lutetian & 1 \\
\hline A29225 & Ledon & 1 & Chaussy, Val-d'Oise, France & Lutetian & 1 \\
\hline A28560 & Pacaud & 1 & Chaussy, Val-d'Oise, France & Lutetian & 1 \\
\hline A29057 & Houdas & 1 & Chaussy, Val-d'Oise, France & Lutetian & 1 \\
\hline A27593 & Pacaud & 4 & Fercourt, Oise, France & Lutetian & 4 \\
\hline A27608 & Valenciennes & 3 & Fontenay-en-Vexin, Eure, France & Lutetian & 2 \\
\hline A27631 & Galerie de Zoologie & 1 & Mouchy-le-Châtel, Oise, France & Lutetian & 1 \\
\hline A28546 & Pacaud & 1 & Parnes, Oise, France & Lutetian & 1 \\
\hline B63839 & Morlet & 1 & Parnes, Oise, France & Lutetian & 1 \\
\hline \multicolumn{6}{|c|}{ Seraphs sp. 1} \\
\hline \multicolumn{6}{|c|}{ Lutetian, Paris Basin } \\
\hline A25011 & Faullummel & 1 & Chaussy, Val-d'Oise, France & Lutetian & 1 \\
\hline A28547 & Museum & 1 & Parnes, Oise, France & Lutetian & 1 \\
\hline \multicolumn{6}{|l|}{ Seraphs sp. 2} \\
\hline \multicolumn{6}{|c|}{ Lutetian, Cotentin } \\
\hline A28887 & de Morgan & 1 & Fresville, Manche, France & Lutetian & 1 \\
\hline \multicolumn{6}{|c|}{ Seraphs leukoleptus Jung, 1974} \\
\hline \multicolumn{6}{|c|}{ Lutetian, Paris Basin } \\
\hline IM 923 & Houdas & 1 & Chaussy, Val-d'Oise, France & Lutetian & 1 \\
\hline A27551 & Schtrock & 1 & Chaussy, Val-d'Oise, France & Lutetian & 0 \\
\hline A28527 & Ledon & 1 & Chaussy, Val-d'Oise, France & Lutetian & 1 \\
\hline
\end{tabular}


APPENDIX 1 - Continuation.

\begin{tabular}{|c|c|c|c|c|c|}
\hline $\begin{array}{l}\text { Registration } \\
\text { number }\end{array}$ & Collection & $\begin{array}{l}\text { Num. } \\
\text { of } \\
\text { spec. }\end{array}$ & Locality & Stage & $\begin{array}{l}\text { Positive } \\
\text { under UV } \\
\text { light }\end{array}$ \\
\hline A28781 & Ledon & 1 & Chaussy, Val-d'Oise, France & Lutetian & 1 \\
\hline A28968 & Houdas & 1 & Chaussy, Val-d'Oise, France & Lutetian & 1 \\
\hline \multicolumn{6}{|c|}{ Seraphs subconvolutus (d'Orbigny, 1852) } \\
\hline \multicolumn{6}{|c|}{ Rupelian, Aquitan Basin } \\
\hline no & Cluzaud & 1 & Gaas (Lagouarde), Landes, France & Rupelian & 0 \\
\hline no & Aucoin & 2 & Gaas (Lagouarde), Landes, France & Rupelian & 0 \\
\hline no & Cluzaud & 8 & Gaas (Espibos), Landes, France & Rupelian & 0 \\
\hline no & Aucoin & 2 & Gaas (Espibos), Landes, France & Rupelian & 0 \\
\hline A28967 & Aucoin & 1 & Gaas (Espibos), Landes, France & Rupelian & 0 \\
\hline
\end{tabular}

Seraphs chilophorus (Cossmann, 1889)

Lutetian, Paris Basin

$\begin{array}{ll}\text { B63229 } & \text { Morlet } \\ \text { A28505 } & \text { Morlet } \\ \text { A28510 } & \text { Museum } \\ \text { A28536 } & \text { Faullummel } \\ \text { A28540 } & \text { Faullummel } \\ \text { A27558 } & \text { Morlet } \\ \text { A27585 } & \text { Pacaud } \\ \text { B63242 } & \text { Lhomme } \\ \text { A28551 } & \text { Pacaud } \\ \text { A28557 } & \text { Pacaud } \\ \text { A28558 } & \text { Ledon } \\ \text { A27595 } & \text { Faullummel } \\ \text { A28779 } & \text { Ledon } \\ \text { A28509 } & \text { Pacaud } \\ \text { A27612 } & \text { Pacaud } \\ \text { A28922 } & \text { Pacaud } \\ \text { A28923 } & \text { Pacaud } \\ \text { A28924 } & \text { Pacaud } \\ \text { A28925 } & \text { Pacaud } \\ \text { A28926 } & \text { Pacaud } \\ \text { A27610 } & \text { Pacaud } \\ \text { A25009 } & \text { Museum } \\ \text { A27596 } & \text { Galerie de Zoologie } \\ \text { A28513 } & \text { Caze } \\ \text { A28529 } & \text { Ballot } \\ \text { A28534 } & \text { Museum } \\ \text { A28543 } & \text { Museum } \\ \text { B63213 } & \text { Museum } \\ \text { A27600 } & \text { Roissy } \\ \text { A27583 } & \text { Pacaud } \\ \text { A27601 } & \text { Galerie de Zoologie } \\ \text { A28565 } & \text { Morlet } \\ \text { A28581 } & \text { d'Orbigny } \\ \text { A28790 } & \text { d'Orbigny } \\ \text { A28927 } & \text { Roissy } \\ \text { A28928 } & \text { Pacaud } \\ \text { A28889 } & \text { Pacaud } \\ \text { A28888 } & \text { Pacaud } \\ \text { A28890 } & \text { Pacaud } \\ \text { A28891 } & \\ \text { A28919 } 28920 & \text { Pacaud } \\ \text { A28929 } & \end{array}$

Châteaurouge, Oise, France 4 Chaussy, Val-d'Oise, France 5 Chaussy, Val-d'Oise, France 2 Chaussy, Val-d'Oise, France 3 Chaussy, Val-d'Oise, France 3 Chaussy, Val-d'Oise, France 1 Chaussy, Val-d'Oise, France 2 Chaussy, Val-d'Oise, France 17 Chaussy, Val-d'Oise, France 12 Chaussy, Val-d'Oise, France 8 Chaussy, Val-d'Oise, France 4 Chaussy, Val-d'Oise, France 1 Chaussy, Val-d'Oise, France 1 Fercourt, Oise, France

16 Fercourt, Oise, France 1 Fercourt, Oise, France

1 Fercourt, Oise, France

1 Fercourt, Oise, France

1 Fercourt, Oise, France

1 Fercourt, Oise, France

1 Fontenay-en-Vexin, Eure, France

1 Fontenay-en-Vexin, Eure, France

1 Grignon, Yvelines, France

1 Grignon, Yvelines, France

1 Grignon, Yvelines, France

1 Grignon, Yvelines, France

1 Grignon, Yvelines, France

1 Parnes, Oise, France

3 Parnes, Oise, France

32 Parnes, Oise, France

1 Parnes, Oise, France

1 Parnes, Oise, France

1 Parnes, Oise, France

1 Parnes, Oise, France

1 Parnes, Oise, France

1 Parnes, Oise, France

1 Parnes, Oise, France

1 Parnes, Oise, France

1 Parnes, Oise, France

1 Parnes, Oise, France

1 Parnes, Oise, France

1 Parnes, Oise, France

1 Parnes, Oise, France

$\begin{array}{lr}\text { Lutetian } & 1 \\ \text { Lutetian } & 4 \\ \text { Lutetian } & 5 \\ \text { Lutetian } & 2 \\ \text { Lutetian } & 3 \\ \text { Lutetian } & 3 \\ \text { Lutetian } & 1 \\ \text { Lutetian } & 2 \\ \text { Lutetian } & 17 \\ \text { Lutetian } & 12 \\ \text { Lutetian } & 8 \\ \text { Lutetian } & 4 \\ \text { Lutetian } & 1 \\ \text { Lutetian } & 1 \\ \text { Lutetian } & 15 \\ \text { Lutetian } & 1 \\ \text { Lutetian } & 1 \\ \text { Lutetian } & 1 \\ \text { Lutetian } & 1 \\ \text { Lutetian } & 1 \\ \text { Lutetian } & 1 \\ \text { Lutetian } & 1 \\ \text { Lutetian } & 1 \\ \text { Lutetian } & 1 \\ \text { Lutetian } & 1 \\ \text { Lutetian } & 1 \\ \text { Lutetian } & 1 \\ \text { Lutetian } & 1 \\ \text { Lutetian } & 3 \\ \text { Lutetian } & 32 \\ \text { Lutetian } & 0 \\ \text { Lutetian } & 1 \\ \text { Lutetian } & 1 \\ \text { Lutetian } & 1 \\ \text { Lutetian } & 1 \\ \text { Lutetian } & 1 \\ \text { Lutetian } & 1 \\ \text { Lutetian } & 1 \\ \text { Lutetian } & 1 \\ \text { Lutetian } & 1 \\ \text { Lutetian } & 1 \\ \text { Lutetian } & 1 \\ \text { Lutetian } & 1\end{array}$


APPENDIX 1 - Continuation.

\begin{tabular}{|c|c|c|c|c|c|}
\hline $\begin{array}{l}\text { Registration } \\
\text { number }\end{array}$ & Collection & $\begin{array}{c}\text { Num. } \\
\text { of } \\
\text { spec. }\end{array}$ & Locality & Stage & $\begin{array}{c}\text { Positive } \\
\text { under UV } \\
\text { light }\end{array}$ \\
\hline B63227 & Museum & 1 & Saint-Félix, Oise, France & Lutetian & 1 \\
\hline B63211 & Morlet & 2 & Saint-Félix, Oise, France & Lutetian & 2 \\
\hline A27587 & Pacaud & 1 & St-Lubin-de-la-Haye, Eure-et-Loir, France & Lutetian & 1 \\
\hline A27783 & Pacaud & 1 & St-Lubin-de-la-Haye, Eure-et-Loir, France & Lutetian & 1 \\
\hline B63243 & $1965-11$ & 6 & Saulxmarchais, Yvelines, France & Lutetian & 6 \\
\hline A28921 & $1965-11$ & 1 & Saulxmarchais, Yvelines, France & Lutetian & 1 \\
\hline A28517 & Bertrant & 1 & Tiverval, Yvelines, France & Lutetian & 1 \\
\hline B63241 & Lhomme & 1 & Vaudancourt, Oise, France & Lutetian & 1 \\
\hline \multicolumn{6}{|c|}{ Bartonian, Paris Basin } \\
\hline A28561 & Pacaud & 7 & Caumont, Seine-et-Marne, France & Bartonian & 6 \\
\hline A28571 & Museum & 2 & Caumont, Seine-et-Marne, France & Bartonian & 2 \\
\hline A28572 & Museum & 2 & Caumont, Seine-et-Marne, France & Bartonian & 2 \\
\hline \multicolumn{6}{|c|}{ Seraphs peterjungi n. sp. } \\
\hline \multicolumn{6}{|c|}{ Lutetian, Paris Basin } \\
\hline A28580 & Museum & 1 & Beynes, Yvelines, France & Lutetian & 1 \\
\hline A28789 & Museum & 1 & Beynes, Yvelines, France & Lutetian & 1 \\
\hline A28506 & Morlet & 1 & Chaussy, Val-d'Oise, France & Lutetian & 1 \\
\hline A28538 & Faullummel & 1 & Chaussy, Val-d'Oise, France & Lutetian & 1 \\
\hline $\mathrm{A} 27613$ & $1965-11$ & 2 & Chaussy, Val-d'Oise, France & Lutetian & 2 \\
\hline A27550 & Schtrock & 1 & Chaussy, Val-d'Oise, France & Lutetian & 1 \\
\hline A28550 & Pacaud & 1 & Chaussy, Val-d'Oise, France & Lutetian & 1 \\
\hline A28559 & Ledon & 1 & Chaussy, Val-d'Oise, France & Lutetian & 1 \\
\hline A28578 & Pacaud & 1 & Chaussy, Val-d'Oise, France & Lutetian & 1 \\
\hline A27273 & Pacaud & 1 & Chaussy, Val-d'Oise, France & Lutetian & 1 \\
\hline A28931 & Pacaud & 1 & Chaussy, Val-d'Oise, France & Lutetian & 1 \\
\hline A28537 & Faullummel & 1 & Chaussy, Val-d'Oise, France & Lutetian & 1 \\
\hline A27634 & Pacaud & 5 & Fercourt, Oise, France & Lutetian & 5 \\
\hline A28512 & Caze & 1 & Grignon, Yvelines, France & Lutetian & 1 \\
\hline A28530 & Ballot ? & 1 & Grignon, Yvelines, France & Lutetian & 1 \\
\hline A27632 & Galerie de Zoologie & 1 & Grignon, Yvelines, France & Lutetian & 1 \\
\hline A11186 & d'Orbigny & 1 & Parnes, Oise, France & Lutetian & 1 \\
\hline A28511 & Roissy & 1 & Parnes, Oise, France & Lutetian & 1 \\
\hline A28521 & Pacaud & 1 & Parnes, Oise, France & Lutetian & 1 \\
\hline A28520 & $1965-11$ & 1 & Saulxmarchais, Yvelines, France & Lutetian & 1 \\
\hline \multicolumn{6}{|c|}{ Diameza (s.s.) fragilis (Defrance, 1825) } \\
\hline \multicolumn{6}{|c|}{ Lutetian, Paris Basin } \\
\hline A27563 & Morlet & 1 & Ferme de l'Orme, Yvelines, France & Lutetian & 0 \\
\hline B63255 & $1965-11$ & 1 & Grignon, Yvelines, France & Lutetian & 1 \\
\hline A27519 & Pacaud & 10 & Villiers-St-Frédéric, Yvelines, France & Lutetian & 7 \\
\hline A27535 & Schtrock & 2 & Villiers-St-Frédéric, Yvelines, France & Lutetian & 2 \\
\hline A27541 & Faullummel & 23 & Villiers-St-Frédéric, Yvelines, France & Lutetian & 17 \\
\hline A28784 & Faullummel & 1 & Villiers-St-Frédéric, Yvelines, France & Lutetian & 1 \\
\hline A28940 & Faullummel & 1 & Villiers-St-Frédéric, Yvelines, France & Lutetian & 1 \\
\hline A28942 & Faullummel & 1 & Villiers-St-Frédéric, Yvelines, France & Lutetian & 1 \\
\hline A28939 & Pacaud & 1 & Villiers-St-Frédéric, Yvelines, France & Lutetian & 1 \\
\hline EM 33124 & Caillat & 1 & Grignon & Lutetian & 1 \\
\hline \multirow{2}{*}{\multicolumn{6}{|c|}{$\begin{array}{l}\text { (Univ. Claude } \\
\text { Bernard Lyon 1) }\end{array}$}} \\
\hline & & & & & \\
\hline \multicolumn{6}{|c|}{ Diameza (Miniseraphs) eratoides (Cossmann, 1889) } \\
\hline \multicolumn{6}{|c|}{ Lutetian, Paris Basin } \\
\hline A28523 & Pacaud & 2 & Chaussy, Val-d'Oise, France & Lutetian & 2 \\
\hline A27534 & Faullummel & 9 & Chaussy, Val-d'Oise, France & Lutetian & 6 \\
\hline A27581 & Pacaud & 7 & Chaussy, Val-d'Oise, France & Lutetian & 6 \\
\hline
\end{tabular}


APPENDIX 1 - Continuation.

\begin{tabular}{|c|c|c|c|c|c|}
\hline $\begin{array}{l}\text { Registration } \\
\text { number }\end{array}$ & Collection & $\begin{array}{l}\text { Num. } \\
\text { of } \\
\text { spec. }\end{array}$ & Locality & Stage & $\begin{array}{c}\text { Positive } \\
\text { under UV } \\
\text { light }\end{array}$ \\
\hline $\mathrm{A} 28785$ & Faullummel & 1 & Chaussy, Val-d'Oise, France & Lutetian & 1 \\
\hline A28932 & Faullummel & 1 & Chaussy, Val-d'Oise, France & Lutetian & 1 \\
\hline A27527 & Pacaud & 13 & Fontenay-en-Vexin, Eure, France & Lutetian & 10 \\
\hline A28933 & Pacaud & 1 & Fontenay-en-Vexin, Eure, France & Lutetian & 1 \\
\hline A28934 & Pacaud & 1 & Fontenay-en-Vexin, Eure, France & Lutetian & 1 \\
\hline B63254 & Lhomme & 1 & Hervelon, Marne, France & Lutetian & 0 \\
\hline \multicolumn{6}{|c|}{ Diameza (Miniseraphs) isabella (Bernay in Deshayes, 1865) } \\
\hline \multicolumn{6}{|c|}{ Lutetian, Paris Basin } \\
\hline A27561 & Pacaud & 1 & Cauvigny, Oise, France & Lutetian & 1 \\
\hline A28783 & Pacaud & 1 & Cauvigny, Oise, France & Lutetian & 1 \\
\hline A28507 & Morlet & 1 & Chaussy, Val-d'Oise, France & Lutetian & 1 \\
\hline A27542 & Pacaud & 7 & Chaussy, Val-d'Oise, France & Lutetian & 7 \\
\hline $\mathrm{B} 63245$ & $1965-11$ & 3 & Chaussy, Val-d'Oise, France & Lutetian & 2 \\
\hline A27543 & Galerie de Zoologie & 2 & Chaussy, Val-d'Oise, France & Lutetian & 2 \\
\hline B72974 & Dolleans & 1 & Chaussy, Val-d'Oise, France & Lutetian & 1 \\
\hline B63244 & Lhomme & 1 & Chaussy, Val-d'Oise, France & Lutetian & 1 \\
\hline A27579 & Faullummel & 41 & Chaussy, Val-d'Oise, France & Lutetian & 34 \\
\hline A28552 & Pacaud & 27 & Chaussy, Val-d'Oise, France & Lutetian & 25 \\
\hline A28556 & Pacaud & 3 & Chaussy, Val-d'Oise, France & Lutetian & 2 \\
\hline A28562 & Faullummel & 4 & Chaussy, Val-d'Oise, France & Lutetian & 3 \\
\hline A27599 & Schtrock & 1 & Chaussy, Val-d'Oise, France & Lutetian & 1 \\
\hline A28564 & Pacaud & 3 & Chaussy, Val-d'Oise, France & Lutetian & 3 \\
\hline A28553 & Pacaud & 1 & Chaussy, Val-d'Oise, France & Lutetian & 1 \\
\hline A28937 & Faullummel & 1 & Chaussy, Val-d'Oise, France & Lutetian & 1 \\
\hline A28935 & Pacaud & 1 & Chaussy, Val-d'Oise, France & Lutetian & 1 \\
\hline A28936 & Pacaud & 1 & Chaussy, Val-d'Oise, France & Lutetian & 1 \\
\hline A28938 & Pacaud & 1 & Chaussy, Val-d'Oise, France & Lutetian & 1 \\
\hline B63248 & $1965-11$ & 1 & Fercourt, Oise, France & Lutetian & 1 \\
\hline $\mathrm{B} 63231$ & Morlet & 1 & Liancourt-Saint-Pierre, Oise, France & Lutetian & 1 \\
\hline B63252 & $1965-11$ & 1 & Liancourt-Saint-Pierre, Oise, France & Lutetian & 1 \\
\hline B63247 & Lhomme & 1 & Mouchy-le-Châtel, Oise, France & Lutetian & 1 \\
\hline A27580 & Pacaud & 6 & Parnes, Oise, France & Lutetian & 6 \\
\hline B63251 & Sarrazin & 3 & Parnes, Oise, France & Lutetian & 3 \\
\hline A28782 & Pacaud & 1 & Parnes, Oise, France & Lutetian & 1 \\
\hline $\mathrm{B} 63250$ & $1965-11$ & 2 & Ponchon, Oise, France & Lutetian & 0 \\
\hline B63253 & $1965-11$ & 2 & Vaudancourt, Oise, France & Lutetian & 1 \\
\hline A27683 & Pacaud & 1 & Vaudancourt, Oise, France & Lutetian & 1 \\
\hline A28582 & Museum & 4 & Villiers-St-Frédéric, Yvelines, France & Lutetian & 4 \\
\hline A28563 & Pacaud & 8 & Bois-Gouët, Loire-Atlantique, France & Bartonian & 8 \\
\hline \multicolumn{6}{|c|}{ Paraseraphs tetanus Jung, 1974} \\
\hline \multicolumn{6}{|c|}{ Ypresian, Paris Basin } \\
\hline B63205 & Lhomme & 2 & Aizy-Jouy, Aisne, France & Ypresian & 2 \\
\hline A28508 & Ferry & 20 & Cuise-Lamotte, Oise, France & Ypresian & 20 \\
\hline $\mathrm{A} 27518$ & Pacaud & 1 & Cuise-Lamotte, Oise, France & Ypresian & 1 \\
\hline A28519 & Museum & 126 & Cuise-Lamotte, Oise, France & Ypresian & 117 \\
\hline A27590 & Roissy & 9 & Cuise-Lamotte, Oise, France & Ypresian & 9 \\
\hline A27597 & Ferry & 8 & Cuise-Lamotte, Oise, France & Ypresian & 8 \\
\hline A27559 & Morlet & 10 & Cuise-Lamotte, Oise, France & Ypresian & 10 \\
\hline A10425 & d'Orbigny & 7 & Cuise-Lamotte, Oise, France & Ypresian & 7 \\
\hline A27555 & Léveque & 2 & Cuise-Lamotte, Oise, France & Ypresian & 2 \\
\hline B63198 & Calas & 3 & Cuise-Lamotte, Oise, France & Ypresian & 3 \\
\hline A28581 & Ferry & 20 & Cuise-Lamotte, Oise, France & Ypresian & 19 \\
\hline A28946 & Museum & 1 & Cuise-Lamotte, Oise, France & Ypresian & 1 \\
\hline A28949 & Museum & 1 & Cuise-Lamotte, Oise, France & Ypresian & 1 \\
\hline A28950 & Museum & 1 & Cuise-Lamotte, Oise, France & Ypresian & 1 \\
\hline
\end{tabular}


APPENDIX 1 - Continuation.

\begin{tabular}{|c|c|c|c|c|c|}
\hline $\begin{array}{l}\text { Registration } \\
\text { number }\end{array}$ & Collection & $\begin{array}{l}\text { Num. } \\
\text { of } \\
\text { spec. }\end{array}$ & Locality & Stage & $\begin{array}{l}\text { Positive } \\
\text { under UV } \\
\text { light }\end{array}$ \\
\hline A28951 & Museum & 1 & Cuise-Lamotte, Oise, France & Ypresian & 1 \\
\hline A28943 & Museum & 1 & Cuise-Lamotte, Oise, France & Ypresian & 1 \\
\hline A28944 & Museum & 1 & Cuise-Lamotte, Oise, France & Ypresian & 1 \\
\hline A28948 & Museum & 1 & Cuise-Lamotte, Oise, France & Ypresian & 1 \\
\hline A28952 & Museum & 1 & Cuise-Lamotte, Oise, France & Ypresian & 1 \\
\hline A28953 & Museum & 1 & Cuise-Lamotte, Oise, France & Ypresian & 1 \\
\hline A28954 & Museum & 1 & Cuise-Lamotte, Oise, France & Ypresian & 1 \\
\hline A28955 & Museum & 1 & Cuise-Lamotte, Oise, France & Ypresian & 1 \\
\hline A28957 & Museum & 1 & Cuise-Lamotte, Oise, France & Ypresian & 1 \\
\hline A28787 & Ferry & 1 & Cuise-Lamotte, Oise, France & Ypresian & 1 \\
\hline A29224 & Ferry & 1 & Cuise-Lamotte, Oise, France & Ypresian & 1 \\
\hline A27528 & Pacaud & 5 & Monampteuil, Aisne, France & Ypresian & 5 \\
\hline A27602 & Faullummel & 47 & Saint-Gobain, Aisne, France & Ypresian & 43 \\
\hline A28545 & Museum & 2 & Saint-Gobain, Aisne, France & Ypresian & 2 \\
\hline A27547 & Galerie de Zoologie & 7 & Saint-Gobain, Aisne, France & Ypresian & 7 \\
\hline A27549 & Schtrock & 1 & Saint-Gobain, Aisne, France & Ypresian & 0 \\
\hline A27539 & Pacaud & 30 & Saint-Gobain, Aisne, France & Ypresian & 30 \\
\hline A28579 & Faullummel & 1 & Saint-Gobain, Aisne, France & Ypresian & 1 \\
\hline A28956 & Faullummel & 1 & Saint-Gobain, Aisne, France & Ypresian & 1 \\
\hline A28958 & Faullummel & 1 & Saint-Gobain, Aisne, France & Ypresian & 1 \\
\hline A28959 & Faullummel & 1 & Saint-Gobain, Aisne, France & Ypresian & 1 \\
\hline A27531 & Pacaud & 1 & Gan, Pyrénées-Atlantiques, France & Ypresian & 1 \\
\hline \multicolumn{6}{|c|}{ Paraseraphs placitus Jung, 1974} \\
\hline \multicolumn{6}{|c|}{ Lutetian, Paris Basin } \\
\hline A27521 & Pacaud & 1 & Châteaurouge, Oise, France & Lutetian & 1 \\
\hline A27532 & Pacaud & 8 & Chaussy, Val-d'Oise, France & Lutetian & 8 \\
\hline B63212 & Boule & 2 & Chaussy, Val-d'Oise, France & Lutetian & 2 \\
\hline B70331 & Morlet & 6 & Chaussy, Val-d'Oise, France & Lutetian & 6 \\
\hline B63240 & Lhomme & 4 & Chaussy, Val-d'Oise, France & Lutetian & 3 \\
\hline A27611 & Galerie de Zoologie & 1 & Chaussy, Val-d'Oise, France & Lutetian & 1 \\
\hline A28554 & Pacaud & 1 & Chaussy, Val-d'Oise, France & Lutetian & 0 \\
\hline IM 544 & Houdas & 8 & Chaussy, Val-d'Oise, France & Lutetian & 8 \\
\hline A28966 & Boule & 1 & Chaussy, Val-d'Oise, France & Lutetian & 1 \\
\hline A27594 & Pacaud & 2 & Fercourt, Oise, France & Lutetian & 1 \\
\hline A28961 & Pacaud & 1 & Fercourt, Oise, France & Lutetian & 1 \\
\hline A28962 & Pacaud & 1 & Fercourt, Oise, France & Lutetian & 1 \\
\hline A27533 & Pacaud & 2 & Fontenay-en-Vexin, Eure, France & Lutetian & 2 \\
\hline A27566 & Pacaud & 1 & Fontenay-en-Vexin, Eure, France & Lutetian & 1 \\
\hline A28525 & Museum & 9 & Grignon, Yvelines, France & Lutetian & 5 \\
\hline A28531 & Ballot & 3 & Grignon, Yvelines, France & Lutetian & 3 \\
\hline A28963 & Ballot & 1 & Grignon, Yvelines, France & Lutetian & 1 \\
\hline A28964 & Ballot & 1 & Grignon, Yvelines, France & Lutetian & 1 \\
\hline A28533 & Museum & 1 & Parnes, Oise, France & Lutetian & 1 \\
\hline A27536 & Pacaud & 5 & Parnes, Oise, France & Lutetian & 5 \\
\hline A27537 & Galerie de Zoologie & 4 & Parnes, Oise, France & Lutetian & 3 \\
\hline B63209 & Sarazin & 3 & Parnes, Oise, France & Lutetian & 3 \\
\hline B63208 & Morlet & 1 & Parnes, Oise, France & Lutetian & 1 \\
\hline A28960 & Pacaud & 1 & Parnes, Oise, France & Lutetian & 1 \\
\hline B63206 & & 1 & Ponchon, Oise, France & Lutetian & 1 \\
\hline \multicolumn{6}{|c|}{ Bartonian, Paris Basin } \\
\hline A27522 & Pacaud & 3 & Baron, Oise, France & Bartonian & 1 \\
\hline A28965 & Faullummel & 1 & Baron, Oise, France & Bartonian & 1 \\
\hline A27553 & Galerie de Zoologie & 2 & Caumont, Seine-et-Marne, France & Bartonian & 2 \\
\hline A27525 & Pacaud & 1 & Le Guépelle, Val-d'Oise, France & Bartonian & 0 \\
\hline
\end{tabular}


APPENDIX 1 - Continuation.

\begin{tabular}{|c|c|c|c|c|c|}
\hline $\begin{array}{l}\text { Registration } \\
\text { number }\end{array}$ & Collection & $\begin{array}{c}\text { Num. } \\
\text { of } \\
\text { spec. }\end{array}$ & Locality & Stage & $\begin{array}{c}\text { Positive } \\
\text { under UV } \\
\text { light }\end{array}$ \\
\hline \multicolumn{6}{|c|}{ Paraseraphs armoricus (Vasseur, 1882) } \\
\hline \multicolumn{6}{|c|}{ Bartonian, Loire-Atlantique } \\
\hline J09267 & Hébert & 1 & Arthon, Loire-Atlantique, France & Bartonian & $x$ \\
\hline A27530 & Pacaud & 2 & Bois-Gouët, Loire-Atlantique, France & Bartonian & 2 \\
\hline A28788 & Pacaud & 1 & Bois-Gouët, Loire-Atlantique, France & Bartonian & 1 \\
\hline no & Morlet & 1 & $?$ & Bartonian? & 1 \\
\hline \multicolumn{6}{|c|}{ Bartonian, Aquitan Basin } \\
\hline A28397 & Ledon & 4 & Blaye, Gironde, France & Bartonian & $x$ \\
\hline \multicolumn{6}{|c|}{ Paraseraphs praecedens n. sp. } \\
\hline \multicolumn{6}{|c|}{ Thanetian, Paris Basin } \\
\hline A05707 & Pacaud & 1 & Abbecourt, Oise, France & Thanetian & 0 \\
\hline
\end{tabular}

\section{APPENDIX 2}

List of the Recent material: Terebellum terebellum (Linnaeus, 1758) from South East Pacific.

\begin{tabular}{|c|c|c|}
\hline Coll. Malacologie, MNHN & Num. of spec. & Locality \\
\hline 24 (nebulosum, punctulorum) & 4 & New Caledonia \\
\hline 27 (nebulosum, punctulorum) & 5 & New Caledonia \\
\hline 19 (punctulorum) & 4 & Atoll de Surprise (New Caledonia) \\
\hline 37 & 1 & Atoll de Surprise (New Caledonia) \\
\hline 39 (nebulosum) & 1 & Atoll de Surprise (New Caledonia) \\
\hline 37 & 1 & Atoll de Surprise (New Caledonia) \\
\hline 10 (punctulorum) & 2 & Baie de St Vincent (New Caledonia) \\
\hline 12 (punctulorum) & 1 & Baie de St Vincent (New Caledonia) \\
\hline 11 & 2 & Grand Récif Sud (New Caledonia) \\
\hline 15 (puntulorum, nebulosum) & 2 & Grand Récif Sud (New Caledonia) \\
\hline 21 (punctulorum) & 9 & Grand Récif Sud (New Caledonia) \\
\hline 36 (punctulorum) & 3 & Grand Récif Sud (New Caledonia) \\
\hline 38 (punctulorum) & 2 & Grand Récif Sud (New Caledonia) \\
\hline 53 (delicatum) & 1 & Grand Récif Sud (New Caledonia) \\
\hline 11 (punctulorum) & 1 & Grand Récif Sud (New Caledonia) \\
\hline 16 (punctulorum) & 1 & Grand Récif Sud (New Caledonia) \\
\hline 21 & 1 & Grand Récif Sud (New Caledonia) \\
\hline 34 & 1 & Grand Récif Sud (New Caledonia) \\
\hline 18 (punctulorum) & 5 & Île des Pins (New Caledonia) \\
\hline 17 (punctulorum) & 4 & Île Ouen-Baie du Prony (New Caledonia) \\
\hline 9 (punctulorum) & 3 & Lagon Nord (New Caledonia) \\
\hline 13 & 1 & Lagon Nord (New Caledonia) \\
\hline 35 (lineatum) & 2 & Lagon Nord (New Caledonia) \\
\hline 35 (punctulorum) & 1 & Lagon Nord (New Caledonia) \\
\hline 52 (punctulorum, nebulosum) & 5 & New Caledonia \\
\hline 32 (nebulosum) & 2 & Balabio (New Caledonia) \\
\hline 1 (punctulorum) & 1 & Balabio (New Caledonia) \\
\hline 6 (nebulosum) & 2 & Canala (New Caledonia) \\
\hline 14 (punctulorum) & 3 & Nouméa (New Caledonia) \\
\hline 40 (lineatum) & 6 & Nouméa (New Caledonia) \\
\hline 23 & 1 & Nouméa (Baie des Citrons) (New Caledonia) \\
\hline 31 (nebulosum, punctulorum) & 6 & Nouméa (Quatre bancs de l'Ouest) (New Caledonia) \\
\hline 31 (nebulosum) & 1 & Nouméa (Quatre bancs de l'Ouest) (New Caledonia) \\
\hline
\end{tabular}


APPENDIX 2 - Continuation.

\begin{tabular}{|c|c|c|}
\hline Coll. Malacologie, MNHN & Num. of spec. & Locality \\
\hline 28 (punctulorum) & 3 & Poindimié (New Caledonia) \\
\hline 59 (nebulosum) & 4 & Poindimié (New Caledonia) \\
\hline 22 (punctulorum) & 1 & Poum (New Caledonia) \\
\hline 25 (lineatum, nebulosum, punctulorum) & 3 & Poum (New Caledonia) \\
\hline 26 (lineatum, nebulosum) & 6 & Poum (New Caledonia) \\
\hline 29 (punctulorum) & 1 & Poum (New Caledonia) \\
\hline 41 (punctulorum, nebulosum) & 3 & Poum (New Caledonia) \\
\hline 58 (delicatum, lineatum) & 6 & Poum (New Caledonia) \\
\hline 8 (nebulosum, punctulorum?) & 2 & Thio (New Caledonia) \\
\hline 5 (nebulosum, lineatum) & 21 & Yaté (New Caledonia) \\
\hline 30 (delicatum) & 2 & Belep (New Caledonia) \\
\hline 54 (punctulorum, nebulosum) & 4 & New Caledonia \\
\hline 56 (punctulorum, nebulosum) & 4 & New Caledonia \\
\hline 2 (lineatum) & 1 & New Caledonia \\
\hline 55 (punctulorum, nebulosum) & 3 & Andaman? (Inde) \\
\hline 20 (nebulosum) & 1 & Seychelles \\
\hline 49 (punctulorum) & 1 & Aoré Island (Aimbuei Bay) (Vanuatu) \\
\hline 51 (nebulosum) & 1 & Baldwin Bay (Vanuatu) \\
\hline 42 (nebulosum) & 1 & Belmoul Lagoon (Vanuatu) \\
\hline 44 (nebulosum) & 1 & Palikulo Bay (Vanuatu) \\
\hline 45 (nebulosum) & 2 & SE corner of Santo (Vanuatu) \\
\hline 46 (delicatum) & 1 & Segond Channel (Vanuatu) \\
\hline 43 (punctulorum) & 1 & Tangoa Island (Vanuatu) \\
\hline 48 (nebulosum) & 2 & Tutuba Island (Vanuatu) \\
\hline 47 (nebulosum) & 1 & W Aésé Island (Vanuatu) \\
\hline 47 (nebulosum) & 1 & W Aésé Island (Vanuatu) \\
\hline 50 (delicatum) & 2 & W Tangoa Island (Vanuatu) \\
\hline 57 (nebulosum, lineatum) & 15 & Plateau des Chesterfield \\
\hline 3 (nebulosum) & 1 & Plateau des Chesterfield \\
\hline 3 (nebulosum) & 1 & Plateau des Chesterfield \\
\hline 3 & 1 & Plateau des Chesterfield \\
\hline 3 (nebulosum) & 11 & Plateau des Chesterfield \\
\hline 4 (nebulosum) & 7 & Plateau des Chesterfield \\
\hline 7 (nebulosum) & 3 & Plateau des Chesterfield \\
\hline 33 (lineatum) & 1 & $?$ \\
\hline
\end{tabular}

